
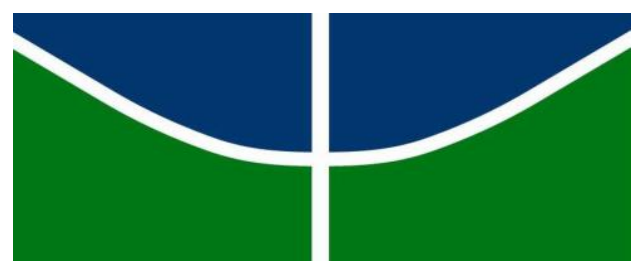

Universidade de Brasîlia - UnB

Faculdade de Direito - FD

Dissertação de Mestrado

Área de Concentração: Direito, Estado e Constituição

SEM PORTA-VOZ NA RUA, SEM DONO EM CASA: AS LUTAS DO

MOVIMENTO DE MULHERES CAMPONESAS (MMC BRASIL) PELO

DIREITO A UMA VIDA SEM VIOLÊNCIA

DIANA MELO PEREIRA

Brasilia, 2015. 
Universidade de Brasilia - UnB

Faculdade de Direito - FD

Dissertação de Mestrado

Área de Concentração: Direito, Estado e Constituição

\section{SEM PORTA-VOZ NA RUA, SEM DONO EM CASA: AS LUTAS DO \\ MOVIMENTO DE MULHERES CAMPONESAS (MMC BRASIL) PELO \\ DIREITO A UMA VIDA SEM VIOLÊNCIA}

\section{DIANA MELO PEREIRA}

Dissertação apresentada ao Programa de PósGraduação em Direito como pré-requisito à obtenção do título de Mestre em Direito.

Área de Concentração: Direito, Estado e Constituição.

Linha de Pesquisa: O Direito Achado na Rua.

Orientador: Prof. Dr. Alexandre Bernardino Costa.

Brasilia, 2015. 


\section{CESSÃO DE DIREITOS}

É concedida à Universidade de Brasîlia permissão para reproduzir cópias desta dissertação de mestrado e para emprestar ou vender tais cópias somente para propósitos acadêmicos e científicos. A autora reserva outros direitos de publicação e nenhuma parte desta dissertação de mestrado pode ser reproduzida sem autorização por escrito da autora.

\section{AUTORA: Diana Melo Pereira}

TÍTULO: Sem porta-voz na rua, sem dono em casa: as lutas do Movimento de Mulheres Camponesas (MMC Brasil) pelo direito a uma vida sem violência

ANO: 2015

\section{REFERÊNCIA BIBLIOGRÁFICA}

PEREIRA, Diana Melo. Sem porta-voz na rua, sem dono em casa: as lutas do Movimento de Mulheres Camponesas (MMC Brasil) pelo direito a uma vida sem violência. 2015. $157 \mathrm{f}$. Dissertação (Mestrado em Direito) - Universidade de Brasilia, Brasîlia, 2015.

\section{FICHA CATALOGRÁFICA}

Ficha catalográfica elaborada automaticamente, com os dados fornecidos pelo(a) autor(a)

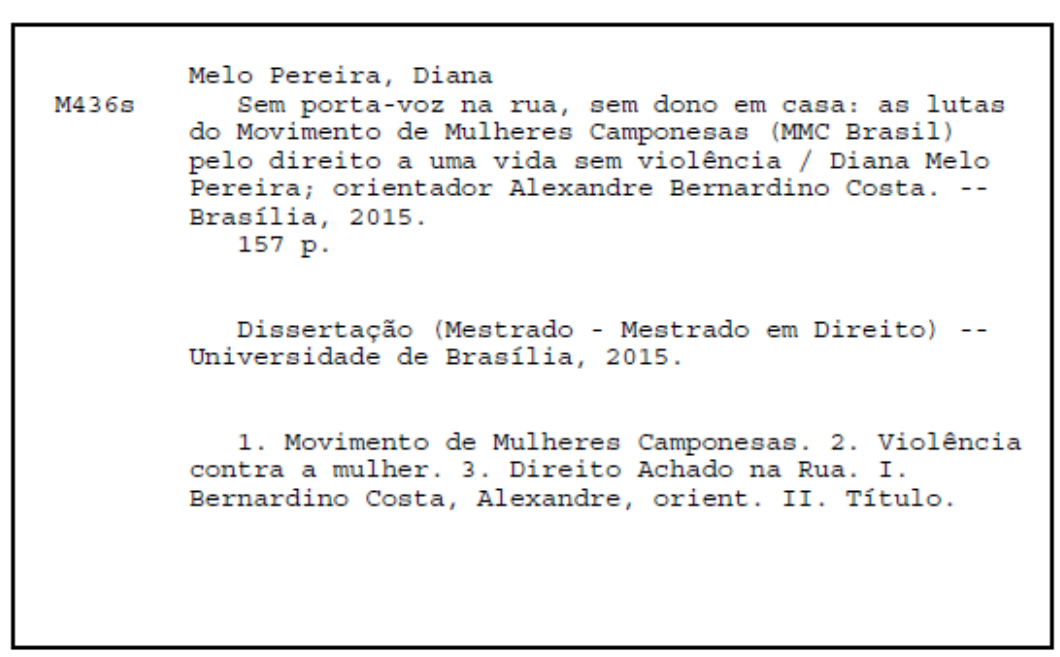


Universidade de Brasilia - UnB

Faculdade de Direito - FD

Dissertação de Mestrado

Sem porta-voz na rua, sem dono em casa: as lutas do Movimento de Mulheres Camponesas (MMC Brasil) pelo direito a uma vida sem violência

\section{Diana Melo Pereira}

Dissertação submetida ao Programa de Pós-Graduação em Direito da Universidade de Brasília como parte dos requisitos necessários para a obtenção do grau de Mestre em Direito.

Área de Concentração: Direito, Estado e Constituição.

\section{APROVADA POR:}

Prof. Dr. Alexandre Bernardino Costa. (FD/UnB)

(Presidente)

Profa. Dra. Bistra Stefanova Apostolova. (FD/UnB)

(Examinadora Interna - Titular)

Profa. Dra. Fabiana Cristina Severi. (FD/Ribeirão Preto/USP)

(Examinadora Externa - Titular)

Profa. Dra. Camilla Cardoso de Mello Prando. (FD/UnB)

(Suplente)

Brasilia, 10 de abril de 2015. 
A todas as mulheres que são mães solteiras ou, mesmo casadas, estão sobrecarregadas pela divisão sexual do trabalho e se atrevem a sonhar.

Ao Movimento de Mulheres Camponesas.

Ao meu filho João Francisco, pelo nosso futuro. 


\section{AGRADECIMENTOS}

Agradeço, em primeiro lugar, à minha mãe, Marylene de Araújo Melo, e aos irmãos de sangue, Lawrence Melo Pereira e Vinicius Melo Pereira, e de coração, Jonata Carvalho Galvão da Silva, que sabem o quanto eu sonhei, lutei e persisti para conseguir fazer o mestrado em outro Estado, mesmo depois de ter engravidado sozinha no primeiro semestre do curso. Agradeço por terem acreditado em mim, torcido e me apoiado concretamente durante esse processo que se deu em muito mais tempo do que este período em que estou formalmente no Programa de Pós-Graduação.

Agradeço ao meu orientador, Alexandre Bernardino Costa, pelo apoio e orientação durante todo o processo. Agradeço pela paciência, incentivo e aposta neste trabalho.

Agradeço às professoras Fabiana Severi e Bistra Apostolova, que foram muito mais do que avaliadoras deste trabalho, mas fazem parte da minha caminhada acadêmica e militante como feminista atuando em projetos de extensão popular.

Agradeço imensamente a todas às amigas e aos amigos que compartilharam o cuidado com o meu filho, João Francisco, para que eu pudesse escrever a dissertação: Laise Cabral, Lucas Cacau, Juliana Cézar Nunes, Clara Fagundes, Juliana Moura, Luciana Moura, Tiago Martins, Juliana Lopes, Myllena Calasans e Aline Couto.

Agradeço às companheiras e aos companheiros da Sociedade Maranhense de Direitos Humanos (SMDH), Escritório Brasîlia, por toda a compreensão em adequação de horários e rotina de trabalho, principalmente à Joisiane Gamba, Veridiana Araújo, Adriana Costa e Dália Almeida, e por toda a torcida e incentivo durante todo o processo de escrita. Da mesma forma, agradeço à toda a equipe que hoje está no Curso de Extensão a Distância, em especial, à Aline Maia.

Agradeço aos companheiros Diego Diehl e Humberto Góes, pela parceria firmada durante todo o período em Brasilia. Meus cúmplices na militância e na vida.

Agradeço a todas às mulheres e aos poucos homens que pertencem ao Coletivo Marieta Baderna da Rede Nacional de Advogadas e Advogados Populares - RENAAP, da Coluna Direito das Marias do Blogue da Assessoria Jurídica Popular, do Grupo de Trabalho de Direito e Relações de Gênero e Sexualidade, das Promotoras Legais Populares, da Consulta Popular e 
do Projeto "Maria da Penha", que contribuíram com as inquietações, dúvidas e reflexões que me levaram a escrever estas páginas.

Agradeço às professoras Alejandra Pascoal, Lourdes Bandeira e Marisa Correa, pelos preciosos ensinamentos e facilitação de debates nas disciplinas de Sociologia Jurídica e Pensamento Social e Relações de Gênero, bem como a todas às pessoas que estiveram comigo nesses caminhos.

Agradeço às companheiras e aos companheiros do Grupo do Direito Achado na Rua, bem como ao professor Zé Geraldo de Sousa Júnior, pelo trabalho acadêmico e militância desempenhados no grupo. Também, ao Projeto de Extensão AJUP Roberto Lyra Filho, pelas reflexões sobre um direito para os oprimidos e as oprimidas.

Agradeço à Lívia Gimenes, ao Dimitri Graco e ao Luciano Nascimento, que não me deixaram desistir frente aos desafios finais na elaboração deste trabalho. Em especial, a este último, por ter me acolhido quando eu não tinha onde estudar e me suportado com todas as tensões, estresse, cansaço e nervosismo.

Agradeço à Sílvia Almeida, que foi muito mais que uma revisora, foi uma incentivadora e uma companheira que não me deixou fraquejar nos últimos momentos. 


\section{Aninha e suas pedras}

Não te deixes destruir... Ajuntando novas pedras e construindo novos poemas.

Recria tua vida, sempre, sempre. Remove pedras e planta roseiras e faz doces. Recomeça.

Faz de tua vida mesquinha um poema. E viverás no coração dos jovens e na memória das gerações que hão de vir.

Estafonte é para uso de todos os sedentos. Toma a tua parte. Vem a estas páginas e não entraves seu uso aos que têm sede.

(Cora Coralina) 


\section{RESUMO}

Ao contrário do que vem sendo comumente trabalhado a respeito da temática da violência contra a mulher, o Movimento de Mulheres Camponesas (MMC Brasil), tem trabalhado uma visão mais ampla sobre a percepção da questão: tem defendido a necessidade do relacionamento entre opressões de sexo e classe social, no que diz respeito ao enfrentamento à violência. Compreendendo as ligações entre capitalismo e patriarcado, desenham sua atuação na luta pelo direito a uma vida sem violência para as mulheres no campo, de forma articulada, combatendo a ambos. Questionam o modo de produção capitalista no campo, em especial, o agronegócio e uso de agrotóxicos e transgênicos, refletindo o quanto esse modelo está articulado com o patriarcado, oprimindo as mulheres e impedindo uma possibilidade de libertação de todas e todos. A partir da teoria feminista, questionamos quem é a camponesa e a nova mulher que o movimento propõe. Com apoio nas teorias materialistas que discutem a divisão sexual do trabalho e a coextensividade das relações de classe e sexo, discutimos a respeito das relações entre capitalismo e patriarcado. Finalmente, a partir da teoria de Lyra Filho da dialética social do Direito, trabalhamos o surgimento e as lutas do Movimento de Mulheres Camponesas (MMC Brasil), em principal, suas ações em tensionamento ao sistema para transformação do direito estatal, a partir de sua compreensão sobre o que é violência contra as mulheres.

Palavras-chave: Movimento de Mulheres Camponesas, violência contra a mulher, $O$ Direito Achado na Rua. 


\begin{abstract}
Contrary to the common approach to the subject of violence against women, the movement of peasant women (Movimento de Mulheres Camponesas) - MMC Brasil takes the issue from a much open view: it defends the need for the comprehension of the relationship between sexual and social class oppressions when confronting violence. By understanding the relationship between capitalism and patriarchal society, the movement bases its action for a life without violence for rural women on articulately combating both of them. It questions the capitalist way of production in the land, with emphasis on the use of agricultural toxicants and genetic modified organisms, reflecting on to what extend this model articulates with patriarchy, oppresses women and closes the possibilities for the liberation of both women and men. From the perspective of the feminist theory, we question who is the peasant woman, and who is the new woman the movement proposes. Under the light of the materialistic theories that discuss the sexual division of labor and the co-extension of the relationship between class and sex, we discuss on the relationship between capitalism and patriarchy. Finally, from Lyra Filho's dialectical theory of Law, we discuss the development and fights of MMC Brasil, specially its actions in confrontation to the system for a change in the State law, through its comprehension of what violence against women is.
\end{abstract}

Keywords: Women Peasent Movement, violence against women, "law found in the streets". 


\section{Sumário}

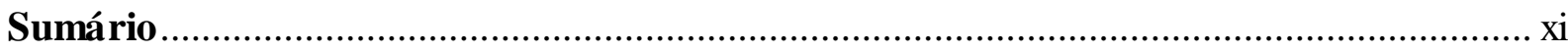

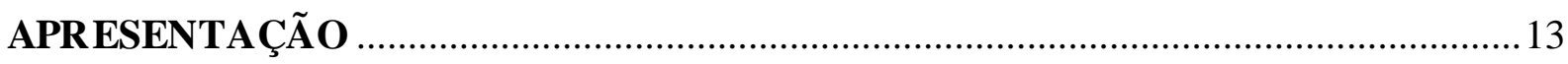

De onde eu vim e por onde andei: a minha posição no mundo e como surge o tema ..........13

Trilhando o caminho: o mapa e os óculos usados, ou o método............................................ 17

Dos óculos à escolha do destino: por que essa trilha e essa paisagem ................................22

Lyra, meu amigo: diálogos com Roberto Lyra Filho sobre as lutas do Movimento de Mulheres

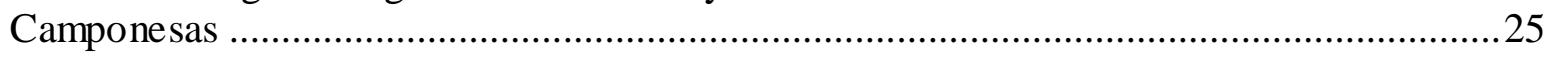

CAPÍTULO 1: FEMINISMO CAMPONÊS E AS DINÂMICAS DA IDENTIDADE NA COMPREENSÃO DA VIOLÊNCIA CONTRA A MULHER .......................................27

1.1 Mulher, mulheres: quem é ela, quem são elas? .........................................................2

1.2 Feminismo camponês e a construção de uma "nova mulher" ....................................... 34

1.2.1 Contribuição das chamadas pós-estruturalistas à análise .........................................36

1.2.2 O não essencialismo pela visão de uma das materialistas francófonas: uma crítica ao

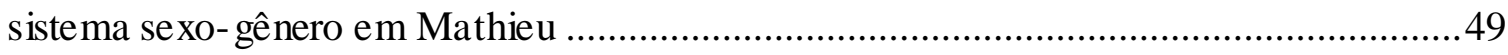

CAPÍTULO 2: MULHER CAMPONESA E DIVISÃO SEXUAL DO TRABALHO: PATRIARCADO E CAPITALISMO NO CAMPO.

2.1 Sexagem e as mulheres enquanto classe: a apropriação como categoria para releitura da

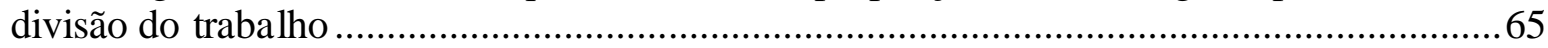

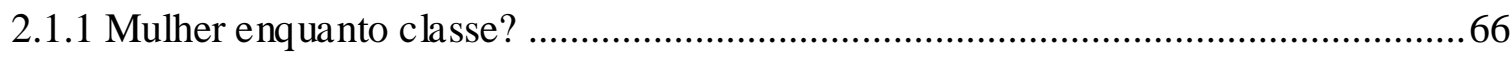

2.1.2 Meios utilizados para manter as mulheres, enquanto classe, em situação de

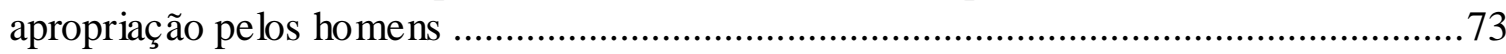

2.2 "Patriarcado e Capitalismo" ou "Sexo com Classe": uma leitura a partir da Divisão Sexual do Trabalho e a consubstancialidade das relações sociais

CAPÍTULO 3: "QUANDO UMA MULHER AVANÇA, NENHUM HOMEM RETROCEDE"? CONVENCENDO A SOCIEDADE E OS PRÓPRIOS MOVIMENTOS DO CAMPO SOBRE O DIREITO A UMA VIDA SEM VIOLENCIA PARA AS CAMPONESAS . .91

3.1 O que é Direito? Releituras de Roberto Lyra Filho a partir do feminismo .....................92

3.2 Mulheres Camponesas: classe ou grupo social? Por uma perspectiva de consubstancialidade das relações no Direito .....................................................................95

3.3 A Dialética Social do Direito e as relações de sexo e classe no campo no Brasil ........ 101

3.3.1 Breves notas sobre a crítica de Lyra Filho às ideologias jurídicas ........................ 101

3.3.2 O Direito não se limita a aspecto interno do processo histórico. Ele tem raiz

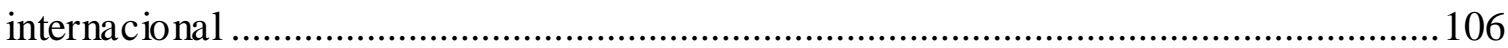

3.3.3 Lutas de Classes e Grupos no Campo Brasileiro ............................................... 115

3.3.4 Luta por direitos: espaços institucionais e a atividade anômica organizada ........... 138 
CONSIDERAÇÕES FINAIS

145

REFERÊNCIAS BIBLIOGRÁFICAS 


\section{APRESENTAÇÃO}

\section{De onde eu vim e por onde andei: a minha posição no mundo e como surge o tema}

Como mote para a apresentação deste trabalho, destacarei nas próximas linhas as motivações acadêmicas e parte das motivações políticas que me trouxeram ao tema desta dissertação.

Acredito que pode ser também de grande valia a quem ler este trabalho entender quais os sentimentos que estiveram em mim quando eu fiz essa escolha. Deter-me nesse ponto destaca uma posição epistemológica que se coaduna com o método escolhido de não acreditar em um conhecimento neutro, isto é, produzido sem qualquer relação com a própria vivência e escolhas políticas.

Como pode ser observado, esta apresentação será escrita na primeira pessoa do singular, assim como a conclusão, visto que é o ponto mais pessoal de todo texto e poderá situar o leitor sobre quem é esta pesquisadora que escreve sobre um construído fora de sua própria realidade. Não sou camponesa, não integro ainda o Movimento de Mulheres Camponesas (MMC), embora sejam de meu interesse futuras colaborações de forma mais orgânica.

No entanto, por outro lado, assumo que o texto também tem um quê de autobiográfico, porque sou mulher e, como tal, já sofri e sofro formas de violência. Haverá, portanto, pontos de encontro entre o que será o "objeto" de análise do trabalho e a minha própria vivência. De forma clara, posso destacar o meu lugar no mundo e possibilitar ao leitor a compreensão de onde eu falo, e é isto o que farei agora.

Venho de família classe média, sou filha de funcionários públicos que se separaram quando eu ainda era muito pequena, antes mesmo de eu completar um ano. Quanto aos meus avós: pelo lado materno, sou neta de um professor, jornalista e advogado e de uma "dona de casa"; pelo lado paterno, não tenho tantas informações, mas pelo que pude entender, meu avô trabalhava na própria terra e a minha avó morreu cedo. O meu avô paterno se casou novamente com uma mulher que também assumia "somente" as tarefas domésticas. O machismo, tanto de um lado como de outro, era muito forte e se manifestava no que dizia respeito a um padrão 
moral esperado de uma "mocinha" de classe média, mas com a abertura que acabava sendo proporcionada com o incentivo ao estudo e independência financeira.

O fato de a minha mãe ter tido a coragem de se separar do meu pai quando eu e meus dois irmãos ainda éramos crianças, e toda a própria luta que ela desenvolveu para ser ela mesma, muitas vezes fora do esperado em uma capital provinciana como São Luís do Maranhão, cidade que sempre tendeu a moldar as mulheres dentro de um formato pré-estabelecido, também me marcou bastante. Mostrou-me que era possível ser quem eu quisesse ser.

Desta forma, o que me despertou em relação ao feminismo foi o que acaba por mexer com muitas meninas brancas que seguem o mesmo padrão que o meu: a busca por liberdade e a fuga da obrigatoriedade da dupla jornada de trabalho.

Nossas famílias querem "estudar" suas filhas, querem que sejam independentes, mas... nem tanto; porque nos querem mantidas dentro de um padrão de comportamento: o da mulher que se casa, que tem filhos e um bom emprego, assumindo dupla ou tripla jornada de trabalho, dividindo-se entre a vida profissional e o cuidado dos filhos, do marido e dos parentes doentes, com o "apoio" de mulheres mais negras e pobres que a assistem como "domésticas".

Em última instância, tendem a "treinar" a nós, as suas filhas "mocinhas", para assumir essas tarefas e o futuro gerenciamento das empregadas domésticas, esperando que nos comportemos dentro de um padrão de respeitabilidade, o que implica um modo de falar, vestir, ser e conviver.

Devemos ser delicadas e submissas e nos distinguir de toda forma de "mulheres da vida", de "vadias". Devemos nos distinguir das mulheres mais pobres também. Isso implica estar dentro de um status e dos seus custos com lojas, terapias estéticas, salões de beleza, criando-se, assim, uma "consciência de classe" que nos distingue das trabalhadoras domésticas, "nossas serviçais".

Não é à toa que algumas moças da minha geração se insurgiram contra esse modelo e criaram, integraram e levaram à frente o movimento conhecido como "Marchas das Vadias" mundo afora, porque essa era a demanda de suas vidas. Lançamo-nos a uma luta individual quando percebemos que nunca estaremos dentro do padrão; nem nós, nem nenhuma mulher, porque o padrão é produzido mesmo para ser constantemente perseguido, mas nunca alcançado.

A luta individual no seio de nossas famílias acaba sendo coletivizada quando percebemos que outras, como nós, passam pelos mesmos problemas. Algumas, como eu, se 
interessam pela questão a tal ponto que a transformam em objeto de estudo. No afã de entendermos onde estamos, colocamos a nós mesmas como problema. Mas, nos lançando à luta no espaço público e na academia, acabamos por nos confrontar com outros grupos de mulheres. São negras, índias, trabalhadoras domésticas, lésbicas, transexuais... que nos questionam e nos confrontam, lembrando que nós falamos não por todas as mulheres, mas falamos a partir de nossa classe social e cor. Desta maneira, podemos perceber que, dentre as mulheres, há quem esteja em posições privilegiadas. Também percebi que havia uma questão forte de raça e etnia, classe e sexualidade que deveria ser entendida e considerada, e que havia "as" mulheres, não "a" mulher. Essa trajetória cria a ambiência para a curiosidade e o desenvolvimento de parte das ideias que se seguirão.

Mas a opção pelo tema ainda está carregada de outros traços biográficos que situam o porquê da escolha de um movimento social organizado como mote para a pesquisa.

Desde o início do curso de Direito na Universidade Federal do Maranhão (UFMA), fiz uma opção política pelos "esfarrapados do mundo", como diria Paulo Freire. A partir da extensão popular conhecida como Assessoria Jurídica Universitária Popular (AJUP), entrei em contato desde cedo com as demandas e lutas por direitos de grupos organizados populares (os chamados movimentos sociais), principalmente o direito à terra. Tive como marcos teóricos essenciais para a realização desse trabalho autores como Paulo Freire e Roberto Lyra Filho, e pude me aproximar teoricamente da linha de pesquisa "O Direito Achado na Rua", o que me trouxe, por sua vez, até a Universidade de Brasîlia (UnB), com o objetivo de cursar pósgraduação e aprofundar a práxis ao lado dos movimentos.

Nesses primeiros trabalhos como extensionista, no entanto, não tinha tido ainda oportunidade de relacionar a militância feminista própria como temática de trabalho na assessoria jurídica popular. Isso mudaria com a chegada à Universidade de Brasilia.

$\mathrm{Na}$ UnB, pude finalmente articular a própria militância feminista com a ação extensionista, a partir dos projetos "Direitos Humanos e Gênero: Formação de Promotoras Legais Populares" e "Atendimento a Mulheres em Situação de Violência Doméstica e Familiar", mais conhecido como "Projeto Maria da Penha". Ainda assim, no entanto, não conseguia enfrentar, de modo mais direto e claro, questões populares relacionadas à classe (como dantes realizava com a militância no direito à terra e moradia) com a questão das mulheres. 
A extensão não me possibilitava isso até aquele momento, mas, por outro lado, a advocacia popular reabriu essa primeira porta. Pude participar de espaços de militância nessas áreas como advogada popular e observei, gradativamente, dentro dos movimentos sociais, como as mulheres e outros grupos foram conseguindo pautar as ditas questões de gênero, raça e sexualidade, ao lado das questões de classe.

Afirmavam, pois, que uma proposta libertadora não poderia manter outras opressões, fortalecendo, cada vez mais, falas como "Quando uma mulher avança, nenhum homem retrocede" ou "Sem feminismo, não há socialismo". Dentre esses grupos, o Movimento de Mulheres Camponesas me chamou atenção e percebi o quanto os outros movimentos de luta pela terra respeitavam a presença de um movimento só de mulheres em meio aos outros movimentos mistos.

O contato específico com a demanda da violência contra a mulher no campo aconteceu em meio a atividades de assessoria jurídica popular, já como advogada, em apoio a atividades do Movimento dos Trabalhadores Rurais Sem Terra (MST) e da Via Campesina, em 2012.

Como as lideranças dos movimentos sabiam que eu já tinha passado por experiência como advogada voluntária de projeto de atendimento a mulheres em situação de violência doméstica e familiar e que atuava na formação de Promotoras Legais Populares (PLPs), passaram a me pedir referências sobre como agir em relação a situações de violência com as mulheres dos movimentos. O Movimento dos Trabalhadores Desempregados (MTD), que tem, no Distrito Federal (DF), viés "rururbano", com um acampamento em área rural em Sobradinho, chegou mesmo a demandar, por exemplo, a formação de uma turma específica de PLPs no acampamento.

A experiência de formação de PLPs com a base do acampamento não foi muito vitoriosa por vários motivos que, por si só, dariam vazão a um estudo específico (tarefa que deverei cumprir em seguida a este trabalho). Mas o que cabe mencionar aqui é que as dificuldades enfrentadas me levaram a perceber que existia uma diferenciação entre o enfrentamento à violência contra a mulher na cidade e no espaço rural. Mesmo em casos como o do acampamento do MTD, por mais que esses espaços fossem próximos, havia diferenças cultura is e mesmo logísticas para a saída da situação de violência que mereciam ser melhor investigadas.

A necessidade desta pesquisa casou-se com a percepção de que havia alguns movimentos que já estavam refletindo sobre essa diferenciação e formulando a respeito dentro da Via Campesina. Dentre eles, destacava-se o já mencionado Movimento de Mulheres 
Camponesas, que não só estava de forma clara colocando o enfrentamento à violência contra a mulher como tema de seu I Encontro Nacional, conforme mostraremos a seguir, mas tinha também, dentre as suas militantes, mulheres que estavam em nível popular - e mesmo acadêmico - colocando a si mesmas como problema.

Materializou-se, pois, a oportunidade de, por um lado, conhecer a realidade de outras mulheres, com vida distinta da que eu levava, fortalecendo em mim, desta maneira, uma práxis mais libertária e em luta contra uma postura colonizadora, de classe média, branca e urbana (que acaba dando o tom a alguns debates do feminismo) e, por outro, aprender como as próprias mulheres do campo e organizadas em movimento estavam realizando a tarefa, a fim de poder colaborar com as situações de uma forma menos discrepante quando fosse chamada a participar de atividades.

Aventurar-me a conhecer a outra abriu-me a possibilidade de conhecer a mim mesma em um momento muito específico da vida. Eu engravidei, de forma não planejada, no começo do mestrado, depois do término de um namoro a distância, o que me colocou na posição de "mãe solteira", de modo que passei toda a pesquisa de campo ou grávida ou carregando um bebê pequeno sozinha. E aquelas mulheres que já colocavam em questão a sua condição de cuidar dos filhos, dos homens adultos e da esfera reprodutiva, lutando pela sua independência, divisão de trabalhos e valorização do que realizavam, me atingiram em cheio, pois estava enfrentando na própria pele o peso construído socialmente de ser a principal responsável pelos cuidados de uma criança. O estranhamento, por um lado, e o reconhecimento, de outro, marcariam profundamente as linhas que se seguem.

\section{Trilhando o caminho: o mapa e os óculos usados, ou o método}

Contra uma maré que desenha cada vez mais o estudo do específico, de um particular desconectado do todo, trabalhei uma metodologia que busca a compreensão da complexidade, da historicidade e, portanto, da totalidade dos processos.

A totalidade é uma categoria que perseguirei, com seus riscos e suas vantagens, no decorrer deste trabalho. Pensando nas suas vantagens, imaginando que darei conta do recado em muitos momentos, possibilitando, a quem me lê, uma imersão no mundo das camponesas, a partir de uma narradora externa a ele, compreendendo como esse mundo está articulado (ou 
não) com outras questões na sociedade; em relação às desvantagens, tendo a compreensão de que lidarei com algumas distorções e incompletudes, decorrentes da própria natureza de um trabalho realizado com essa pretensão em sede de mestrado.

Temo, por muitas vezes, não ter fôlego suficiente para esse mergulho, de me perder em superficialidades, no afã de tudo captar, no afã de atender a todas as nuances. Mesmo assim, assumo o risco e ouso porque realmente acredito que poderei contribuir colocando o movimento em meio à complexidade que é a própria relação social.

Da fala deste específico, que é a mulher camponesa e da luta contra a violência que a atinge a partir do também específico Movimento de Mulheres Camponesas, emerge a possibilidade de compreendê-la como parte e integrante de vários outros processos e movimentos que agem a nível individual, local, regional, nacional e internacional.

Um movimento que é construído e também desconstruído, porque está em permanente questionamento e sedimentação, de forma dialética; que tem a necessidade de vislumbre de questões articuladas, como gênero, classe e determinação da sexualidade.

As categorias escolhidas, portanto, seguirão o rumo de busca da compreensão da totalidade, tomando a realidade em seu aspecto materialista histórico e de fundo marxista. É o materialismo, histórico e dialético, que dará o tom a este trabalho, propondo diálogos entre o Direito, a teoria de movimentos sociais e os feminismos.

Por outro lado, reforço que todo o trabalho desenvolvido aqui é realizado a partir de uma visão alheia, de uma pessoa que não vivencia diretamente as situações apontadas e que não trabalhou em meio ao processo para o alcance de soluções. De fato, percebo, de pronto, que o Movimento de Mulheres Camponesas já tinha percepções sobre o enfrentamento à violência contra a mulher no campo e já tinha traçado caminhos pelos quais estava trilhando. Decido, diante dessa constatação, que havia a necessidade de conhecer o que existia.

O método escolhido, pois, destarte toda uma biografia construída de pesquisar em meio à militância, utilizando pesquisas participantes, e mesmo com o atrevimento de realizar trabalhos utilizando a metodologia da pesquisa-ação, foi o da observação participante. Um olhar externo, que não interferia nos processos, mas que se fez atento para perceber as nuances e de ouvir as vozes, situando-as em contextos e confrontando-as ou articulando-as com a teoria.

Atrevo-me em outro ponto. O de relacionar teoria e prática durante a escrita de quase todo o trabalho, quando, tradicionalmente, as análises são separadas: primeiramente, a teoria, e 
depois a prática, a pesquisa empírica. Ao formato escolhido devo inicialmente a devida menção à Lívia Gimenes, pesquisadora e militante feminista, que me ajudou quanto às primeiras inquietações sobre o trabalho, compartilhando a sua experiência na elaboração de uma dissertação de mestrado articulando "O Direito Achado na Rua" e o feminismo, e que me colocou a seguinte questão: por que não apresentar de pronto, já no primeiro capítulo e por todo o trabalho, os resultados da pesquisa? A provocação despertou meu interesse, mas ainda tive medo de não dar conta de falar nem de uma (teoria) nem de outra (prática) de forma satisfatória. Resisti, portanto. Acreditei que teria o trabalho mais organizado se, para cada capítulo, primeiramente, realizasse uma divisão entre teoria e prática do movimento.

Era o caminho aparentemente mais fácil, mas a todo momento me inquietava. Meu coração estava a gritar desde que comecei a escrever sobre a teoria, porque a todo instante lembrava o que, naquela teoria, estava relacionado com o que eu havia visto e ouvido durante os meses da pesquisa de campo em que acompanhei as reuniões da coordenação do movimento e os espaços do I Encontro Nacional de Mulheres Camponesas, seja analisando documentos ou realizando as entrevistas.

A essa ligação também devo uma ressalva especial ao meu orientador, que me provocava a todo momento quando eu falava sobre algum marco teórico ou categoria escolhida com a pergunta que ele gosta de fazer: "sim, mas o que tu quer com isso?", me provocando a justificar todas as minhas escolhas teóricas.

Ora, se eu me propunha a uma análise dialética, por que não intercalar, de pronto, os dados com a teoria, provocando um desenrolar incessante de sínteses, proporcionando, em verdade, não a visão sobre a prática, mas sobre a práxis, como 'teoria praticada e prática teorizada (FREIRE, 2005)?

O encorajamento final, como o foi em outras ocasiões, inclusive para a própria realização desta escrita, veio ainda do orientador, que sugeriu que eu fosse tentando construir essa possibilidade no decorrer do trabalho, mas que isso não fosse uma "camisa de força". $\mathrm{O}$ que quis dizer que, diante da necessidade de se abrir tópicos próprios para análise de dados, que eu o fizesse, estabelecendo as possíveis referências com a teoria que já houvesse escrito.

Assim realizei.

No entanto, o processo de escrita não foi esse perfeito encadeamento. Houve momentos em que, para dar maior fluidez e rapidez, me ative a traduzir o que eu queria das categorias. A reescrita das teorias com as minhas palavras me ajudava a me ressituar, me conectar. No 
momento em que me lembrava de algo sobre a práxis do movimento, eu fazia breves apontamentos e posteriormente desenvolvia em bloco essas interlocuções e confrontações com a teoria. Espero que aos leitores faça tanto sentido como para mim.

Quanto aos métodos e técnicas utilizados, cabe registrar que o meio inicialmente escolhido foi o da entrevista semiestruturada, que realizei no total de quatro, mas depois surgiu a necessidade de trabalho com questionários tendo o roteiro como base. Também foi necessário retorno posterior a campo, com entrevistas semiestruturadas, para sanar algumas dúvidas que apareceram no momento da escrita.

Em alguns casos, consegui realizar as entrevistas pessoalmente, tendo diante de mim o roteiro testado; em outras, utilizei as mesmas perguntas, mas encaminhei as questões para que as entrevistadas escrevessem as respostas. Isso aconteceu porque realizei parte do campo carregando meu filho de poucos meses junto comigo, a fim de garantir o aleitamento materno com exclusividade nos primeiros seis meses, o que foi alcançado, mas com prejuízos para a realização de parte das entrevistas no formato inicialmente programado.

Outro fator dificultou a realização das entrevistas: a falta de um momento reservado exclusivamente para esse fim. $\mathrm{Na}$ verdade, houve o aproveitamento das reuniões da Coordenação Nacional do MMC em Brasîlia para realização das conversas nos intervalos possíveis. Ocorre que a agenda de reuniões era sempre muito extensa e, tanto as mulheres do MMC como eu, estávamos exaustas nos intervalos das atividades ou no fim do dia. Desse modo, realizamos as conversas diante da possibilidade delas e da minha.

Nesse ritmo, consegui realizar de $20 \%$ a $25 \%$ do esperado por reunião que participava, entre, inicialmente, o cansaço com o avançar da gestação e, posteriormente, entre mamadas, choros e cansaço com os cuidados com o bebê e de espera pelos momentos menos desgastantes para realização da conversa; de modo que eu complementei a coleta de dados por meio do envio das perguntas por e-mail, que as integrantes da coordenação respondiam como podiam.

Assim, de um lado, não consegui as informações e os dados que esperava conseguir com as entrevistas nos intervalos de atividade do movimento e com a aplicação dos questionários a distância, com a exceção de duas entrevistas que foram extremamente ricas e que, por si só, deram os caminhos para o confronto com a teoria. Com elas, consegui muitas luzes para a construção deste trabalho. 
Por outro lado, ter observado e gravado parte dos debates realizados na pauta dessas reuniões possibilitou a coleta de muito conteúdo que se correspondia ou mesmo coincidia com as perguntas propostas nos roteiros.

Nesses momentos, a fala das integrantes da coordenação era até mais rica do que quando estavam tentando responder às questões que eu realizava. Em um desses momentos, de forma não programada, iniciou-se um relato sobre o enfrentamento à violência contra as mulheres camponesas estado a estado, momento em que as camponesas relataram suas percepções sobre a violência sofrida pelas mulheres a nível estrutural, articulando-a com a violência sofrida pelo companheiro amoroso nas relações familiares. Momentos extremamente ricos que serão apresentados nas páginas a seguir.

No que se refere à esfera do programado, ainda, pude acompanhar várias atividades públicas do movimento, como mobilizações de rua, participações em audiências públicas em conjunto com a Articulação de Mulheres Brasileiras (AMB) e reuniões com representantes do Congresso Nacional, em novembro de 2012, o próprio I Encontro Nacional de Mulheres Camponesas, em fevereiro de 2013 (quando eu já completava nove meses de gravidez, tendo participado, inclusive, de uma das místicas do encontro, o que me levou a refletir sobre as simbologias utilizadas pelo movimento e sua possibilidade crítica), participação em mesas de seminário, como a realizada no Conexões IV “Feminismo, Campesinato e Luta de Classes", em setembro de 2014.

Houve também a possibilidade de trabalhar com as gravações em vídeo de vários momentos que ocorreram durante o I Encontro Nacional de Mulheres Camponesas, tanto produzidas pelo próprio MMC como pela mídia nacional. Como a temática do encontro foi ' $\mathrm{Na}$ sociedade que a gente quer, basta de violência contra a mulher”, a questão da violência, e a visão do movimento sobre ela, era a todo tempo colocada como tópico nas entrevistas e vídeos. Por outro lado, dentre os objetivos do encontro, também se colocou a discussão sobre o próprio movimento, de modo que a história do MMC era a todo instante posta e refletida pelas participantes. Por fim, a participação da presidenta Dilma no encontro, com o seu staff, foi filmada e disponibilizada, de modo que pudemos analisar o conteúdo do discurso que acaba tendo seu rebatimento sobre como as políticas públicas são pensadas e operadas. 


\section{Dos óculos à escolha do destino: por que essa trilha e essa paisagem}

Cabe-me da mesma forma, invocar quais as motivações acadêmicas que me levaram a compreender este tema e o seu recorte como relevantes para figurarem como objeto de produção do conhecimento.

Em cascata, uma série de questões se articularam de modo a produzir o recorte final alcançado. Pesquisei a temática da violência contra a mulher camponesa, segundo o ponto de vista da coordenação do Movimento de Mulheres Camponesas Brasil (MMC Brasil).

Escolhi, pois, ainda, o tema "violência contra a mulher". Mas por que, se já alcançamos um patamar em que há legislações e políticas públicas específicas de enfrentamento à violência e de fortalecimento das mulheres? Isso não tiraria um tanto da relevância de novamente se escrever sobre o tema? Acredito que não.

Em primeiro lugar, porque a maior causa de morte no Brasil para as mulheres continua sendo ter um relacionamento afetivo e/ou tentar se livrar dele. Todos os dias são cometidos assassinatos de mulheres, feminicídios ${ }^{1}$ se preferirem, cometidos por pessoas em quem a mulher confiava e com quem mantinha (ou havia mantido) relação. O local em que isso mais acontece é o espaço doméstico ${ }^{2}$. Há que se questionar constantemente quais as saídas que podem ser encontradas e fortalecidas para combate a esse quadro.

Justifico também com fundamento na compreensão de que a Lei Maria da Penha e outras legislações que favoreçam a saída do ciclo de violência não são solução, mas instrumentos que se colocam diante de um quadro historicamente construído e do qual tem se observado que não se sairá de forma generalizada com tanta facilidade. Faz-se importante que se verifique até que ponto tem sido construída a aplicabilidade da lei e de demais instrumentos, como as políticas

\footnotetext{
${ }^{1}$ No Brasil, o feminicídio foi inserido no Código Penal Brasileiro pela Lei n. 13.104/2015. Como a própria lei coloca, considera-se feminicídio o as sas sinato de uma pessoa "por razões da condição de sexo feminino" (art. 121, $\S 2^{\circ}$, VI do Código Penal Brasileiro). O código diz ainda: "Considera-se que há razões de condição de sexo feminino quando o crime envolve: I - violência doméstica e familiar; II - menosprezo ou discriminação à condição de mulher." (Art. 121, $\S 2^{\circ}$, VI, $\S 20-A$, I e II do Código Penal Brasileiro). Disponível em: <http://www.planalto.gov.br/ccivil_03/Decreto-Lei/De12848.htm>. Acesso em: 11 mar. 2015.

2 De acordo com matéria publicada em 8 de agosto de 2011, do jornal Folha de S. Paulo: "O ambiente doméstico é cerca de três vezes mais perigoso para as mulheres do que para os homens. Dentre as mulheres assassinadas no país, 28,4\% morreram em casa. O número é quase três vezes maior do que a taxa entre os homens, de $9,7 \%$ ". Dis ponível em: <http://m.folha.uol.com.br/cotidiano/956164-28-das-mulheres-as sas sinadas-no-pais-morrem-e mcasa.html>. Acesso em: 10 dez. 2014.
} 
públicas têm sido pensadas e realizadas e como a sociedade tem se movimentado nos espaços institucionais e não institucionais para construção de caminhos.

Identifico, ainda, conforme coloquei no tópico anterior, que havia desafios outros, questões específicas que deveriam ser verificadas quando se tratava de violência cometida contra as mulheres do campo.

Em pesquisa bibliográfica preliminar, tomando como base pesquisas e publicações realizadas por entidades feministas como o $\mathrm{SOSCO} \mathrm{Corpo}^{3}$, outros trabalhos acadêmicos ${ }^{4}$ e mesmo documentos do governo ${ }^{5}$, a fala de que havia poucos dados repetia-se; mas todos admitiam que era flagrante a necessidade de uma visão diferente sobre o enfrentamento à violência contra a mulher, a depender se ela estava no campo ou na cidade. Em outras palavras, o contexto socioeconômico e cultural dessas mulheres deveria ser levado em consideração e soluções diversas precisavam ser encontradas.

Neste trabalho, no entanto, não me deterei de forma convencional a trabalhar a questão da violência contra a mulher a partir da Lei Maria da Penha e das políticas públicas voltadas às questões entre parceiros íntimos. Não. Esse será um tema transversal e tocado diretamente apenas em alguns pontos do trabalho. A minha percepção, no decorrer do campo, foi a de que o ponto de maior contribuição do Movimento de Mulheres Camponesas era o de exatamente perceber a violência contra a mulher praticada por parceiro íntimo como parte de um contexto maior. A ideia de violência contra a mulher é mais ampla. Esse será o meu mote.

Por fim, por que a escolha de um movimento social como fala autorizada para dizer sobre a luta pelo direito a uma vida sem violência e por que o trabalho de campo, ainda, a partir da coordenação desse movimento e não de sua base?

Em primeiro ponto, porque acredito que os movimentos sociais são peças diferenciadas na criação, transformação e significação do Direito. Afirmo tal ideia tendo como fundamento

\footnotetext{
${ }^{3}$ SILVA, Carmen (Org.). Experiências em Pedagogia Feminista. Recife: SOS Corpo - Instituto Feminista para a Democracia, 2010a.

${ }^{4}$ Como o que resultou no livro "Gênero e geração em contextos rurais", organizado por Parry Scott, Rosineide Cordeiro e Marilda Menezes, publicado em 2010. Disponível em: $<$ https://www.ufpe.br/fagesufpe/images/documentos/Livros_Fages/genero\%20e\%20gera_o\%20em\%20contextos \%20rurais.pdf>. Acesso em: 20 mar. 2015.

5 “(...) um dos desafios para a implementação de políticas de enfrentamento à violência contra as mulheres do campo e da floresta diz respeito à escassezde dados específicos sobre o fenômeno", segundo as Diretrizes e Ações Nacionais de Enfrentamento à Violência contra as Mulheres do Campo e da Floresta, de 2011 (Coleção Enfrentamento à Violência Contra as Mulheres, SPM, p. 21). Disponível em: <http://www.spm.gov.br/sobre/publicacoes/publicacoes/2011/campo-e-floresta〉. Acesso em: 18 mar. 2015.
} 
que o Direito é construído a partir de uma dialética social e de disputas entre classes e grupos da sociedade, conforme veremos.

Em segundo ponto, porque já faz um tempo dentro do Estado brasileiro que os movimentos sociais e a parte da população que se reúne em Organizações da Sociedade Civil, as agora chamadas OSCs, são chamados a participar de espaços colegiados com o executivo, em que as políticas públicas são pensadas, ou mesmo de audiências públicas, nas quais leis são formuladas e revistas. Não é à toa que se construiu há bem pouco tempo uma normativa específica para traçar o Marco Regulatório das Organizações da Sociedade Civil ${ }^{6}$ e todo o processo mesmo foi realizado em debate com esses atores.

O Movimento de Mulheres Camponesas foi escolhido, de forma mais específica, porque, a uma, integra um fórum no âmbito da Secretaria de Políticas para as Mulheres da Presidência da República (SPM/PR) que discute a questão da violência contra a mulher do campo e das florestas 7 ; a duas, tem nítido reconhecimento entre outros movimentos de luta pela terra e feministas; a três, porque consegue articular, em conjunto com outras organizações como a Articulação de Mulheres Brasileiras (AMB), audiências públicas para debate nas Casas Legislativas Federais; e, finalmente, a quatro, porque possui um escritório em Brasîlia (DF), bem como realiza reuniões da coordenação na capital federal, possibilitando que a atividade de campo se desenvolvesse de forma muito rica.

Quanto à escolha sobre o trabalho com as lideranças do movimento, isso se deu tendo em vista que se queria conhecer o que o movimento pensava acerca das políticas públicas realizadas pelo governo federal a partir da SPM/PR, e que é a coordenação do movimento quem assume a tarefa de representar o MMC em espaços institucionais, que amadurece e elabora as

\footnotetext{
6 Lei n. 13.019/2014. Disponível em: <http://www.planalto.gov.br/ccivil_03/_Ato20112014/2014/Lei/L13019.htm>. Acesso em: 18 mar. 2015.

${ }^{7}$ Fórum Nacional Permanente de Enfrentamento à Violência contra as Mulheres do Campo e da Floresta, criado pela Portaria n. 42, de 23 de agosto de 2007 da SPM/PR. O fórum é integrado por dez órgãos governamentais (Secretaria Especial de Políticas para as Mulheres - SPM e de Políticas da Promoção da Igualdade Racial SEPPIR; Secretaria Especial de Direitos Humanos - SEDH, Secretaria Geral da Presidência da República SG/PR; Ministérios do Desenvolvimento Agrário - MDA, da Agricultura, Pecuária e Abastecimento - MAPA, da Saúde - MS, do Desenvolvimento Social e Combate à Fome - MDS, da Justiça - MJ, do Meio Ambiente - MMA) e oito movimentos sociais (Movimento de Mulheres Trabalhadoras Rurais do Nordeste - MMTR/NE, Movimento de Mulheres Quebradeiras de Coco - MIQCB, Movimento de Mulheres Camponesas - MMC, Federação dos Trabalhadores na Agricultura Familiar - FETRAF, Confederação Nacional dos Trabalhadores na Agricultura CONTAG, Conselho Nacional dos Seringueiros - CNS, Movimento Articulado de Mulheres da Amazônia MAMA e Marcha Mundial das Mulheres - MMM). Dados retirados das Diretrizes e Ações Nacionais de Enfrentamento à Violência contra as Mulheres do Campo e da Floresta (Coleção Enfrentamento à Violência Contra as Mulheres, SPM, p. 21). Disponível em: <http://www.spm.gov.br/sobre/publicacoes/publicacoes/2011/campo-efloresta>. Acesso em: 18 mar. 2015.
} 
propostas de pauta a serem apresentadas para a base. As integrantes da coordenação foram as mediadoras com quem eu pude conversar para a obtenção das informações desejadas.

Por fim, ainda, cabe mencionar que a direção do movimento mostrou-se e mostra-se muito aberta ao desenvolvimento de pesquisas que possam favorecer a sua ação-reflexão e práxis no enfrentamento às violências sofridas pelas mulheres camponesas. Esse ponto foi um facilitador no processo tendo em vista que pude participar de reuniões fechadas da coordenação do movimento.

\section{Lyra, meu amigo: diálogos com Roberto Lyra Filho sobre as lutas do Movimento de Mulheres Camponesas}

Este trabalho apresenta-se, finalmente, dentre uma de suas tarefas, com a finalidade de dar continuidade à integração da obra de Roberto Lyra Filho. Como já diria Frei Betto, "a cabeça pensa onde os pés pisam", ou o próprio Marx: "Não é a consciência que determina a vida, mas a vida que determina a consciência" (MARX; ENGELS, 2007, p. 94). Lyra Filho não é diferente. Embora a sua grande possibilidade de enxergar as transformações que aconteciam e conseguir pensar e refletir sobre elas, compreendemos que Lyra Filho escreveu em um tempo e seu pensamento é reflexo e espelho de um contexto específico.

Em meio a várias outras questões que precisam ser repensadas a partir do nosso contexto, chama a minha atenção especificamente a das mulheres enquanto sujeito oprimido e, portanto, potencial agente transformador de sua própria realidade. Não que Lyra não tenha mencionado a questão das mulheres, como veremos mais para frente, mas acredito que, segundo um paradigma feminista, essa é uma questão a ser integrada ao "Direito Achado na Rua", ao humanismo dialético e à dialética social do direito.

Lyra Filho se sentia não só autorizado, mas conclamado a "superar" a obra marxista. Da mesma forma, sinto-me portanto, não somente autorizada, mas quase que convocada a "profanar" a obra do estimado professor Lyra Filho e dar continuidade à caminhada dialética que ele se propôs a fazer sobre a obra marxista e a possibilidade de construção de uma dialética social do Direito a partir do que chamou de humanismo dialético.

Não inovo de todo nesse ponto. Aqui cabe mencionar o trabalho monográfico de Carolina Tokarski intitulado "A extensão nos cursos de direito à luz do humanismo dialético: a 
experiência do projeto Promotoras Legais Populares" e a dissertação de mestrado de Lívia Gimenes denominada "A luta pela liberdade em casa e na rua: a construção do Direito das Mulheres a partir do projeto Promotoras Legais Populares do Distrito Federal".

Ambas tratam a questão da integração das questões das mulheres à teoria do humanis mo dialético, a partir da noção de direitos humanos desenvolvida por Lyra Filho. É nesse ponto que o autor mais se detém sobre a questão dos grupos sociais oprimidos (dentre os quais, as mulheres) para além da categoria "classe" marxista.

A visão que Lyra Filho tem acerca da construção e significação do Direito pelas classes e grupos sociais e a sua dialética do Direito, traçada no livretinho "O que é Direito"8, foi de grande valia e me serviu de roteiro para caracterização e posicionamento do Movimento de Mulheres Camponesas em meio a outras lutas sociais dos povos do campo.

Por outro lado, a própria análise do conteúdo do discurso das lideranças do Movime nto de Mulheres Camponesas, bem como os vários documentos produzidos por elas, mostrava que havia um ponto a ser criticado no esquema proposto por Lyra Filho e as classes e os grupos sociais precisam ser observados sob um outro ângulo que pude oferecer de acordo com a leitura de algumas feministas. A isso me dedicarei.

Nas próximas páginas, trabalharei, portanto, em três capítulos. No primeiro capítulo, tentei estabelecer um diálogo entre teorias feministas de duas matizes dentro do feminismo, o pós-estruturalismo e o materialismo, para discorrer acerca de uma ideia sobre o feminismo camponês e a "nova mulher" que o Movimento de Mulheres Camponesas proclama. Sigo com um segundo capítulo, sobre teorias que articulam dentro do feminismo as categorias de sexo e classe social e tento situar o debate de violência contra a mulher a partir dessa articulação de categorias, frente às construções do Movimento de Mulheres Camponesas sobre o tema. Por fim, no último capítulo, a partir dessa concepção de violência articulando sexo e classe social, me dedicarei, usando o desenho da dialética social do Direito, a discorrer sobre como tem sido a caminhada dos movimentos de mulheres para a construção do direito a uma vida sem violência.

\footnotetext{
${ }^{8}$ LYRA FILHO, Roberto. O que é direito. 10. ed. São Paulo: Brasiliense, 2005.
} 


\section{CAPÍTULO 1: FEMINISMO CAMPONÊS E AS DINÂMICAS DA IDENTIDADE NA COMPREENSÃO DA VIOLÊNCIA CONTRA A MULHER}

Conforme já expomos, trazemos como centro da nossa discussão a violência sofrida pelas mulheres camponesas, a partir da visão de um movimento social de mulheres, que se autoproclama feminista, situado em um local específico: o campo. Mulheres que afirmam articular-se contra o patriarcado e o capitalismo para a produção de alimentos saudáveis e a libertação e valorização da mulher camponesa.

Lidaremos, então, com uma série de conceitos e categorias que merecem reflexão, a fim de possibilitar a análise do conteúdo do discurso sobre a violência contra a mulher e as formas de pauta desta questão nos espaços institucionais e não institucionais; espaços nos quais o movimento atua pleiteando, criticando ou reivindicando o direito posto (leis e outros atos normativos) e as políticas públicas existentes.

É a análise dessas categorias face às compreensões do Movimento de Mulheres Camponesas que situarão o debate e possibilitarão a estruturação do nosso próprio discurso.

O aporte teórico nos servirá para analisar os textos produzidos pelo próprio Movimento de Mulheres Camponesas, as entrevistas e o material levantado no período da observação participante. O conteúdo selecionado para análise versa sobre o que o movimento entende por sua própria identidade e como compreende a violência contra o grupo específico que representa.

\subsection{Mulher, mulheres: quem é ela, quem são elas?}

Temos dois pontos de partida no presente trabalho: um deles é a constatação de que ainda há violência sexista e misógina ${ }^{9}$, ou seja, as mulheres sofrem violência pelo simples fato de serem mulheres. O outro ponto é que esta violência, no entanto, não é sentida da mesma

\footnotetext{
${ }^{9} \mathrm{~A}$ violência sexista pode ser exclusivamente baseada no machismo, ou seja, agir com violência velada contra as mulheres para que elas se submetam aos homens e à cultura machista. Mas há verdadeiros atos que destacam uma violência mais direta por motivo de ódio com o que seja considerado como relativo às mulheres, daí a diferenciação dos termos. De forma bastante didática, a blogueira brasileira feminista Lola Aronovich discorre sobre os termos quando escreveu sobre um espancamento que a cantora norte-americana Rihanna sofreu de seu companheiro, o também cantor norte-americano Chris Brow, no post intitulado "Misoginia, machismo. E Rihanna espancada por Chris Brow", de 12 de fevereiro de 2009. Disponível em: <http://escrevalolaescreva.blogspot.com.br/2009/02/misoginia-machis mo-e-rihanna-espancada.html〉. Data de acesso: 30 jun. 2014.
} 
forma por elas. Deste modo, entendemos como necessário discorrer sobre algumas teorias que colocam a categoria "mulher", como ser genérico, em questão.

Antes, portanto, de nos debruçarmos sobre a problemática da violência em si, a especificidade vivenciada pelas camponesas e a percepção de um movimento que se autoproclama camponês e feminista, tema que será objeto ainda deste capítulo, cabe-nos situar o presente trabalho com o apoio na teoria feminista sobre o que é "mulher".

Como breve impulso inicial para este tópico, relembramos, com apoio no resgate empreendido por Santos (2002), Young (1987) e Lowy (1991), que o conhecimento científico, enquanto forma de desvendar a realidade social e a construção de categorias universais, ganha ares no século XVIII, a partir do Iluminismo, com a ciência social positivista.

Levantou-se a ideia de que, de forma assemelhada à natureza, compreendida naquele momento como oposto ao humano, a sociedade também funcionava a partir de leis gerais, mas, por um motivo ou outro (aos quais não nos deteremos, limitando-nos a expor que são de raiz humana), esse funcionamento, que nem sempre era harmônico, poderia (e deveria) ser corrigido, a partir de padrões identificados como normais, com a correção, segregação ou extermínio do sujeito desviante a partir de sua submissão, clausura ou até morte ${ }^{10}$.

O sistema de identificação de leis gerais, como princípio que deveria ser perseguido para a formulação de conhecimento científico social, sustentava-se na evidenciação de pares dicotômicos: um dos pares identificava o que era geral, normal, e o outro lado demarcava o acaso, o anormal, um Outro que, fugindo daquele padrão, precisava ser normalizado (YOUNG, 1987).

Falando sobre a lógica que governou o pensamento moderno, a lógica da identidade, Young (1987) retoma que:

\footnotetext{
${ }^{10}$ Aqui, lembramos o início da modernidade, que conviveu com o extermínio físico dos povos dos continentes colonizados que não se curvaram à morte da sua cultura (TODOROV, Tzvetan. A conquista da América: a ques tão do outro. São Paulo: Martins Fontes, 1982; DUSSEL, Enrique. 1492: o encobrimento do outro. A origem do mito da modernidade. Petrópolis: Editora Vozes, 1993), ao extermínio em massa de mulheres queimadas como bruxas porque fugiam ao nascente padrão burguês-católico na Santa Inquisição, entre outros, bem como o que foi aprimorado durante a modernidade segundo a pers pectiva de controle-correção com a instituição dos hospícios e prisões que segregavamos mais diversos grupos "problemáticos". Fontes: Michel Foucault parlui-même (2003), filme dirigido por Philippe Calderón, dis ponível em: 〈http://www.youtube.com/watch?v=Xkn31sjh4To〉, acesso em: 27 nov. 2014; FOUCAULT, Michel. Vigiar e punir: nascimento da prisão. Tradução de Raquel Ramalhete. Petrópolis: Vozes, 1987; MENDES, Soraia da Rosa. (Re)pensando a criminologia: reflexões sobre um novo paradigma desde a epistemologia feminista. 2012. 284 f. Tese (Doutorado em Direito) - Universidade de Brasília, Brasília, 2012. Disponível em: <http://repositorio.unb.br/bitstream/10482/11867/1/2012_SoraiadaRosaMendes.pdf>. Acesso em: 27 nov. 2014.
} 
A lógica da identidade consiste numa incansável insistência em pensar as coisas juntas, numa unidade, para formular uma representação do todo, uma totalidade. Esse desejo por sua vez é pelo menos do tempo de Parmênides, e a lógica da identidade começa com a antiga noção filosófica dos universais. Mediante a noção de uma essência, o pensamento reúne particulares concretos numa unidade. Na medida, porém, em que a diferença qualitativa define a essência, o simples programa de identificar pensamento permanece incompleto. Os particulares concretos são unificados sob a forma universal, mas as formas por sua vez não podem ser reduzidas a unidade.

O ego cartesiano que inaugura a filosofia moderna concretiza o projeto totalizante.

$(\ldots)$

A lógica da identidade vai além desse empenho por ordenar e explicar os particulares da experiência. Ela constrói sistemas completos que procuram mergulhar a alteridade das coisas na unidade do pensamento. O problema com a lógica da identidade é que, através dela, o pensamento procura ter tudo sob controle, eliminar toda incerteza e imprevisibilidade, idealizar o fato corporal da imersão sensorial num mundo que ultrapassa o sujeito, eliminar a alteridade. (...)

(...)

De um modo típico a lógica da identidade gera dicotomia em vez de unidade. $\mathrm{O}$ ato de reunir particularidades sob uma categoria universal cria uma distinção entre interior e exterior. Dado que cada entidade ou situação particular têm tanto semelhanças como diferenças em relação a outras entidades e situações, e tendo em vista que não são completamente idênticas nem absolutamente outras, a insistência em unificá-las numa categoria ou princípio, inevitavelmente significa deixar de fora algumas das propriedades das entidades ou situações. E já que o movimento totalizador sempre deixa um remanescente, o projeto de reunir particulares à unidade deve falhar. Não satisfeita, pois, em admitir derrota diante da diferença, a lógica da identidade impele a diferença a oposições normativas dicotômicas: essência-acidente, bom-mau, normal-desviante. Todavia, as dicotomias não são simétricas, mas formam uma hierarquia; o primeiro terno designa a unidade positiva no interior, o segundo termo menos valorizado designa a sobra exterior (p. 7072).

Em verdade, o processo não era de descoberta de leis gerais, mas de generalização de um ponto de vista e de uma forma de ser e estar no mundo que atendia a interesses de classes e grupos sociais na configuração de poder que coordenava a ordem daquela época (SANTOS, 2002). Um conhecimento, portanto, interessado, apesar de que uma das pretensões da ciência, inclusive a social, era a descoberta de um conhecimento verdadeiro e válido porque destituído de interesse, neutro (SANTOS, 2002; LOWY, 1991).

Sendo mais precisa e clara: temos o homem, de cor branca, de classe proprietária, europeu, heterossexual e adulto como padrão de normalidade e a mulher, as pessoas de cor 
distinta da branca, as classes trabalhadoras, os povos não europeus, as pessoas não heterossexuais e as crianças e velhos como o acidente, o incompleto. A esses grupos era atribuída uma racionalidade inexistente ou pouco desenvolvida e que, em virtude disso, precisavam ser tutelados pelo primeiro grupo.

Não foi à toa que o padrão de humanidade fosse nomeado por "homem" como ser geral, um termo que até hoje é entendido como gênero humano, porque o homem mesmo era o referencial de normalidade, que indicava o ser racional, e a mulher o Outro, como nos apontou Simone de Beauvoir:

Ninguém nasce mulher: torna-se mulher. Nenhum destino biológico, psíquico, econômico define a forma que a fêmea humana assume no seio da sociedade; é o conjunto da civilização que elabora esse produto intermediário entre o macho e o castrado que qualificam de feminino. Somente a mediação de outrem pode constituir um indivíduo como um Outro (1970b, p. 9).

(...) A humanidade é masculina e o homem define a mulher não em si mas relativamente a ele; ela não é considerada um ser autônomo. "A mulher, o ser relativo...", diz Michelet. E é por isso que Benda afirma em Rapport d'Uriel: "O corpo do homem tem um sentido em si, abstração feita do da mulher, ao passo que este parece destituído de significação se não se evoca o macho... O homem é pensável sem a mulher. Ela não, sem o homem". Ela não é senão o que o homem decide que seja; daí dizer-se o "sexo" para dizer que ela se apresenta diante do macho como um ser sexuado: para ele, a fêmea é sexo, logo ela o é absolutamente. A mulher determina-se e diferencia-se em relação ao homem e não este em relação a ela; a fêmea é o inessencial perante o essencial. O homem é o Sujeito, o Absoluto; ela é o Outro (1970a, p. 10). ${ }^{11}$

\footnotetext{
${ }^{11}$ Ainda Simone de Beauvoir sobre a questão da mulher como o Outro (em nota de rodapé, páginas 10 e 11$)$ : "Essa ideia foi expressa em sua forma mais explícita por E. Levinas em seu ensaio sobre Le Temps et l'Autre. Assim se exprime êle: 'Não haveria uma situação em que a alteridade definiria um ser de maneira positiva, como essência? Qual é a alteridade que não entra pura e simplesmente na oposição das duas espécies do mesmo gênero? Penso que o contrário absolutamente contrário, cuja contrariedade não é em nada afetada pela relação do que se pode estabelecer entre si e seu correlativo, a contrariedade que permite ao termo permanecer absolutamente outro, é o feminino. O sexo não é uma diferença específica qualquer... A diferença dos sexos não é tampouco uma contradição... Não é também a dualidade de dois termos complementares, porque esses dois termos complementares supõem um todo preexistente... A alteridade realiza-se no feminino. Termo do mesmo quilate mas de sentido opos to à consciência'. Suponho que Levinas não esquece que a mulher é igualmente consciência para si. Mas é impressionante que adote deliberadamente ponto de vista de homem sem assinalar a reciprocidade do sujeito e do objeto. Quando escreve que a mulher é mistério, subentende que é mistério para o homem. De modo que essa descrição que se apresenta comintenção objetiva é, na realidade, uma afirmação do privilégio masculino".
} 
Marx, já no século $\mathrm{XIX}^{12}$, acusa que esse conhecimento produzido até o momento não era neutro, mas guiado pelos interesses de classe, de forma que esse ser geral, em verdade, se tratava do homem burguês retratado:

Com sua fé capaz de mover montanhas, nosso Jacques le bonhomme [Max Stirner $]^{13}$ aceita como base real, profana, do mundo burguês a forma distorcida pela qual a ideologia carola e hipócrita dos burgueses expressa seus interesses particulares como interesses universais (2007, p. 180).

A denúncia do caráter classístico daquela ciência e conhecimento foram defendidos e aprofundados pelos marxistas, como nos aponta Michel Lowy (1991), com vistas à descoberta de um "conhecimento verdadeiro" e emancipador, mesmo sendo este interessado.

Os marxistas abriram caminho para que questionamentos, para além da dominação de uma classe social sobre a outra na construção de conhecimento, fossem realizados.

Mas se todo conhecimento é parcial e interessado, é possível alcançar alguma forma de conhecimento verdadeiro sobre uma questão, podendo estendê-la a outras questões assemelhadas com base em processos de generalização?

No que diz respeito às classes sociais, a solução identificada, segundo análise de Lowy (1991), a qual nos filiamos inclusive para questões atinentes a grupos da sociedade em relação a gênero e raça, é que boa parte do conhecimento hegemônico produzido, bem como suas instituições de controle, tem limitações no que diz respeito à busca da verdade, porque tem compromissos com as classes e grupos que detêm o poder na sociedade e que produzem esse mesmo conhecimento que as beneficia.

Dessa forma, seria necessário que as classes e os grupos sociais oprimidos, e intelectuais aos quais se aproximam, produzissem um conhecimento que, ao passo em que conduzisse a uma visão da totalidade, a partir da situação das particularidades dentro dessa totalidade, se traduzisse em emancipação (LOWY, 1991).

Em outras palavras, não haveria, portanto, um ser universal, mas diversos grupos na sociedade, com interesses diversos, ligados entre si por complexas relações de poder que

\footnotetext{
12 O livro “A Ideologia Alemã” foi escrito entre 1845-1846, embora tenha sido publicado somente em 1933.

13 Filósofo alemão criticado por Marx e Engels na obra “A Ideologia Alemã”.
} 
submeteriam um grupo ao outro. Produzir conhecimento sobre esses grupos pode significar (ou não) aclarar essas relações de poder, a partir do interesse do próprio produtor do conhecime nto em questionar ou manter a configuração da submissão de um grupo ao outro.

Em uma linha de pensamento que se assemelha ao caminho trilhado acima, parte do feminismo que tinha se organizado dentro das universidades, o chamado "feminismo acadêmico"14 também acusou que havia uma questão epistemológica a ser resolvida na produção do conhecimento: o falseio que colocava as mulheres como o Outro do homem ${ }^{15}$.

Mas, como ocorreria em geral com a teoria do conhecimento, parte das feministas foram além e questionaram acerca de um segundo passo que deveria ser dado: como produzir conhecimento sem gerar novos falseios com base em generalizações que obscurecessem que estas eram fundadas em particularidades que, hegemônicas, se universalizavam?

De forma mais clara, houve uma acusação de que o feminismo de uma chamada primeira onda $^{16}$, sufragista e liberal, tinha problemas.

Representações do feminismo marxista, do feminismo negro e das lésbicas, estudiosas pós-estruturalistas, pós-modernas, dentre outras, contribuíram bastante com a crítica aos generalismos ao denunciar que a pauta e os estudos feministas estavam sendo hegemonizados por mulheres brancas, europeias ou estadunidenses, com condição econômica e heterossexua is, com as suas necessidades próprias.

O que estava sendo dito sobre o que as mulheres precisavam, quais as mudanças eram pretendidas e quais suas causas, tinham na mulher burguesa o padrão de análise, como modelo do que era ser "mulher", o que ainda hoje é sustentado em alguns estudos:

\footnotetext{
${ }^{14}$ Alguns artigos trazem um pouco da história do feminismo acadêmico e do movimento feminista no Brasil, com um balanço crítico interessante. A título de exemplo trazemos: 1: COSTA, Ana Alice Alcântara; SARDENBERG, Cecília Maria Bacellar. Teoria e práxis feministas na academia: os núcleos de estudos sobre a mulher nas universidades brasileiras. Estudos feministas, 1994; e 2: GONÇALVES, Renata. Sem pão e sem rosas: do feminismo marxista impulsionado pelo Maio de 1968 ao academicismo de gênero. Lutas Sociais, n. 21/22, p. 98110, 2009.

15 Passo iniciado por Simone de Beauvoir, segundo MARIANO (2005). Ver: MARIANO, Silvana Aparecida. O sujeito do feminismo e o pós-estruturalismo. Rev. Estud. Fem., Florianópolis, v. 13, n. 3, dez. 2005. Dis ponível em: $<$ http://www.scielo.br/scielo.php?script=sci_arttext\&pid=S0104-026X2005000300002\&lng=en\&nrm=is $>_{0}>$. Acesso em: 6 set. 2014.

$16 \mathrm{O}$ feminismo da primeira onda é voltado a extensão de direitos civis e políticos, como o direito ao voto, de grande viés liberal e com pautas relativas às mulheres brancas; o feminismo de segunda onda avança sob a discussão da desigualdade e politiza as questões privadas; e já o chamado feminismo de terceira onda vem a realizar uma crítica sobre a monopolização da pauta e dos discursos pelas mulheres brancas e de classe média. ABREU, Zina. Luta das mulheres pelo direito de voto: movimentos sufragistas na Grã-Bretanha e nos Estados Unidos. 2002. Disponível em: 〈http://repositorio.uac.pt/handle/10400.3/380>. Acesso em: 10 dez. 2014.
} 
Apesar das promissoras teorizações marxistas dos anos de 1980, poucos estudos dedicaram-se, em termos de relações de gênero, as práticas de mulheres das classes populares, enquanto, metodologicamente, a "família" permaneceu (e ainda permanece) associada àquelas das classes médias e altas, sendo evidente que as configurações familiares não são da mesma ordem para uma mulher da burguesia e para uma mulher de classe popular (KERGOAT, 2010).

Um feminismo "desde el sur", poscolonial" ${ }^{17}$ (ou descolonial como preferem alguns) ${ }^{18}$ também lançou suas críticas acusando a colonialidade presente em um conhecimento europeu sobre as mulheres dos povos colonizados que não traduziam as especificidades vivenciadas no "sul".

Discussões acerca de um padrão heteronormativo também deram "pano pra manga" aos debates sobre o que era ser mulher.

Identificando que, para além das questões colocadas acima, era preciso ir mais a fundo e questionar padrões essencialistas que não somente oprimiam as mulheres, como outros grupos que se compreendiam e vivenciavam sua sexualidade fora dos padrões construídos a partir de um discurso biologicista sobre os corpos.

O que é ser mulher?

\footnotetext{
17 “Adjetivo de poscoloniales se refiere a una aspiración descolonizadora del conocimiento producido desde el Sur, más que a los procesos de descolonización política que se dieron en Africa y Asia, de donde son originarios algunos de los principales representantes de esta corriente". Ver: NAVAZ, Liliana Suárez; CASTILLO, Rosalva Aída Hernández (Eds.). Descolonizando el Feminismo: Teorías y Prácticas desde los Márgenes. Apresentação, 2008. Disponível em: <http://colegiodesociologosperu.org/nw/biblioteca/des colonizando.pdf〉. Acesso: 10 jan. 2015

18 Os conceitos "descolonial" e "poscolonial" ora são usados pela teoria como sinônimos, evidenciando um trabalho de pensar o mundo a partir do "Sul". Ver: NAVAZ, Liliana Suárez; CASTILLO, Rosalva Aída Hernández (Eds.). Descolonizando el Feminismo: Teorías y Prácticas desde los Márgenes. 2008. Disponível em: $<\mathrm{http}$ ://colegiodesociologosperu.org/nw/biblioteca/descolonizando.pdf>. Acesso: 10 dez. 2014. Ora os conceitos são tomados de forma diversa, sendo que o termo "descolonial" aparece como crítica ao termo "poscolonial", afirmando que o mundo ainda é colonizado econômica e culturalmente, apesar de, em tese, ter sido "descolonizado" politicamente: "El fin de la guerra fría terminó con el colonialismo de la modernidad, pero dio inicio al proceso de la colonialidad global. De este modo, preferimos hablar del 'sistema-mundo europeo/euronorteamericano capitalista/patriarcal moderno/colonial' (Grosfoguel, 2005) y no sólo del 'sistema-mundo capitalista' porque con ello se cuestiona abiertamente el mito de la descolonialización y la tesis de que la posmodernidad nos conduce a un mundo ya desvinculado de la colonialidad. Desde el enfoque que aquí llamamos 'descolonial', el capitalismo global contemporáneo resignifica, en un formato posmoderno, las exclusiones provocadas por las jerarquías epistémicas, espirituales, raciales/étnicas y de género/sexualidad desplegadas por la modernidad. De este modo, las estructuras de larga duración formadas durante los siglos XVI y XVII continúan jugando un rol importante en el presente" (p. 13-14). In: CASTRO-GÓMEZ, Santiago; GROSFOGUEL, Ramón (Eds.). El giro descolonial: reflexiones para una diversidad epistémica más allá del capitalismo global. Siglo del Hombre Editores, 2007. Disponível em:
} <http://www.unsa.edu.ar/his tocat/hamoderna/grosfoguelcastrogomez.pdf>. Acesso em: 10 dez. 2014. 
Ser mãe, esposa, carinhosa, dedicada, heroína, puta, santa, ter vagina e seios? E as pessoas que não podem ser mães embora tenham útero? São mulheres? E as pessoas que tiveram que retirar os seios e útero por razão de doença? Deixam de ser mulheres? E as pessoas que nascem com dois aparelhos genitais desenvolvidos? São homens? Mulheres? E as pessoas que embora tenham nascido com úteros e sejam férteis, não desejem ter filhos ou, tendo-os, não consigam estabelecer com eles relações de afeto e convívio? São mulheres? E as pessoas que nascem com útero e vagina, mas não se identificam com aquele corpo, são mulheres? $\mathrm{E}$ as pessoas que nascem com pênis e não se identificam com aquele corpo, são homens ou mulheres?

E... E... E... os exemplos são vários. O que é ser mulher, afinal? Propor uma articulação com base nessa identidade sempre vai se remeter a essencialismos?

\subsection{Feminismo camponês e a construção de uma "nova mulher"}

Um dos grandes debates do feminismo e estudos de "gênero" versa sobre essencialismos. Existe uma essência feminina? A defesa dessa essência é necessária para a construção da identidade de um movimento feminista?

Dentre a bibliografia pesquisada, um texto produzido acerca do Movimento de Mulheres Camponesas $^{19}$ nos chamou bastante atenção face à categorização do Movimento como possivelmente essencialista por utilizar simbologias que colocariam mulher e natureza como semelhantes, defendendo uma essência feminina e utilizando em sua mística os papéis que foram conferidos às mulheres no campo, em especial, as sementes estabelecendo analogias de guarda das sementes "crioulas" e de guarda das "sementes" humanas.

(...) a concepção religiosa da natureza foi tão fecunda para os movimentos sociais que buscam não só igualdade, mas também equidade para mulheres e homens, ricos e pobres, humanidade e natureza. Porque a natureza, além de divina, é normativa, contendo, embutida na forma de entendê-la, tanto a igualdade entre todas as criações de Deus quanto seu direito de existir e, portanto, de serem respeitadas, amadas e protegidas. Como consequência, essa visão traz a norma de que nós, humanos, temos obrigação de vermos a

\footnotetext{
${ }^{19}$ PAULILO, Maria Ignez S. Intelectuais e militantes e as possibilidades de diálogo. Revista Estudos Feministas, Florianópolis, 16(3), set./dez. 2010, p. 927-940
} 
equidade como 'um direito natural', enquanto derivado da 'natureza' que é divina, uma obra de Deus.

Somente uma sociedade perfeita e, portanto, utópica poderia contemplar a tudo e a todos de maneira a que nada de essencial thes faltasse, seja material, como alimentos, roupas e moradia, seja imaterial, como respeito, espiritualidade e solidariedade. Vê-se a confirmação dessa utopia nas palavras de Allie van der Schaaf que, estudando a busca por direitos sociais e igualdade de gênero no Movimento de Mulheres Agricultoras do Rio Grande do Sul, diz:

O movimento anseia por uma sociedade utópica de "leite e mel", inspirada na Teologia da Libertação, e combina isso com elementos do feminismo teológico. [...] Para recuperar a sociedade de 'leite e mel', seria necessário lutar contra o capitalismo/neoliberalismo [...] reintroduzindo os valores essenciais na vida humana, tais como a dignidade, a igualdade, a solidariedade, a justiça e o prazer, através de uma vivência religiosa espiritual. As mulheres trabalhadoras rurais teriam um papel primordial nessa recuperação da "vida", sendo as parceiras da fertilidade, tanto dos seres humanos quanto da terra (Schaaf, 2001, p. 164).

Schaaf permite assim compreender a simbologia contida na presença, em um encontro de mulheres rurais ligadas aos movimentos sociais, de uma agricultora grávida que trazia seu ventre fertilizado coberto por sementes coladas (PAULILO, 2010).

O texto em questão problematiza a questão da relação mulher-natureza, colocando que o feminismo propalado pelo MMC tem muitas interlocuções dessa dupla, com um viés religioso, a partir da Teologia da Libertação ${ }^{20}$. É importante, no entanto, situar que esse texto retrata o Movimento de Mulheres Camponesas a partir do sul do país e que sua pesquisa foi realizada até 2010, ou seja, tem um recorte específico que não integra os últimos cinco anos de caminhada no movimento.

Nesses últimos quase cinco anos, a questão do "feminismo camponês" tem sido objeto de grande problematização dentro do movimento, de modo que gostaríamos de nos deter um pouco sobre essa temática a fim de situar melhor o MMC dentre os movimentos feministas e a sua visão sobre a transformação da situação das mulheres.

Para cumprir essa tarefa, faremos uso de quatro textos de três autoras diferentes: Joan Scott, a partir dos textos "Gênero: uma categoria útil de análise histórica" (1991) e "Género: ¿Todavía una categoría útil para el análisis?” (2011); Judith Butler, a partir do texto

\footnotetext{
${ }^{20}$ Segundo a própria Paulilo: “A Teologia da Libertação é uma corrente teológica que reúne diversas igrejas cristãs e foi desenvolvida no Terceiro Mundo e na periferia dos países ricos a partir dos anos 1970. Está baseada na opção pelos pobres e apoia-os na luta contra a pobreza e contra o desrespeito aos direitos sociais. Desenvolveu-se inicialmente na América Latina e, na busca de uma visão das desigualdades à luz da fé cristã, recebe influência das Ciências Sociais e, em especial, de algumas correntes marxistas" (2010, nota 27, p. 932).
} 
"Fundamentos Contingentes: o feminismo e a questão do "pós modernismo"” (1998); e NicoleClaude Mathieu, a partir do texto "Identidad sexual/sexuada/ de sexo?" (1989/pub. 2005/rep.), confrontando-os com falas das lideranças do Movimento de Mulheres Camponesas, bem como de textos de sua produção.

Os textos servirão de apoio não somente para responder à provocação acima colocada sobre essencialismos, mas mesmo para compreender um pouco do universo dos estudos de gênero e sexo e instrumentalizar a nossa análise de discurso.

\subsubsection{Contribuição das chamadas pós-estruturalistas à análise}

Joan Scott se tornou célebre no Brasil a partir da tradução do texto "Gênero: uma categoria útil de análise histórica", em $1991^{21}$, realizada pelo SOS Corpo ${ }^{22}$, tornando-se referência para a utilização do conceito de "gênero" e, consequentemente, para grande parte dos estudos que versassem sobre as temáticas "mulheres" e "sexualidade", dentre outras, e de análise dos movimentos feministas.

Não tomaremos o conceito de gênero de Scott como categoria primordial para o trabalho, mas o de "relações sociais de sexo", como explicaremos melhor abaixo, mas o texto tanto faz um apanhado interessante sobre a teorização sobre sexo/gênero quanto traz uma original visão sobre relações de poder e gênero. Desse modo, existem pontos do discurso de Scott que temos a responsabilidade de elencar, dada a importância do texto como amparo para análises no mesmo universo em que trabalhamos.

Scott visita o tema em vários artigos e trabalhos, mas tomaremos dois textos que consideramos emblemáticos pelos problemas que trazem: o primeiro é o já mencionado "Gênero: uma categoria útil de análise histórica" (1991) e o outro é o "Género: ¿Todavía una categoría útil para el análisis?” (2011).

Scott inicia o primeiro ensaio lançando-se ao desafio de questionar a categoria gênero a partir da perspectiva de historiadora. O conceito serviria aos estudos históricos? Para responder

\footnotetext{
${ }^{21}$ O texto original é de 1989.

${ }^{22}$ SOS Corpo é uma das Organizações Não Governamentais (ONG) feministas mais antigas do Brasil (fundada em 1981, em Recife, PE) e é grande referência não somente em âmbito nacional, mas também internacional.
} 
à própria pergunta, passeia sobre o uso que a categoria tem alcançado ao longo de sua caminhada, identificando o caráter polissêmico que assumiu e elaborando críticas aos usos e teorizações sobre o termo.

Dentre os vários significados que o significante tomou ao longo de sua trajetória, Scott identifica que o termo "gênero" surge em meio a um esforço primeiro de criar uma categoria que dissesse que a submissão das mulheres não é decorrente de sua natureza, como se acreditava, inclusive com respaldo científico e religioso, mas que essa posição havia sido socialmente manipulada. Nesse esforço, cria-se o sistema sexo/gênero.

Haveria, portanto, o "sexo", como dado biologicamente, e o "gênero", como construído. Nesse sentido, recorremos a Moraes (2000) para dar mais clareza à expressão "relações de gênero":

\begin{abstract}
Assim, a expressão "relações de gênero", tal como vem sendo utilizado no campo das ciências sociais, designa, primordialmente, a perspectiva culturalista em que as categorias diferenciais de sexo não implicam o reconhecimento de uma essência masculina ou feminina, de caráter absoluto ou universal, mas, diferentemente, apontam para a ordem cultural como modeladora de mulheres e homens. Em outras palavras, o que chamamos de homem e mulher não é o produto da sexualidade biológica mas de relações sociais baseadas em distintas estruturas de poder. A categoria gênero ressalta a dimensão "flutuante" do ser homem e do ser mulher e, nessa medida, precisa recorrer a outras teorias para dar conta desta situação de amálgama entre o ser biológico e o ser social (p. 96).
\end{abstract}

Scott identifica, por outro lado, que "gênero" acabou se tornando, dentro da academia, sinônimo para "mulheres", como forma de dar maior legitimidade, a partir de uma pretensa neutralidade sobre os estudos que seriam realizados, já que havia uma preocupação de se separar os estudos ditos científicos dos estudos "políticos" das feministas.

No seu uso recente mais simples, "gênero" é sinônimo de "mulheres". Livros e artigos de todo o tipo, que tinham como tema a história das mulheres substituíram durante os últimos anos nos seus títulos o termo de "mulheres" pelo termo de "gênero". Em alguns casos, este uso, ainda que referindo-se vagamente a certos conceitos analíticos, trata realmente da aceitabilidade política desse campo de pesquisa. Nessas circunstâncias, o uso do termo "gênero" visa indicar a erudição e a seriedade de um trabalho porque "gênero" tem uma conotaçãomais objetiva e neutra do que "mulheres". O gêneroparece integrar-se na terminologia científica das ciências sociais e, por conseqüência, 
dissociar-se da políica - (pretensamente escandalosa) - do feminismo. Neste uso, o termo gênero não implica necessariamente na tomada de posição sobre a desigualdade ou o poder, nem mesmo designa a parte lesada (e até agora invisível) (SCOTT, 1991, p. 6).

Dentro desse campo de pesquisa, os historiadores lançam-se a descrever quais as funções e posições que a mulher ocupou através dos tempos e civilizações. Desde logo, Scott critica essas visões ditas descritivas do "gênero", que se atém a identificar que foram construídas socialmente funções e modos de estar no mundo diferenciados para homens e mulheres, mas não vão além. Não contribuem para uma construção teórica que enfrentasse as desigualdades. Scott desafia os(as) historiadores(as) e estudiosas(os) a avançar, com a finalidade clara de empreender uma transformação da realidade.

Mesmo se nesse uso o termo "gênero" afirma que as relações entre os sexos
são sociais, ele não diz nada sobre as razões pelas quais essas relações são
construídas como são; ele não diz como elas funcionam ou como elas mudam.
No seu uso descritivo o "gênero" é portanto um conceito associado ao estudo
das coisas relativas às mulheres. O "gênero" é um novo tema, novo campo de
pesquisas históricas, mas ele não tem a força de análise suficiente para
interrogar (e mudar) os paradigmas históricos existentes (SCOTT, 1991, p. 8).

Após realizar a crítica ao uso meramente descritivo do termo, Scott passa então a relatar as tentativas de teorias que se esforçam para ir além dessa postura, dividindo-as em três posições: a das teóricas do patriarcado, a de teóricas com tradição marxista, mas com compromisso com a crítica feminista, e outras, divididas entre o pós-estruturalismo francês e as teorias anglo-americanas das relações de objeto, que se amparam nas várias escolas de psicanálise para explicar a produção e a reprodução da identidade de gênero do sujeito.

Não concordamos de todo com as críticas lançadas por Scott a respeito das marxistas e do uso do conceito do patriarcado, como veremos mais à frente, mas ela traz análises muito interessantes acerca da problemática do essencialismo em vários pontos do texto, por exemplo, quando critica que as ditas teóricas do patriarcado, que exemplifica com base em Catherine Mackinnon e Firestone, centram seu debate em desigualdades existentes a partir de diferenças físicas, naturais e portanto imutáveis: 
(...) que a dominação venha na forma da apropriação masculina do labor reprodutivo da mulher, ou que ela venha pela reificação sexual das mulheres pelos homens, a análise baseia-se na diferença fúsica. Toda a diferença física tem um caráter universal e imutável mesmo quando as teóricas do patriarcado levam em consideração a existência de mudanças nas formas e nos sistemas de desigualdade no gênero. Uma teoria que se baseia na variável única da diferença física é problemática para os(as) historiadores(as): ela pressupõe um sentido coerente ou inerente ao corpo humano - fora qualquer construção sócio-cultural - e portanto, a não historicidade do gênero em si (SCOTT, 1991, p. 10).

Ou quando descreve as preocupações que atingiam as feministas marxistas em negar o essencialis mo:

Os primeiros debates entre as feministas marxistas giravam em torno dos mesmos problemas: a rejeição do essencialismo daqueles que defendem que "as exigências da reprodução biológica" determinavam a divisão sexual do trabalho pelo capitalismo; o caráter fútil da integração dos "modos de reprodução" nos debates sobre os modos de produção (que reprodução permanece uma categoria oposta e não tem um estatuto equivalente ao de modo de produção); o reconhecimento que os sistemas econômicos não determinam de forma direta as relações de gênero e que de fato a subordinação das mulheres é anterior ao capitalismo e continua sob o socialismo; a busca, apesar de tudo, de uma explicação materialista que exclua as diferenças físicas e naturais (SCOTT, 1991, p. 11).

$\mathrm{Ou}$, ainda, quando identifica que o movimento feminista sempre tendeu a lutar contra o binarismo homem/mulher (a autora levanta essa lebre quando rebate os estudos que relaciona m psicanálise e gênero, tratando a sexualidade a partir de categorias binárias que remetem ao masculino e ao feminino (ou a homens e mulheres?)):

Precisamos rejeitar o caráter fixo e permanente da oposição binária, precisamos de uma historicização e de uma desconstrução autêntica dos termos da diferença sexual. Temos que ficar mais atentas às distinções entre nosso vocabulário de análise e o material que queremos analisar. Temos que encontrar os meios (mesmo imperfeitos) de submeter, sem parar, as nossas categorias à crítica, nossas análises à autocrítica. Se utilizarmos a definição da desconstrução de Jacques Derrida, esta crítica significa analisar no seu contexto a maneira como opera qualquer oposição binária, revertendo e deslocando a sua construção hierárquica, em lugar de aceitá-la como real, como óbvia ou como estando na natureza das coisas. Em certo sentido as feministas, semdúvida, sófizeram isto durante anos. Ahistória do pensamento 
feminista é uma história de recusa da construção hierárquica da relação entre masculino e feminino; nos seus contextos específicos à uma tentativa de reverter ou deslocar seus funcionamentos. Os(as) historiadores(as) feministas estão atualmente em condições de teorizar as suas práticas e de desenvolver o gênero como uma categoria de análise (SCOTT, 1991, p. 18-19).

Essa perspectiva não essencialista e oposta ao binarismo coloca em xeque o sistema sexo/gênero no sentido de opor natureza/cultura, lutando contra qualquer forma de encalacrar homens e mulheres dentro de padrões. Diante disso, qual seria a proposta de utilização da categoria "gênero" lançada pela autora?

O núcleo essencial da definição baseia-se na conexão integral entre duas proposições: o gênero é um elemento constitutivo de relações sociais baseado nas diferenças pe rcebidas ${ }^{\mathbf{2 3}}$ entre os sexos, e o gênero é uma forma primeira de significar as relações de poder. As mudanças na organização das relações sociais correspondem sempre à mudança nas representações de poder, mas a direção da mudança não segue necessariamente um sentido único.

(...)

Como elemento constitutivo das relações sociais fundadas sobre diferenças percebidas entre os sexos, o gênero implica quatro elementos relacionados entre si: primeiro - símbolos culturalmente disponíveis que evocam representações múltiplas (freqüentemente contraditórias) -Eva e Maria, como símbolo da mulher, por exemplo, na tradição cristã do Ocidente, mas também mitos da luz e da escuridão, da purificação e da poluição, da inocência e da corrupção. (...) Segundo - conceitos normativos que colocam em evidência interpretações do sentido dos símbolos que tentam limitar e conter as suas possibilidades metafóricas. Esses conceitos são expressos nas doutrinas religiosas, educativas, científicas, políticas ou jurídicas e tipicamente tomam a forma de uma oposição binária que afirma de forma categórica e sem equívoco o sentido do masculino e do feminino. De fato essas afirmações normativas dependem da rejeição ou da repressão de outras possibilidades alternativas (...). A posição que emerge como dominante é, apesar de tudo, declarada a única possível.

(...)

Esse [o político] é o terceiro aspecto das relações de gênero. Alguns(mas) pesquisadores(as), notadamente antropólogos(as) reduziram o uso da categoria de gênero ao sistema de parentesco (fixando o seu olhar sobre o universo doméstico e na família como fundamento da organização social). (...) O gênero é construído através do parentesco, mas não exclusivamente; ele é construído igualmente na economia, na organização política e, pelo menos na nossa sociedade, opera atualmente de forma amplamente independente do parentesco. (...) O quarto aspecto do gênero é a identidade subjetiva. Conferências estabelecem distribuições de poder (um controle ou

${ }^{23}$ Sem grifo no original. 
um acesso diferencial aos recursos materiais e simbólicos), o gênero torna-se implicado na concepção e na construção do poder em si. (...)" (SCOTT, 1991, p. 21-23).

"Gênero", portanto, poderia ser identificada como "a forma primeira de significar relações de poder", colocando o par feminino da dicotomia como o lado que deva subserviência ao par masculino. Todo o conteúdo simbólico que sustenta as relações de poder se atrelam às construções sobre o feminino e o masculino e a homens e mulheres, mas principalmente às mulheres em última instância, colocando os seus corpos o local onde se materializam finalmente a submissão. A elas voltaremos mais à frente.

Adiantamos, no entanto, que acreditamos que, apesar das críticas lançadas por Scott às tentativas de articulação entre materialismo, marxismo e feminismo, as proposições acima são compatíveis com a crítica das autoras, que, também a partir do marxismo e do materialismo, procedem à análise da posição das mulheres na sociedade em uma perspectiva questionadora.

No segundo texto, “Género: ¿Todavía una categoria útil para el análisis?” (2011), Scott volta a questionar sobre a que o uso do termo "gênero" tem servido. Novamente, propõe críticas a um uso somente descritivo do termo e como sinônimo de mulheres:

La pregunta de si el género sigue siendo una categoria útil para el análisis ya sea histórico o de otro tipo - me parece que no depende de la palabra en si, sino de los usos críticos que seguimos haciendo de ella. Con demasiado frecuencia, "gênero" connota un enfoque programático o metodológico en el cual los significados de "hombre" o "mujer" se toman como fijos; el objetivo parece ser describir roles diferentes, no cuestionarlos. Creo que género sigue siendo útil sólo si va más allá de este enfoque, si se toma como una invitación a pensar de manera crítica sobre cómo los significados de los cuerpos sexuados se producen en relación el uno con el otro, y cómo estos significados se despliegan y cambian. El énfasis deberia ponerse no en los roles asignados a las mujeres y a los hombres, sino a la construcción de la diferencia sexual en si (SCOTT, 2011, p. 98).

Scott, portanto, vai além em outro tema e traz de forma mais clara a própria problemática do sistema sexo/gênero que identifica o sexo como "natural", levando-nos mais a fundo em relação a questionamentos acerca de uma essência feminina. Em um sutil diálogo com autoras como Donna Haraway e Judith Butler ou, em tom mais claro, com Denise Riley, Scott discute que o "sexo" e os significados sobre o corpo, o biológico também são socialmente construídos: 
La idea de construcción cultural se basaba en la noción de que podía distinguirse cuidadosamente entre el sexo y el género, ya que el primero se refería a la biología y el segundo a la cultura. Algunas críticas (Judith Butler, Donna Haraway), señalaron que la distinción era falsa, ya que si el género podía ser construido culturalmente, lo mismo podía hacerse con los significados biológicos del sexo. De hecho, era el género el que le atribuía a la biología su significación supuestamente innata (SCOTT, 2011, p. 95).

E que, apesar de um esforço descritivo identificando que existem mulheres diversas, a partir da posição que ocupam na sociedade em decorrência de sua cor, classe, nacionalidade, entre outros fatores, não se superou, a contento, o problema do biológico como natural:

No es que a las mujeres no se les dá una historia, claro que se les dá. Las ideas acerca de ellas se dice que cambian, como lo hacen las experiencias; éstas varían en el tiempo y de acuerdo a la clase, la etnicidad, la cultura, la religión y la geografía. La abundante literatura sobre la historia social de las mujeres está llena de importantes distinciones que insisten en la particularidad de las mujeres obreras o campesinas, lesbianas o medievales, o judías o afroamericanas, o musulmanas o latinas, o europeas del este o africanas. Pero por más que tomen en cuenta las vidas cotidianas de poblaciones diversas, estas diferencias dan por supuesta una "continuidad subyacente de mujeres reales sobre cuyos cuerpos constantes danzan descripciones aéreas y cambiantes" (Riley, 1988, p. 7). Paradójicamente, la historia de las mujeres ha mantenido a las "mujeres" fuera de la historia. Y el res ultado es que "las muje res" como un fenómeno natural se reins cribe, aún cuando afirmamos que ellas se construyen discursivamente. (...) Mientras las "mujeres" sigan "formando un telón de fondo pasivo para concepciones cambiantes de géne ro" (ibid.), nuestra his toria de scansará en una base biológica que las feministas - al me nos teóricamente - quie ren cuestionar ${ }^{24}$ (SCOTT, 2011, p. 98).

Mas essa visão não colocaria um problema para o próprio feminismo? Se se deve questionar a categoria "mulheres", a partir de funções e uma posição comum na sociedade, quem seria o sujeito do feminismo?

No hay una esencia de ser mujer (o de ser hombre) que aporte un sujeto estable para nuestras historias; sólo existen interaciones sucesivas de una palabra que no tiene un referente fijo y por lo tanto no significa siempre lo mismo. Fue la política feminista la que llevó a "las mujeres" a ser vistas como un objeto de investigación histórica. Pero, irónicamente, el proyecto de crear un sujeto para

${ }^{24}$ Sem grifo no original. 
el feminismo contemporáneo (una colectividad activa, que protesta, afirma sus derechos, que busca emanciparse de la opresión) tendió a difuminar las líneas de diferencia, ya sean temporales, culturales o sociales (SCOTT, 2011, p. 99).

A solução encontrada é de se compreender que o sujeito "mulheres", erigido sob o manto do feminismo, é uma construção, uma ficção, uma categoria que atende a perspectivas de transformação que coloquem em xeque o próprio "ser mulher" e o "ser homem".

Más bien, se apelaba a los intereses y las experiencias específicas que, en un momento particular, se organizaba bajo el signo de "mujeres". Las preguntas eran cómo y cuándo sucedía esto y bajó qué condiciones. Para entender el feminismo (en sus manifestaciones actuales y las históricas) había que pensarlo como una intervención estratégica en un conjunto de discursos que no estaban restringidos a las "mujeres".

(...)

La idea era que el sujeto actual del feminismo (nuestra colectividad) no podía proyectarse retrospectivamente ni lateralmente. El feminismo global es una unidad imaginaria, una visión política, no una entidad que pre-exista a su articulación (SCOTT, 2011, p. 99-100).

Segundo uma perspectiva pós-estruturalista evidenciada por $\operatorname{Scott}^{25}$, portanto, a essencialidade de sujeitos universais e, dentre deste parâmetro, a categoria "mulher" como ser oposto ao homem e oprimido por este, foi colocada em xeque porque obscurecia que existiam mulheres diferentes nesse meio que possuíam classe social, raça-etnia, origem, idade e sexualidade diversas. Um tensionamento no sentido de universalização, em vez de promover a unificação do movimento, estaria, pois, a operar contra as lutas a partir do ponto em que estava a silenciar vozes.

\footnotetext{
${ }^{25}$ Segundo Butler (1998, p. 16), quando enuncia sua compreensão sobre "pós-estruturalismo”: “(...) se há um argumento válido naquilo que eu entendo melhor como pós -estruturalismo, é que o poder permeia o próprio aparato conceitual que busca negociar seus termos, inclusive a posição do sujeito do crítico; e mais, que essa imp licação dos termos da crítica no campo do poder não é o advento de um relativismo niilista incapaz de oferecer normas, mas ao contrário, a própria pré-condição de uma crítica politicamente engajada. Estabelecer um conjunto de normas que estão acima do poderou da força é em si mesmo uma prática conceitual poderosa e forte que sublima, disfarça e amplia seu próprio jogo de poder, recorrendo a tropos de universalidade normativa. E a questão não é acabar com seus fundamentos, ou mesmo defender uma posição que se classifica como antifundamentalismo. Ambas as posições são versões diferentes de fundamentalismo e da problemática cética que engendram. Em vez disso, a tarefa é interrogar o que o movimento teórico que estabelece fundamentos autoriza e o que precisamen te exclui ou priva de direitos". In: BUTLER, Judith. Fundamentos contingentes. Cadernos Pagu, v. 11, p. 11-42, 1998. Disponível em: 〈http://www.bibliotecadigital.unicamp.br/document/?code=51196>. Acesso em: $1^{\circ}$ nov. 2014.
} 
O que fazer, então? Qual seria a saída possível?

Judith Butler, no texto 'Fundamentos contingentes: o feminismo e a questão do pósmodernismo" (1998), trabalha questões semelhantes e, estabelecendo críticas ao essencialis mo, não desconsidera a possibilidade de utilização tática (palavra nossa) de políticas de identidade como forma de articulação de grupos, no caso, as mulheres, em torno de pautas que as interessem.

No feminismo, parece haver uma necessidade política de falar enquanto mulher e pelas mulheres, e não vou contestar essa necessidade. Esse é certamente o modo como a política representativa funciona e, neste país, os esforços de lobby são virtualmente impossíveis sem recorrer à política de identidade. Assim, concordamos que manifestações, esforços legislativos e movimentos radicais precisam fazer reivindicações em nome das mulheres (BUTLER, 1998, p. 24).

Mas, no mesmo ponto, lança a necessidade de constante vigilância se esse "nós" provisoriamente estabelecido não está a silenciar vozes dentro de outros marcos de relações que foram construídas como hierárquicas, lembrando as questões de raça-etnia, classe, dentre outras.

Mas essa necessidade precisa ser reconciliada com uma outra. No instante em que se invoca a categoria mulheres como descrevendo a clientela pela qual o feminismo fala, começa invariavelmente um debate interno sobre o conteúdo descritivo do termo. (...) cada vez que essa especificidade é articulada, há resistência e formação de facções dentro da própria clientela que está supostamente unificada pela articulação de seu elemento comum. No começo da década de 1980, o "nós" feminista foi atacado com justiça pelas mulheres de cor que diziam que aquele "nós" era invariavelmente branco e que em vez de solidificar o movimento, era a própria fonte de uma dolorosa divisão (BUTLER, 1998, p. 26).

Ainda, ela diz:

Como poderemos fundamentar uma teoria ou política numa situação de discurso ou posição de sujeito que é "universal" quando a própria categoria do universal apenas começa a ser desmascarada por seu viés altamente 
etnocêntrico? Quantas "universalidades" existem e em que medida o conflito cultural pode ser compreendido como o choque de um conjunto de "universalidades" presumidas e intransigentes, um conflito que não pode ser negociado recorrendo a uma noção culturalmente imperialista do "universal", ou antes, que só se resolverá por esse recurso ao custo de violência? (BUTLER, 1998, p. 17)

Nesse ínterim, no que essas teorias colaboram com o explicar o "nós" identificado pelo Movimento de Mulheres Camponesas?

Somos mulheres camponesas: agricultoras, arrendatárias, meeiras, ribeirinhas, posseiras, bóias-frias, diaristas, parceiras, extrativistas, quebradeiras de coco, pescadoras artesanais, sem terra, assentadas... Mulheres índias, negras, descendentes de europeus. Somos a soma da diversidade do nosso país ${ }^{26}$.

A base do movimento, bem como sua representação entre as lideranças ${ }^{27}$, é, como podemos perceber pelo extrato do documento acima (fato que se confirmou na observação participante ${ }^{28}$ ), bem ampla e diversa, e a forma que entendem para manter a possibilidade da articulação é a de tender a respeitar a diversidade daquelas que o integram.

Uma base tão diversa poderia significar o engessamento de posicionamentos e ações do movimento ou a implicação de uma postura antidemocrática com o silenciamento de vozes (o que tenderia a enfraquecer o próprio poder de mobilização das bases).

No entanto, não foi isso que observamos. Nem a inatividade, nem o atropelo, mas uma perspectiva de construção de caminhos.

26 Descrição do "Quem Somos" pelo próprio MMC. Disponível em:
<http://www.mmcbrasil.com.br/site/node/43>. Acesso em: 5 set. 2014 .

27 A Direção Executiva da entidade, que, como o próprio nome já destaca, executa as determinações da Coordenação Nacional do Movimento, hoje é composta por 13 representantes, con templando as cinco regiões do Brasil (informações obtidas com integrantes da Secretaria em Brasília - DF). O funcionamento da organização está exposto no neste endereço eletrônico: 〈http://www.mmcbrasil.co m.br/site/node/46>. Acesso em: 10 fev. 2015.

${ }^{28}$ Embora a presença de mulheres do sul do país (e brancas) seja bastante intensa e numericamente superior (o que se explica pelo fato de uma grande parte da articulação do movimento ter começado lá), a presença de mulheres do norte e nordeste do Brasil e suas cores diversas é perceptível, o que se evidencia, no fato, de, por exemplo, o escritório de Brasília ser gerido por uma mulher amazonense e outra catarinense até o fim de 2014. 
Em uma tecitura trabalhosa, o movimenta sustenta a possibilidade de crítica e de pauta sobre questões delicadas e o enfrentamento de "verdades" do patriarcado ${ }^{29}$ bastante arraigadas entre as mulheres (e entre os homens), como um debate como o direito ao próprio corpo ${ }^{30}$, por exemplo, face a ainda forte religiosidade em uma perspectiva submissa das mulheres, a partir da visão dos fundamentalismos religiosos ${ }^{31}$.

Não é uma tarefa fácil, entretanto, e a metodologia do movimento é a de chegar até os temas mais complexos de forma transversa. São "pautas", embora não possam ocupar a centralidade no momento, dada à conjuntura das mulheres e a presença forte do tradicional is mo dentre a base.

Então não dá pra comprar uma briga assim. Hoje, por exemplo, nossa guerra é por que hoje? Pela produção de alimentação saudável. Combater os venenos, combater os transgênicos e os agrotóxicos.

Agora numa ofensiva como a que a gente tá a gente vai comprar briga com a questão da descriminalização do aborto? Nós, enquanto camponesas, não temos condições, na conjuntura atual de fazer essa discussão. Isso é uma pauta? É uma pauta. Mas hoje ela não pode ser central devido ao momento conjuntural que a gente tá vivendo (informação verbal) ${ }^{32}$.

Vivem, nesse sentido, com algumas dificuldades de fazer seu um discurso mais radical sobre sexualidade e direitos individuais. Em parte porque essas lutas têm uma cara e um discurso mais relacionado com os problemas enfrentados pelas mulheres brancas e com algum

\footnotetext{
${ }^{29}$ Entendendo patriarcado sinteticamente por: relação civil que dá direitos sexuais dos homens sobre as mulheres, praticamente sem restrição, como discutiremos mais à frente; configura um tipo hierárquico de relação que invade todos os campos da sociedade; tem uma base material; corporifica-se e representa uma estrutura de poder baseada tanto na ideologia como na violência. Ver: SAFFIOTI, Heleieth. Gênero e Patriarcado: a necessidade da violência. In: CASTILLO-MARTÍN， Márcia; OLIVEIRA, Suely de (Orgs.). Marcadas a ferro. Brasília: Secretaria Especial de Políticas Para as Mulheres, 2005. p. 62-63. ${ }^{30}$ Aqui, pensando no direito ao aborto e ao direito de ser sujeito e não objeto no relacionamento sexual, tendo a
possibilidade de dizer sim e, principalmente, dizer não. Retornaremos a esse assunto mais à frente.

${ }^{31}$ Aqui, destacamos que a religiosidade se expressa em uma perspectiva submissa, visto que mesmo diante das religiões monoteístas, que foram um marco para a retirada do poder das mulheres quanto à religiosidade, há uma crítica e propostas diferenciadas em relação à posição das mulheres na igreja, como o grupo das "Católicas Pelo Direito de Decidir". Sobre o monoteísmo e a inferiorização das mulheres na perspectiva religiosa, ver: LERNER, Gerda. La creación del patriarcado. Disponível em: 〈http://www.antimilitaristas.org/IMG/pdf/la_creacion_del_patriarcado_-_gerda_lerner-2.pdf 〉. 1986. Acesso em: 10 dez. 2013.

32 Entrevista concedida por Entrevistada "A". [ago. 2014]. Entrevistadora: Diana Melo Pereira. Brasília, 2014. arquivo .mp3 (26'11").
} 
poder aquisitivo dos espaços urbanos e o discurso sobre a violência específica que a mulher camponesa sofre por ser, repitamos, "mulher" e estar no espaço do "campo".

Para enfrentar o problema da violência, e, dentro dele, as questões que ocupam a centralidade na cidade, o Movimento de Mulheres Camponesas percebeu que era necessário, antes, entender o que de tradicionalismo ainda encerrava a liberdade das mulheres no campo e atuar a partir daí.

Sem chegar com fórmulas prontas, elas se dedicam enquanto movimento a perceber como e por que o espaço do campo ainda é carregado de tradições construídas pelo patriarcado e fortalecidas pela sua aliança com o capitalismo. O "feminismo camponês" decorre dessa descoberta junto com as mulheres e desenho de caminhos para a libertação:

E - Eu acho que o que mais define não seria diferenciar nem nada disso, mas é um feminismo que a gente chama de camponês, né? Que ele é muito voltado a partir da constituição e a identidade do ser camponês, da mulher camponesa nesse sentido. Então, como é que vocês têm uma linha de luta em defesa da mulher, mas a partir da identidade, do olhar de ser camponês, do que é ser camponesa. Entendendo, por exemplo, toda essa luta de modelo de agricultura, como isso influencia no ser mulher, no dia a dia, na forma de violência (informação verbal)

$\mathrm{P}$ - Você consegue identificar quais os tipos de violência mais frequentes que as mulheres mais comumente sofrem? (em específico, as mulheres camponesas)

E - A questão psicológica é muito forte. Ainda mais dentro da cultura do sul que é uma cultura muito em que a mulher já é constituída dentro de uma cultura que é pra submissão. Tem uma constituição cultural que se perpetua de familia de que a mulher tem que ter uma postura, vamos dizer entre aspas, uma postura reta, correta. Issono sul é uma coisa muito forte. Na minha região que é uma região muito de colonização alemã. Então, tem muito forte a questão da igreja também, da igreja católica, enfim, existe um perfil dado pra mulher que é um perfil mais submisso, mais omisso, mais de obediência, falando da forma mais correta. E aí que o homem é quem aparece, enfim, que é aquela coisa do chefe de família. Então essa questão mais também psicológica que eu sou incapaz, que eu que tenho que obedecer, de que eu que tenho que atender, de que eu que tenho que servir. Existe muito dentro dessa relação familiar e da sociedade também (informação verbal) ${ }^{33}$.

33 Entrevista concedida por Entrevistada "B”. [ago. 2014]. Entrevistadora: Diana Melo Pereira. Brasília, 2014. arquivo .mp3 (52'36"). 
Atuar com uma base diversa pede cuidado, zelo com as companheiras, para que se construa um movimento massivo. E mais do que a diversidade de sua base, o movimento entende sua identidade com plasticidade, enfrentando o patriarcado em que a sua própria identidade foi forjada, mas respeitando alguns princípios mais duros que relataremos mais à frente.

Com base em autores como Paulo Freire, e mesmo identificando-se com o materialis mo histórico marxista, são desafiadas e mesmo se colocam constantemente novas questões a partir do contato com outros movimentos sociais e feministas, sempre no sentido de refletir as possibilidades de libertação das mulheres e a construção de um mundo mais justo.

Em texto $^{34}$, Catiane Cinelli e Elisiane de Fatima Jahn (2011) assim se manifestam:

Sendo assim, afirmamos que a identidade das mulheres camponesas está em construção, não está pronta, acabada, e nem se dá de forma linear, mas entre muitos conflitos e contradições vivenciadas por estarem inseridas numa sociedade capitalista e patriarcal. (...) Desse modo, afirmamos que a identidade feminista se constitui especialmente ao questionar a cultura patriarcal, quando, de forma teórica e prática, as militantes se diferenciam frente às demais pessoas da sociedade. Essa diferenciação se dá ao mesmo tempo pessoal e coletivamente, por serem as mulheres organizadas que constituem o movimento, ou seja, um coletivo constituído de pessoas com objetivos comuns.

(...)

Percebemos que as identidades construídas são muitas, pois, ao mesmo tempo em que se identificam como mulheres lutadoras e feministas, se assumem também como cuidadoras e produtoras de alimentos, discutindo coletivamente a construção de novas relações entre os seres humanos e destes com a natureza.

Durante a observação participante, não observamos, no entanto, qualquer referência a um debate mais profundo sobre a construção do biológico e dos corpos. Nem esse tema apareceu durante as entrevistas. As menções a "mulheres" como seres com seios e capazes de ter filhos apareciam no conteúdo dos discursos, mas mesmo assim algumas ações mexiam profundamente sobre a imagem do que é ser mulher, mesmo de forma contraditória.

\footnotetext{
34 CINELLI, Catiane; JAHN, Elisiane de Fatima. A constituição de identidades camponesa e feminista no Movimento de Mulheres Camponesas. Revista Espaço Acadêmico, n. 117, ano X, fev. de 2011.
} 
A título de exemplo, colocamos uma campanha ${ }^{35}$ realizada a favor das escalpeladas, mulheres que perdem todo o couro cabeludo e até as sobrancelhas, vítimas dos eixos de barcos sem proteção para o motor. As mulheres do MMC rasparam os cabelos para doar em solidariedade àquelas que haviam perdido os seus, ou seja, para ajudarem mulheres desconhecidas, com as quais não possuem qualquer vínculo. O resultado para as doadoras foi o de ficar com cortes de cabelo que seriam tidos como tradicionalmente masculinos para doar em solidariedade e para fazer perucas para quem havia perdido todo o couro cabeludo.

Claro que aqui pode-se colocar que a solidariedade, o sacrificar-se por outrem que está mais enfraquecido é uma característica que foi cultivada como típica das mulheres. Mas, se paramos e refletimos, essa abnegação para os desconhecidos coloca-se em segundo lugar ao "compromisso" com a família e, principalmente, ao marido.

Com essa doação, não se pode negar o fato de que as mulheres do MMC enfrentaram um símbolo do patriarcado quando cortaram seus próprios cabelos. Um cabelo que não é só dela, mas do marido.

Um corpo que não the pertenceria... Mas que elas (re)tomam como seu e dispõem dele como acreditam que devem. Laços de solidariedade entre mulheres, que fortalecem a luta delas contra a dominação dos homens, contra o patriarcado no campo.

Chegamos, então, à conclusão de que o MMC começa a crítica aos papéis construídos culturalmente, mas esbarra em uma crítica mais profunda à construção social dos corpos? Não há uma resposta precisa a essa pergunta. Para trazer falas que exemplificam a complexidade da questão, sigamos com uma pequena retomada do texto de Nicole-Claude Mathieu, a seguir.

\subsubsection{O não essencialismo pela visão de uma das materialistas francófonas: uma crítica ao sistema sexo-gênero em Mathieu}

Nicole-Claude Mathieu, bem como outras autoras que traremos mais à frente, faz parte de um grupo ignorado (ou negligenciado?) por Scott em sua análise a respeito do feminis mo ${ }^{36}$.

\footnotetext{
35 Disponível em: <https://www.youtube.com/watch?v=GsvKSqW0hQg>. Acesso em: 10 fev. 2015.

${ }^{36}$ Quando trata do feminismo francês, tanto Scott como pensadoras como Butler, tendem a referir-se ao que ficou conhecido como o "French Feminism", composto por Julia Kristeva, Luce Irigaray, que se aventuraram por uma tentativa de aproximação entre a psicanálise e o feminis mo e são compreendidas pelas autoras do materialis mo francófono como essencialistas.
} 
Uma linha de pensadoras materialistas que lançam, desde a década de 1970/1980, questões relacionadas à crítica do sistema sexo-gênero e não se prendem, necessariamente, a explicações que passam pelo modo de produção da sociedade, tal como a historiadora enunciava em seu famoso texto quando escreveu a respeito do feminismo marxista.

As chamadas materialistas-francófonas são um grupo de feministas francesas que se reuniu em torno da revista Nouvelles Questions Féministes, criada em conjunto com Simone de Beauvoir, em 1981.

Elas declaram-se materialistas ${ }^{37}$, antiessencialistas e radicais e enxergam que, apesar de várias transformações com vistas à igualdade, as mulheres, enquanto grupo social, continuam sendo submetidas aos homens, compreendendo ambos os grupos como criações do patriarcado, que se apoia em um discurso sobre o que seria o sexo biológico:

Desde nuestra perspectiva materialista y anti-esencialista, "mujeres" y "hombres" no son otra cosa que dos categorías sociales, producidas por y dentro de relaciones de poder organizadas en un sistema social que se llama patriarcado. A pesar de todos los actuales discursos sobre la "igualdad" entre los sexos, las posiciones sociales de las mujeres y de los hombres siguen siendo jerarquizadas, y siguen obligando a las mujeres a estar en relaciones de dependencia material y simbólica con respecto a los hombres (FALQUET, 2004).

A identidade "radical" para elas, em início, serviu para diferenciar-se de outros grupos de feministas na França (as "diferencialistas" e as da tendência "luta de classes"):

\footnotetext{
${ }^{37}$ A despeito de Simone de Beauvoir, uma das fundadoras da revista, ser declaradamente ligada ao existencialismo: Declaram-se "materialistas" em lugar de "marxistas" propriamente, por acusar a falha da observação de Marx no capital se restringir ao trabalhador sexualizado. Marx falava do homem, no Capital, restando a necessidade de discussão do trabalho não remunerado. Vejamos Cristhine Delphy sobre o materialismo e o feminismo: "Ces concepts [les concepts de classe et d'exploitation] sont les concepts -clés du matérialisme auquel je vois deux fondements. Pour moi, le matérialisme est: «une théorie de l'histoire... où celle-ci s'écrit en termes de domination des groupes sociaux les uns par les autres» (Delphy, 1975b). La domination a pour ressort ultime l'exploitation. Ce postulat explique et/ou est expliqué par l'idée que la façon dont la vie est matériellement produite et reproduite est la base de l'organis ation de toute société, donc fondamentale aussibien au niveau individuel qu'au niveau collectif. Le marxisme est, de toute évidence, matérialiste: dans cette mesure, il est utilisable pour le féminisme. Dans la mesure où le matérialisme part de l'oppression, et inversement si on admet que partir de l'oppres - sion définit entre autres choses une approche matérialiste, «une science féministe... veut parvenir à expliquer l'oppression; pour ce faire elle doit en partir... elle débouche inévitablement surune théorie de l'histoire matérialiste» (Delphy, 1975b)". Disponível em: $\quad<$ http://www.feministes-radicales.org/wp-content/uploads/2010/11/Christine-Delphy-Unféminisme-matérialiste-est-possible.pdf>. Acesso em: 12 set. 2014.
} 
A corrente materialista universalista fundamenta-se no princípio da igualdade de todos os indivíduos perante os direitos humanos, conforme os princípios do Iluminismo marcados na filosofia política francesa, afirmando os valores laicos republicanos. "Esta corrente reivindica o acesso das mulheres à universalidade, supostamente neutra, mas que está na possessão dos homens, e o exercício de uma Razão que lhes foi negada" (Collin, 1995). Nesta perspectiva, o sexo não é natureza, mas construído a partir das relações de poder que submetem as mulheres aos homens, ele é sempre uma construção estrutural, que na corrente materialista é ancorada na divisão desigual do trabalho e na imposição à heterossexualidade.

(...)

A corrente diferencialista francesa desenvolvida nos anos 70 pelo grupo Psychépo, exceção do caso francês, afirma que "há dois sexos" dentro da mesma humanidade e que "o acesso à igualdade não é o acesso à identidade" (Collin, 2000), opondo-se às universalistas. Trabalhavam com questões simbólicas, culturais para explicar as diferenças entre os sexos; simpáticas ao maoísmo, propunham uma revolução cultural.

Construíram uma crítica à psicanálise freudiana e incluíram uma releitura crítica de Lacan, com influências da "Escola inglesa de Psicanálise".

(...)

Por outro lado, esta cisão se polarizou, conforme já nos referimos acima, com as feministas materialistas, que tinham à sua frente Christine Delphy, seguidora de Simone de Beauvoir. Deplhy considerava as diferencialistas essencialistas e antifeministas, já que para ela as diferenças sexuais eram construídas hierarquicamente e justificavam as desigualdades sociais; enquanto para as diferencialistas era uma identidade pré-social, dada pela natureza (SCAVONE, 2007, p. 11).

Mas, com o tempo, serviu-lhes para se distanciar das pesquisadoras de "gênero" e para assumir termos como "patriarcado" e "relações sociais de sexo", acreditando que estes tinham um caráter mais direto do que o "gênero" e evidenciaria que os homens (heterossexuais) possuem privilégios nesta sociedade sobre as mulheres e outros grupos:

Pero precisamente, a la vez que se da y se busca esta legitimación, los conceptos evolucionan sutilmente y se observa un progresivo desplazamiento de apelaciones y perspectivas explícitamente feministas para perspectivas de género. Si bien es cierto que la teoría sexo-género puede representar un avance en determinadas disciplinas y lugares, también puede significar un retroceso por su aspecto más light, y la falta de claridad con que a menudo se maneja. Es en este contexto que el debate sobre el uso de la palabra "radical" toma todo su significado (FALQUET, 2004). 
Passado esse preâmbulo, vejamos o que diz Nicole-Claude Mathieu acerca das relações sexo-gênero e sobre identidade.

No texto "Identidad sexual/sexuada/ de sexo? Tres modos de conceptualización de la relación entre sexo y género" (1989/pub. 2005/rep.), Mathieu sistematiza dados sobre relações entre sexo/gênero em sociedades ocidentais e não ocidentais, classificando-as em três linhas de pensamento, apontando o que seria considerado dentro da "norma" e o que (e como) seria compreendido o desvio/a subversão.

A explanação a seguir sobre o texto da autora vem-nos com duas funções. A uma, lançar linhas para compreendemos o alcance (e o limite) do que o Movimento de Mulheres Camponesas do Brasil identifica como opressão às mulheres, e o que tem construído como alternativa. A duas, em um esforço teórico de ampliar e dimensionar melhor um cenário sobre os estudos de sexo/gênero integrando as materialistas e suas contribuições para a elaboração de outros pontos de vista, visto que, no Brasil, os estudos têm sido hegemonizados a partir do pensamento das pós-estruturalistas estadunidenses.

Mathieu identifica, pois, três modos de conceitualização do sistema sexo/gênero: 0 primeiro, de "identidade sexual", em que o gênero traduz o sexo em uma correspondência homológica; o segundo, de "identidade sexuada", em que o gênero simboliza o sexo em uma correspondência analógica e o terceiro, de "identidade de sexo", baseada em uma consciência de classe, em que o gênero constrói o sexo em uma correspondência sociológica.

No primeiro modo, de "identidade sexual", em um viés individualista, o gênero teria a função apenas de traduzir o sexo, dado biologicamente, de forma que as fêmeas/mulheres teriam comportamento "feminino" e os machos/homens, comportamento "masculino". A autora identifica esse modo de pensamento como o padrão na sociedade ocidental.

Un primer modo de conceptualización del sexo se sitúa en una problemática que llamaré de identidad <<sexual〉>, basada en la consciencia individualista de la vivencia sico-sociológica del sexo biológico.

Se trata de una problemática de la adecuación (de la que resultan problemas de inadecuación) entre rasgos personales sico-sociales y rasgos biológicos. Se concibe el sexo biológico determinado, o a determinar.

El referente por lo tanto es una bipartición absoluta del sexo, a la vez natural y social. El $<<$ hecho de ser macho $>>$ (maleness) corresponde a lo masculino, el $<<$ hecho de ser hembra $>$ (femaleness), a lo femenino. El modelo es la heterosexualidad, concebida en Occidente como una expresión de la 
Naturaleza (o en otras sociedades como la expresión de un orden del mundo ya fijado).

(...)

El género traduce el sexo. Entre sexo y género, se establece una correspondencia homológica. La diferencia de los sexos se concibe como la fundadora de la identidad personal, del orden social y del orden simbólico (MATHIEU, 1989, p. 135).

Os "desvios" homossexuais e transexuais, nesse primeiro modelo, seguiriam também o padrão bicategórico, identificando nos casais homossexuais quem assumiria a função de gênero contrária à de seu sexo. Em outras palavras, mulheres "masculinizadas" e homens "afeminados" ou, no caso dos transexuais, a busca por uma necessária transformação "completa" (incluindo aí cirurgias e tratamento hormonais) para que o transexual se compreenda "de verdade" no sexo que correspondesse à sua psique e se enquadre nos padrões heterossexuais.

A nivel de la definición, la contradicción que representa la homosexualidad en esta perspectiva I se resuelve de una manera que puede parecer paradójica:

1. Por un lado, hay que continuar definiendo cada término de la relación entre los miembros de la pareja a través de lo biológico; de allí la definición simple: una pareja homosexual $=1$ mujer +1 mujer, o 1 hombre +1 hombre

(...)

2. Por otra parte, a la vez que se define la relación homosexual en términos biológicos, es necesario encontrar también en el plano sico-social la bipartición del modelo heterosexual de base. De ahíla idea común - y a veces puesta en práctica - que en una pareja homosexual, habrá una mujer $<<$ masculina $>>$ o un hombre $<<$ femenino $>$. En realidad, solo uno de los dos es considerado de hecho como homosexual y desviado [déviant]: el que no tiene (no tendría) el $\langle\langle$ rol $\rangle>$, o la $\langle<$ sicología $\rangle$, o el comportamiento sexual (por ejemplo en la oposición jerárquica <<activo/pasivo〉>) - es decir, el género de su sexo(MATHIEU, 1989, p. 135).

O detalhe, no caso dos transexuais, é que essa linha de pensamento consegue declarar "mulher" uma pessoa que "nasceu" "homem", desde que "ele" passe pelas transformações "necessárias"; mas resiste a declarar "homem" uma pessoa que "nasceu" "mulher", mesmo que essa pessoa se esforce em fazer uso da medicina e se comportar dentro dos padrões de comportamento identificados como masculinos. 
(...) un texto de Ines Orobio de Castro (1987) sobre la aprehensión teórica y el tratamiento asimétrico del transexualismo, dependiendo de si el sujeto quiere volverse hombre o mujer. Para un hombre-a-mujer, una vez descartado el diagnóstico de homosexualidad, se considerará que tiene una identidad de género <<mujer>> real; una mujer-a-hombre será considerada antes que todo como homosexual $<<$ masculina $>>$ más que como hombre... Parece que no se puede concebir una $<<$ verdadera $>>$ masculinidad en la mujer. Según la autora, la razón de esta actitud no sería tanto que es más fácil admitir que se adopte el estatus (inferior) de mujer, que el estatus (superior) de hombre. Esta perspectiva asimétrica le parece más bien vinculada a una <<evaluación diferente de la relación entre la orientación sexual y el sexo biológico: la práctica sexual de un hombre [es decir: activo/pasivo] siendo decisiva para su ser-macho (maleness), el cuerpo de una mujer para su ser-hembra (femaleness) >>.

(...)

Mi interpretación, que no contradice la de Orobio de Castro, es que dentro de la óptica sexualista de las sociedades occidentales, el sexo de la mujer es, sobre todo, un no-sexo masculino. De hecho, la mujer no tiene sexo, es un nomacho. Un hombre sin pene es entonces forzosamente una mujer, aunque el sexo artificial que le fabriquen no tenga nada que ver con un sexo femenino. Una mujer sin vulva ni vagina no puede ser un hombre porque el pene artificial no tiene nada que ver con un sexo masculino (MATHIEU, 1989, p. 138-139)

A observação participante e a análise das entrevistas com as lideranças do Movimento de Mulheres Camponesas permitiram identificar que há um trabalho de conscientização, a partir de técnicas ligadas à Educação Popular ${ }^{38}$, com tentativas de desnaturalização da posição e dos papéis que as mulheres camponesas ocupam na sociedade, mas as lideranças admitem que não há uma uniformidade na base (e nem em algumas lideranças) a respeito de limites (colocados por uma dita "natureza" feminina) para o debate.

No mesmo sentido, vemos Conte (2011):

Não se nega entretanto, que sofrem ação do patriarcado, sendo ainda negadas e inferiorizadas, contudo, conseguem reagir e, acima de tudo, em Movimento se dar conta de como a opressão acontece, como a reproduzem e como podem superá-la quando isso é possível. Uma das entrevistadas, inclusive, mencionava que essas transformações (da consciência crítica à ação) são as mais demoradas e, nem todas as mulheres do MMC chegam a esse patamar, pelo fato de exigir rupturas (p. 115).

\footnotetext{
38 São realizadas oficinas com as mulheres (e algumas vezes com grupos mistos) e, a partir de dinâmicas que possibilitam que as mulheres falem a partir de suas experiências e do que as angustiam, são problematizadas questões como o direito ao próprio corpo, a necessidade de que as mulheres participem das decisões acerca da família, do acampamento/as sentamento e da produção, a divisão sexual do trabalho e o peso dis so para as mulheres no campo, dentre outros temas.
} 
Nos debates, verificam-se ainda discursos que colocam uma justificativa divina, a natureza e uma conformidade com a posição da mulher na sociedade, como mães e responsáveis pelo encargo da família, por exemplo. O discurso é ainda reforçado pelas próprias políticas governamentais, conforme veremos a seguir ${ }^{39}$.

Quando falas problemáticas como essa surgem, no entanto, sempre que (e quando é) possível, são problematizadas. Percebeu-se também que algumas questões não são enfrentadas no mesmo momento em que são colocadas, de modo a não tolher a mulher que a tenha colocado. Recuos táticos, às vezes, são utilizados a fim de que se crie a ambiência necessária para o enfrentamento da questão.

A segunda forma de pensar (e se relacionar com) a divisão sexo/gênero é, segundo Mathieu, a visão do sexo ainda como "dado", mas o comportamento em torno dele como "construído" socialmente. A autora define essa problemática como identidade sexuada.

La persona no se ubica solamente de manera individual en relación a su sexo biológico, sino que la identidad personal está fuertemente vinculada a una forma de consciencia de grupo. El sexo no es vivido ya, al igual que en el modo I, únicamente como un destino individual anatómico que hay que seguir por medio de la identidad de género correspondiente, sino que el género es percibido como una especie de modo de vida colectivo. Aquí, se tiene consciencia de la imposición de comportamientos sociales a personas en base a su sexo biológico (<<grupo de los hombres $\rangle>/\langle<$ grupo de las mujeres $\rangle)$ (MATHIEU, 1989, p. 141-142).

Essa construção social em torno de um sexo "dado" pode ser mais ou menos questionada, problematizada e criticada, a depender do conteúdo crítico que possa ser lançado em respeito a funções que estão naturalizadas.

Dentro dessa perspectiva, segundo a autora, estaria compreendido o comportamento político que ela designa como "feminismo cultural", que tende a procurar uma revalorização do que foi relegado ao feminino (e às mulheres):

\footnotetext{
${ }^{39}$ Embora a Secretaria de Políticas para as Mulheres ligada à Presidência da República reúna importantes nomes de teóricas e integrantes de movimentos sociais feministas, de fato, o governo, tal como a sociedade, ainda se depara com discursos conservadores e mesmo reacionários e ações em disputa no que diz respeito aos direitos das mulheres.
} 
Para lo que llamo el feminismo cultural, el problema es que la mujer no es suficientemente reconocida y valorada; la <<cultura femenina $>>$ parece provenir de una especia esencia. Los enunciados-tipos de esta corriente son: $<<$ nuestra cultura está fuera de lo social $>>, o<<$ hay que hacer acontecer la mujer > (MATHIEU, 1989, p. 142).

A autora, ainda, enquadra parte do feminismo marxista dentro dessa perspectiva:

En el mismo modo de pensamiento [identidade sexuada], podríamos ubicar a algunas $<<$ feministas socialistas $>>0<<$ feministas marxistas $>>$ anglosajona $\mathrm{s}$ (en Francia, la tendencia llamada <<lucha de clases $>$ ). La idea es que se necesitaría corregir injusticias en el estatus respectivo de los hombres y de las mujeres, para llegar a una igualdad entre los roles de sexo que incluya un eventual mejoramiento de sus contenidos, un cambio en las $<<$ mentalidades〉>, pero sin mermar la solidaridad hombres-mujeres, considerada como necesaria para las luchas <<globales〉> (anticapitalistas, nacionalistas, etc.). El término que usan para su acción es significativo: lucha de las mujeres, y no lucha de los sexos (MATHIEU, 1989, p. 143).

O MMC aproxima-se muito do feminismo marxista nesse ponto, mesmo porque se identificam como socialistas, a partir de uma crítica ao modo de produção capitalista e suas consequências para a sociedade e, de modo especial, para as mulheres camponesas. Isso as coloca ao lado dos movimentos mistos em muitas pautas relacionadas às questões gerais que atingem homens e mulheres camponeses.

Essa aproximação, por outro lado, não tende a fazê-las recuar em seu discurso ou as impedem de, em alguns de seus documentos e em várias de suas posturas, identificarem com clareza que homens praticam violência contra as suas companheiras no relacionamento. Não fazem, pois, alusões ao machismo de forma abstrata e situam a participação dos homens no processo:

A violência é uma prática cada vez mais visível em todos os âmbitos da vida humana, causando muita dor, sofrimento e lágrimas, ferindo a dignidade e a vida de muitas pessoas. É sempre uma demonstração de poder contra uma pessoa, grupos, comunidades ou classe social e com impactos danosos para a humanidade. Contudo, ela se apresenta de forma diferenciada para homens e mulheres.

A violência masculina contra a mulher é fruto do modelo patriarcal de sociedade, onde as relações pessoais afetivas estão fundamentadas não nos 
sentimentos e no afeto, mas no princípio da propriedade, do controle e do domínio sobre a mulher. E, é isto que, em vias de regra, garante ao homem o poder de violentar uma mulher, uma vez que a considera sua propriedade.

A violência por parte do sistema capitalista patriarcal e a modernidade se expressam em todas as esferas da vida das mulheres e acaba se reproduzindo no cotidiano como algo natural. Esta naturalização traz consigo o domínio do homem sobre todos os aspectos da vida da mulher e sobre seu corpo que passa a ser encarado como um objeto que tem que servir e obedecer aos homens (VIA CAMPESINA, 2012). ${ }^{40}$

Há, pelo contrário, um avanço no enfrentamento a cada vez que a questão das mulheres é colocada abaixo da questão de "classe". E foi mesmo isso que justificou a criação de um movimento autônomo.

Os primórdios do movimento foram estabelecidos na década de 1980, contemporâneo a muitos outros movimentos de luta pela terra, tais como o Movimento dos Trabalhadores Rurais Sem Terra e a Comissão Pastoral da Terra e entende a luta que os unifica como primordial ${ }^{41}$, mas entende também que as questões das mulheres precisavam ser integradas nessa luta. A palavra de ordem "quando uma mulher avança, nenhum homem retrocede" marca bem a tentativa de fazer com que a questão das mulheres seja integrada em igual valor à perspectiva de transformação da realidade.

(...) há 30 anos atrás foi um período que também houve o surgimento de outros movimentos como o MST e outros movimentos, CPT... Elas [as mulheres que comporiam o MMC] faziam até parte da organização da Eclesial de Base, que é da CPT e tal... mas elas sentiam que nessa luta que se fazia pela terra, nessa luta que se fazia pelos direitos dos trabalhadores rurais, dos camponeses, que a luta das mulheres ficava sempre em segundo plano. Que não era uma prioridade lutar pelos direitos exclusivos das mulheres. Pela participação das mulheres. No caso, o movimento é pioneiro na luta, por exemplo, de reconhecer a trabalhadora rural como uma profissão que na época não era reconhecida. Então, elas sentiram que a luta tinha que ser a partir da organização e da luta das mulheres [ênfase] que esses direitos, que esse reconhecimento quanto protagonistas, como trabalhadoras do campo e produtoras de alimentos só seria possível a partir delas, das próprias mulheres organizadas. Então, foi dessa necessidade de colocar dentro da luta maior pela

\footnotetext{
40 Sem grifo no original.

41 Possuem até espaços de articulação de movimentos no campo em todo o mundo, como a Via Campesina (integram a Via Campesina 164 organizações, em 73 países, dentre elas, o MMC Brasil). Informação disponível em: <http://viacampesina.org/es/index.php/organizaciainmenu-44/los-miembros-main menu-71〉. Acesso em: 13 set. 2014.
} 
mudança de sociedade, pela reforma agrária, do acesso à terra e direitos, a necessidade de que as mulheres fossem vistas, fossem protagonistas e vistas e também protagonistas pelos direitos, pela luta por direitos. Foi nesse sentido foi que elas sentiram necessidade e começaram se organizar (informação verbal) ${ }^{42}$.

Voltaremos a essa questão mais à frente, mas de pronto indicamos que a disputa com os movimentos mistos, principalmente os homens desses movimentos, não é tão simples. A luta contra o silenciamento ou o menosprezo das questões referentes à igualdade, com ênfase na divisão das decisões políticas e econômicas com as mulheres, é difícil, porque significa perda de poder dos homens que integram aqueles espaços e um questionamento profundo da organização da dinâmica social.

Outro ponto merece nota no texto de Mathieu e que nos conclama a tecer mais considerações acerca das relações mulheres camponesas/natureza, voltando ao debate inicial do essencialis mo no MMC:

Dentro de la misma lógica (aunque a veces enla tendencia opuesta) ${ }^{43}$, se hallan los intentos de develar los poderes <<reales $>>$ de las mujeres que la ciencia masculina (u occidental) habría ocultado, o las referencias a las diosas-madres y a un supuesto matriarcado originario: hay que re-conocer y valorar a las mujeres, La Mujer (MATHIEU, 1989, p. 143).

De fato, a mística do MMC valoriza os conhecimentos acumulados pelas mulheres, tendendo a enfatizar a relação mulher/feminino/natureza:

\section{Mís tica e simbologia do MMC}

O nosso Movimento de Mulheres Camponesas é fruto de uma caminhada de luta pela libertação das mulheres que encontra suas raízes na luta popular. Neste sentido podemos afirmar que a Mística do MMC encontra sua razão de ser no desejo de justiça e felicidade que nos anima na luta, no trabalho de base. A terra, a água, o fogo e ar são elementos que dão significados à mística da vida.

\footnotetext{
42 Entrevista concedida por Entrevistada "B" [ago. 2014]. Entrevistadora: Diana Melo Pereira. Brasília, 2014. arquivo .mp3 (52'36").

43 A tendência oposta à que a autora se refere é a lógica feminista marxista apontada acima.
} 
$(\ldots)$

Como mulheres camponesas, lutadoras, militantes e dirigentes de nosso Movimento, na alegria, na confraternização, devemos nos entusiasmar pela vida, pelo feminino, pela natureza. ${ }^{44}$

Nas místicas, a relação sementes, vida, mulheres grávidas é também muito forte. De fato, o MMC valoriza a mulher enquanto "próxima" à natureza e detentora de conhecimentos ancestrais. Isso é realizado por outros movimentos de mulheres na América Latina que ressignificam a própria "natureza", em um movimento contrário ao realizado pela ciência moderna. Em lugar de um domínio da natureza (e das mulheres), vê-se a necessidade de uma nova forma de valorização e convívio entre ser humano e outros seres vivos ou não vivos.

Figura 1 - Mística de Abertura do I Encontro Nacional do MMC Brasil

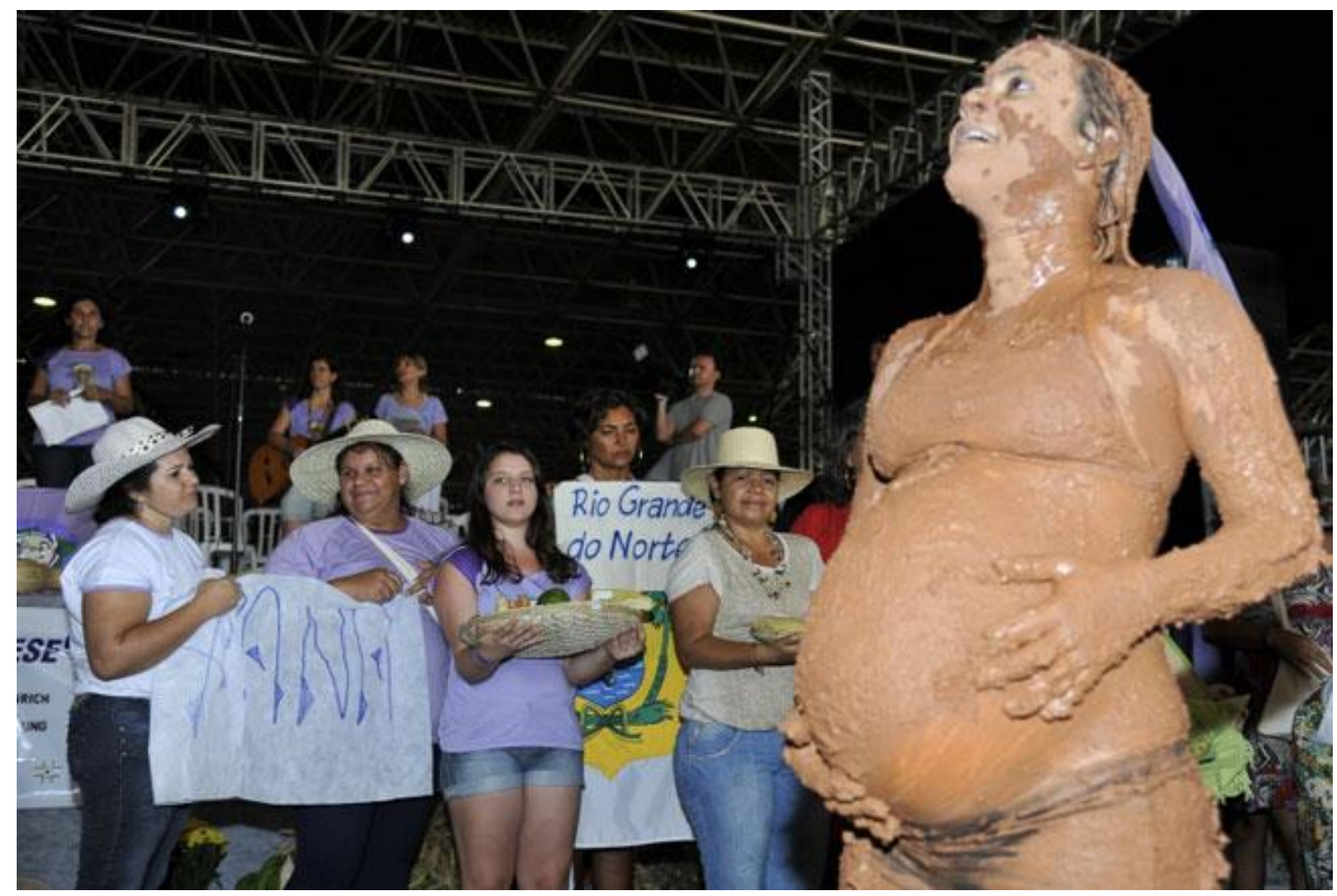

Foto: Fabio Rodrigues Pozzebom/ABr ${ }^{45}$.

\footnotetext{
${ }^{44}$ Disponível em: <http://www.mmcbrasil.com.br/site/node/43>. Acesso em: 2 jan. 2015.

45 Disponível em: <http://bagarai.com.br/noticias/fotos-encontro-nacional-do-movimento-de-mulherescamponesas.html>. Acesso em: 30 abr. 2014.
} 
Acontece que, mesmo diante dessa questão, a análise de que o MMC é essencialista seria muito apressada e mesmo equivocada, a nosso ver.

De fato, dentre as bases e as lideranças há quem vislumbre a detenção de conhecimentos sobre as sementes, ervas, cuidado com as crianças e idosos como um poder feminino, um poder inato das mulheres que deva ser valorizado, mas, nas práticas do $\mathrm{MMC}$, enquanto movimento, há sempre a abertura para questionamento da posição das mulheres e de qualquer imposição que thes tire a liberdade de decidir sobre suas próprias vidas.

Há, na verdade, não somente uma valorização desse conhecimento e práticas das mulheres contra um conhecimento científico masculino, mas há uma conclamação de toda a sociedade para que mude suas práticas de relacionamento com a natureza e de cultivo da terra. Elas não defendem a exclusividade das mulheres nessa posição, elas querem que os homens dividam com elas esse conhecimento e essas tarefas.

Mas, aqui, frisamos a palavra "dividir". Não é "tomar pra si” e nem "dar" para os homens a atribuição. O que o movimento não se escusa de disputar é que, valorizado o conhecimento e as práticas que as mulheres detenham, que elas não sejam alijadas do processo, prática que os homens temos homens têm realizado ao longo dos séculos, com o apoio do patriarcado. Retomaremos essa questão mais à frente.

Ponto caro à discussão do movimento feminista é a questão da heteronormatividade, questão que sentimos também necessidade de tocar a fim de continuar o diálogo entre "campo", "objeto-sujeito" do trabalho e "cidade", da onde o olhar para esse "objeto-sujeito" é dirigido.

Retornando à Mathieu, acerca da visão sobre heteronormatividade, e o modelo II, da identidade sexuada:

En lo que se refiere a la relación entre lo biológico y lo social, se concibe en esta perspectiva II la adecuación entre lo social y lo biológico (es decir, el modelo de la diferencia heterosocial) no tanto como <<natural > o basada en un orden del mundo cualquiera que sea (como en la primera perspectiva), que como necesaria para el buen funcionamiento de la sociedad. Se trata, podría decirse, de una perspectiva pragmática, diferente a la perspectiva idealista del modo I (MATHIEU, 1989, p. 145). 
Como já comentamos, no período da observação participante não se constatou que a temática fosse colocada em pauta. O MMC não toca na questão e a base parece mesmo reproduzir a naturalização do modelo I, tendo a heterossexualidade naturalizada.

Em conversas informais com as lideranças, no entanto, colocou-se que o tema já está sendo pensado, embora seja ainda muito delicado de ser enfrentado como pauta para o debate, vislumbrando que mesmo dentre a direção o tema pode ser visto com estranhamento.

Por outro lado, algumas mulheres do movimento já se identificam fora do padrão heteronormativo e mesmo parte das lideranças começam a apoiar a pauta LGBTTT, participando de passeatas, por exemplo. Temos a impressão de que não se pode descartar de todo de que, futuramente, a pauta seja integrada para a problematização e questionamento do patriarcado dentro do MMC.

Na configuração do "modo III" de pensamento acerca da relação sexo/gênero, Mathieu traz teorias e compreensões que colocam em suspenso, e mesmo questionam, a noção biológica do sexo e focam na ideia de que o gênero é quem "constrói” o sexo. O sexo é, portanto, antinatural e determinado política e socialmente e, como tal, pode ser objeto de análise materialista.

A autora chama atenção que os tipos de gênero, como padrões de comportamento, são ideais, não havendo ninguém que atenda ao padrão feminino ou masculino por completo e, quanto à ideia do aspecto "natural" do sexo (que o diferenciaria do "gênero", esse social), retoma a ideia, já bem conhecida, de que não há um ser humano em "estado natural". Teríamos, pois, não uma "diferença", mas uma "diferenciação" construída socialmente entre os "sexos" e, nesse ponto, a autora reforça "sexo" e não "gênero", explicando que nessa linha de pensamento:

(...) la atención se reorienta, en las ciencias sociales, de la construcción cultural del género hacia la construcción cultural del sexo, y en especial de la sexualidad.

En lo que se refiere a las relaciones entre lo biológico y lo social, se pueden considerar dos aspectos:

1. ¿En qué medida las sociedades usan la ideología de la definición biológica del sexo para construir la <<jerarquía〉> de género? - la cual está basada a su vez sobre la opresión de un sexo por el otro.

2. ¿En qué medida las sociedades manipulan la realidad biológica del sexo con el fin de obtener esta diferenciación social? (MATHIEU, 1989, p. 158). 
Ou aqui:

El género, es decir la imposición de un heteromorfismo de los comportamientos sociales, ya no es concebido entonces en el modo III como el marcador simbólico de una diferencia natural, sino como el operador de poder de un sexo sobre el otro - notándose aquí que, siendo la clase de las mujeres ideológicamente (y materialmente) definida en cualquier sociedad por su sexo anatómico, la clase de los hombres lo es objetivamente por el suyo.

(...)

Volvemos a hallar aquí la superposición entre sexo biológico y sexo social de la que hablábamos al principio de este artículo, pero concebida como un hecho social, histórico, debido a la explotación material de las mujeres y a la ideología opresiva del género, y (contrariamente al modo II) no necesariamente <<imprescindible〉> para la reproducción de las sociedades (MATHIEU, 1989, p. 168).

E mais à frente, no texto que escolhemos como referência, retoma que a utilização da terminologia "gênero" tem servido a retirar o peso de quem é explorado por quem. Se há homens e mulheres em relação, heterossexual ou não, e se seus comportamentos são produzidos socialmente, as mulheres têm permanecido na base, no grau mais baixo da hierarquização dos gêneros (até nos casos em que um "terceiro sexo" é admitido) e, com base no seu sexo "social", tem thes sido restrita a liberdade.

Entiendo por sexosocial a la vez la definición ideológica que es dada del sexo, particularmente del de las mujeres (lo que puede recubrir el término $<<$ género〉>) y los aspectos materiales de la organización social que utilizan (y también transforman) la bipartición anatómica y fisiológica.

El sexo - en sus aspectos de idea [idéels]; para retomar una expresión de M. Godelier, así como en sus aspectos materiales - funciona efectivamente como un parámetro en la variabilidad de las relaciones sociales concretas y de las elaboraciones simbólicas - lo que la actual tendencia (en particular en los Women's Studies anglosajones) a utilizar exclusivamente y a cada paso el término de <<género〉> tiende a ocultar, haciéndole perder parte del valor heurístico que le habíamos querido $\mathrm{dar}^{46}$. Ahora se escucha hablar de $<<$ relaciones sociales de producción de género〉> (gender relations of production), pero a pesar del traspaso de género e incluso de sexo, estas relaciones de producción consisten en la explotación de las mujeres. Sin duda

\footnotetext{
${ }^{46}$ No mesmo sentido, está a reivindicação do termo "patriarcado" em lugar de "gênero", a fim de evidenciar que há uma situação concreta de desigualdade e hierarquia que privilegia os homens, em detrimento das mulheres. Ver: SAFFIOTI, Heleieth. Gênero e Patriarcado: a necessidade da violência. In: CASTILLO-MARTÍN; Márcia; OLIVEIRA, Suely de (Orgs.). Marcadas a ferro. Brasília: Secretaria Especial de Políticas Para as Mulheres, 2005.
} 
existen géneros $<<$ hombre-mujer $>>$, pero en la base y en el peldaño más bajo de la escala de los géneros, lo que efectivamente hay son hembras: sexo social <<mujer>> (MATHIEU, 1989, p. 168).

Em última instância, temos a perceber que o Movimento de Mulheres Camponesas tende a fazer algumas análises e construções que se enquadram na profundidade crítica do modelo III proposto por Mathieu, principalmente no que diz respeito às questões e críticas que o MMC faz relacionadas à construção histórica da divisão sexual do trabalho e de que, materialmente, tem condicionado as mulheres a uma posição subalterna no campo. Embora em muitos momentos se detenha no "modelo II", seu posicionamento está em caminhos de maior radicalidade. 


\section{CAPÍTULO 2: MULHER CAMPONESA E DIVISÃO SEXUAL DO TRABALHO: PATRIARCADO E CAPITALISMO NO CAMPO}

No capítulo anterior, trouxemos à baila que, dentro do conceito "camponesa", há uma significativa multiplicidade de vozes e de formas de significar o mundo. Mas quais as condições de realização dessa reunião de mulheres? Que motor desencadeia os processos necessários para a articulação de figuras tão diversas? Mesmo assumindo a diversidade entre as mulheres e a perspectiva de colocar em debate o essencialismo que as aprisiona, o que tem servido de "liga" para a articulação do movimento?

Quem nos responde é o próprio MMC: "Pertencemos à classe trabalhadora, lutamos pela causa feminista e pela transformação da sociedade." 47

De fato, o que articula as mulheres do MMC é a questão do trabalho a partir da categoria "camponês" e "mulher camponesa, em uma perspectiva feminista", e é essa identidade que será significativa para definir o que é violência:

Fizemos debates sobre a categoria camponês que compreende a unidade produtiva camponesa centrada no núcleo familiar a qual, por um lado se dedica a uma produção agrícola e artesanal autônoma com o objetivo de satisfazer as necessidades familiares de subsistência e por outro, comercializa parte de sua produção para garantir recursos necessários à compra de produtos e serviços que não produz.

Neste sentido, mulher camponesa, é aquela que, de uma ou de outra maneira, produz o alimento e garante a subsistência da família. É a pequena agricultora, a pescadora artesanal, a quebradeira de coco, as extrativistas, arrendatárias, meeiras, ribeirinhas, posseiras, bóias-frias, diaristas, parceiras, sem terra, acampadas e assentadas, assalariadas rurais e indígenas. A soma e a unific ação destas experiências camponesas e a participação política da mulher, legitima e confirma no Brasil, o nome de Movimento de Mulheres Camponesas ${ }^{48}$.

O MMC toca, portanto, em uma categoria tradicional do pensamento que toma um grau de repercussão diferenciado a partir de Marx: o trabalho. Mas, tal como as elaborações de feministas marxistas, não fala do trabalho a partir de uma perspectiva tradicional, mas foca

\footnotetext{
47 “Quem somos”, escrito pelo próprio Movimento de Mulheres Camponesas em seu sítio na internet. Disponível em: <http://www.mmcbrasil.co m.br/site/node/43>. Acesso em: 5 set. 2014.

48 "História", escrito pelo próprio Movimento de Mulheres Camponesas em seu sítio na internet. Disponível em: <http://www.mmcbrasil.com.br/site/node/44>. Acesso em: 5 set. 2014.
} 
principalmente naquele trabalho das mulheres camponesas que era tido como "não trabalho": um trabalho realizado dentro de casa, nas suas cercanias no cuidado de pequenos animais ou, em boa parte das vezes, nas piores terras, visando à produção de alimentos para o consumo familiar.

As questões referentes ao mundo do trabalho, pois, e algumas categorias do materialismo e mesmo reutilizações da categoria do marxismo mostram-se essenciais como instrumentos de teorização e de compreensão da realidade do movimento. É o que faremos em seguida.

\subsection{Sexagem e as mulheres enquanto classe: a apropriação como categoria para releitura da divisão do trabalho}

Seguindo a linha do materialismo francófono, do qual já comentamos quando tratamos de Nicole-Claude Mathieu, encontramos Colette Guillaumin, que pensa nas mulheres como integrantes de uma classe, a partir das relações de trabalho que desenvolvem, e que são exploradas pelos homens, também enquanto classe.

Guillaumin, nas suas formulações teóricas, pensa nas categorias "trabalho" e "classe" de uma forma muito peculiar, a partir de mais duas categorias: a "apropriação" e a "sexagem", fazendo uma verdadeira revisão da visão clássica marxista a esse respeito.

O texto escolhido por nós é "Práctica del poder e idea de Naturaleza", publicado pela primeira vez em 1978, em língua francesa, e na revista Questions Féministes, n. 2 e 3, em 1989. Para esta pesquisa, estamos utilizando a versão em castelhano, publicada em 2005. Guilla umin usa conceitos do marxismo, mas os ressignifica.

Cabe-nos fazer uma ressalva antes de iniciar a discussão. $O$ texto traz uma série de exemplos e comportamentos sociais em parte já questionados e superados em relação a alguns grupos de mulheres no contexto em que foram escritos, a saber, uma sociedade francesa e urbana da década de 1970, e deve ser lido enquanto texto situado em seu tempo.

Por outro lado, a realidade ainda se mantém em alguns contextos dentro e fora da Europa, dada a diversidade de mulheres e implicações decorrentes de sua classe, raça-etnia, 
nacionalidade, geração, considerando também que elas não estão isoladas, mas em constante diálogo/conflito no espaço ${ }^{49}$.

No caso do presente trabalho, adensaremos as questões colocadas pela autora trazendo exemplos situados na história das mulheres urbanas e rurais no contexto brasileiro e destacando o quanto deles ainda se mantém.

De fato, não é difícil perceber, a partir das falas das camponesas, jurisprudências, pesquisas mais atuais, pautas dos movimentos de mulheres, como parte desses exemplos ainda se aplicam em um contexto do campo, e até mesmo da cidade, no Brasil. De modo especial, o campo, por ser ainda marcado por um forte patriarcalismo e conservadorismo e que mantém mulheres em uma posição de subalternidade mais agravada por razões entrelaçadas entre cultura e condição econômica.

A nosso ver, como o discorreremos a seguir, essa visão nos serve para a análise sobre a posição das mulheres no campo e as críticas realizadas a partir do Movimento de Mulheres Camponesas.

\subsubsection{Mulher enquanto classe?}

Guillaumin traz a originalidade de entender homens e mulheres como classes, construídas socialmente, inclusive no seu aspecto biológico, a partir de relações de "sexagem"; portanto, os homens e as mulheres entendidos de uma forma não essencialista.

As mulheres, no seu todo, seriam exploradas pela classe dos homens e a estes deveriam uma série de "serviços", aos quais se pode ou não atribuir valor monetário, o que ocorre de forma semelhante também com as raças/etnias e outras categorias a depender do contexto histórico e social.

\footnotetext{
49 A França (Paris, em especial), por exemplo, é um país que não comporta somente a mulher francesa e uma cultura urbana e ocidental, mas também mulheres árabes e africanas que se refugiaram no país que colonizou parte dos seus continentes e os saqueou, construindo assim sua própria civilização. Essas mulheres têm enfrentado grandes desafios para viver sua cultura nesse espaço, por essa cultura ser acusada de machista e contrária às liberdades fundamentais. De importante nota, foi a proibição que o governo francês impôs acerca do uso do véu nas escolas. A solução encontrada ia de encontro com a cultura daquelas mulheres (ou de suas famílias) acerca do uso obrigatório do véu.
} 
As mulheres, nesse ínterim, seriam exploradas a partir da sua identificação como pertencente a um sexo biológico que as ligaria mais à natureza e, mesmo pertencendo a classes sociais diversas, estariam em situação de exploração diante dos homens. A sua posição social, econômica e política seria sempre marcada anteriormente pelo fato de serem mulheres e as colocariam em posição de subalternidade em relação aos homens de sua familia e aos homens de modo geral.

Materialmente, as mulheres estariam submetidas em seu todo, em uma forma de trabalho específica e pré-moderna, semelhantemente ao que acontecia com os trabalhadores escravos das plantações e em outras relações entre classes, como a vassalhagem: esta forma de trabalho é a apropriação.

(...) en lo que respecta a la fuerza de trabajo en las clases de sexo. Una clase entera, que abarca aproximadamente a la mitad de la población, soporta no solamente el acaparamiento de la fuerza de trabajo sino una relación de apropiación física directa: las mujeres. Este tipo de relación no es desde luego exclusivo a las relaciones de sexos; en la historia reciente, caracterizaba a la esclavitud de plantación que no desapareció del mundo industrial sino hasta hace apenas un siglo (Estados Unidos 1865, Brasil 1890), lo que no significa que la esclavitud desapareció totalmente. Otra forma de apropiación física, el vasallaje, característica de la propiedad latifundista feudal, desaparecióal final del siglo XVIII en Francia (últimos siervos libertos hacia 1770, abolición del vasallaje en 1789), pero persistió más de un siglo aún en ciertos países de Europa. La relación de apropiación física directa no es por lo tanto una forma que sería propia a las relaciones de sexo (...) (GUILLAUMIN, 2005, p. 24).

Mesmo após o estabelecimento do modo de produção capitalista e as revoluções burguesas com a invenção do "trabalho livre", a posição das mulheres no mundo do trabalho vai além do que eventualmente (ou de forma cada vez mais frequente) possam realizar a partir da venda "livre" de sua força de trabalho em atividades várias que tomam o seu corpo e o seu tempo por inteiro.

Elas não se pertencem, pertencem sempre a outrem, como pais, irmãos, maridos e fil hos, estão "a serviço de" e isso traz repercussões sobre sua vida mesmo quando têm condição econômica superior e podem contratar outras mulheres para fazer serviços em seu lugar.

Todas essas obrigações traduzem que a mulher responde, em última instância, com seu corpo nas relações sociais das quais participa dentro da família que, mesmo não compreendidas como trabalho tradicional, implicam tarefas em que ela será apropriada em seu todo e, mesmo 
quando em execução de atividades em "pé de igualdade" com os homens, a elas sempre será exigido o corpo dentro de um padrão físico ${ }^{50}$ e se adequando a comportamentos ditados para o seu sexo.

Implica, por outro lado, que várias das decisões acerca de seu próprio corpo não thes pertence e as intervenções sobre ele serão inúmeras e contra a sua vontade, em nome da "sociedade".

No que diz respeito às mulheres enquanto sexo, há ainda outro instrumento que as obriga de forma especial em relação aos homens: o matrimônio ou o relacionamento afetivo de forma mais geral, desde namoros/noivados até relacionamentos estáveis com coabitação, não necessariamente legalizados pelo casamento ${ }^{51}$.

Se o trabalhador comum (homens e mulheres) comprometem-se por um contrato em que estabelecem forma de venda-compra de trabalho mediante remuneração, as mulheres, a partir do relacionamento afetivo, estabelecem forma peculiar de "contrato" que configura a apropriação:

En el acto que codifica el vínculo del matrimonio, no hay tampoco la enunciación jurídica de la propiedad de sí mismo. Como en el contrato de venta de la fuerza de trabajo, en que la significación oculta es la propiedad de sí mismo, en el "contrato" matrimonial la significación oculta es la no propiedad de sí mismo, expresada en una relación determinada: las mujeres no ceden su fuerza de trabajo; en efecto, como se observó, no intervienen aquí

\footnotetext{
50 Jornalista é criticada após aparecer de biquíni na praia e não corresponder(?) a um padrão de beleza esperado. Após várias manifestações acusando o sexismo da "reportagem", a mesma é retirada do ar e são solicitadas desculpas à jornalista. Disponível em: <http://www.brasil247.com/pt/247/midiatech/167381/R7 -pisa-na-bola-e mpatrulha-a-corpode-Fernanda-Gentil-que-está-grávida.htm>. Acesso: 20 mar. 2015.

51 A autora refere-se com exclusividade quanto ao matrimônio. Observamos, no entanto, como toda sorte de relações afetivas mais estáveis, como os namoros, exigem que a "namorada" tenha um padrão de comportamento e dela é exigido com muito mais força a monogamia, porque seu corpo é do seu namorado, não seu, e do seu próprio corpo não pode dispor, mesmo quando não está com esse namorado. Não são poucos também os homicídios praticados por rapazes quando se deparam com um final de namoro e a moça já esteja se envolvendo com outras pessoas, ou mes mo quando existe a suspeita de que ela esteja se relacionando com outras pessoas além dele durante o namoro. Algumas notícias mais recentes sobre o assunto, de forma não exaustiva: <http://g1.globo.com/espirito-santo/noticia/2014/06/odio-tomou-conta-de-mim-d iz-rapaz-que-filmou-ematounamorada.html>; <http://www.correio24horas.com.br/detalhe/noticia/estudante-matou-jovem-apos-fimdonamoro-de-infancia-ele-morreu-ao-bater-carro-e m-fuga/?cHash=dcd36fa4ce 1f6d157cb 59def3910d2f4>; $<$ http://www.youtube.com/watch?v=Ac_SPhUiFdM>;

$<$ http://www.paranaonline.com.br/editoria/policia/news/830713/noticia=RAPAZ+ATIRA+CONTRA+A +NAMO $\mathrm{RADA}+\mathrm{EM}+\mathrm{SHOPPING}+\mathrm{E}+\mathrm{TENTA}+\mathrm{SE}+\mathrm{MATAR}>$; $\quad<\mathrm{http} / / /$ www.fmintegracao.com.br/policia/5778 empres ario-joao-matias-mata-a-t iros-a-e x-na morada-e-atualna morado-em-u ma-fes ta-na-zona-rural-debotucatu>. Acessos em: 26 jan. 2015.
} 
ni medida de tiempo, ni acuerdo sobre la remuneración. Solamente la garantía de ser mantenida en estado de funcionamiento según los medios del propietario (en vida, "bien mantenida" como una máquina es bien conservada o no...) es dada como contrapartida de la cesión. Cesión de qué, a propósito? ¿Qué significa una cesión que atribuye todo el tiempo y todo el espacio corporal al comprador? El hecho de que no haya término al trabajo, ni medida de tiempo, ni noción de violación sexual (esto es de primera importancia), muestra que esta cesión es realizada en bloque y sin límites. Y que, por consecuencia, lo que es cedido no es la fuerza de trabajo sino efectivamente la unidad material que forma al individuo mismo (GUILLAUMIN, 2005, p. 46).

A autora considera que as tarefas relacionadas ao cuidado das crianças, dos enfermos e das pessoas com deficiência e as relacionadas ao ambiente doméstico, bem como a reprodução e o sexo, são uma forma especial de trabalho que corresponde às mulheres, mas que, diversamente aos outros tipos de trabaho, implicam domínio do próprio corpo das "trabalhadoras" e que, repisemos, as submetem no todo.

(...) En las relaciones de sexaje, las expresiones particulares de dicha relación de apropiación (la del conjunto del grupo de las mujeres, la del cuerpo material individual de cada mujer) son: a) la apropiación del tiempo; b) la apropiación de los productos del cuerpo; c) la obligación sexual; d) la carga física de los miembros inválidos del grupo (inválidos por la edad - bebés, niños, ancianos - o enfermos y minusválidos) así como los miembros válidos de sexo masculino (GUILLAUMIN, 2005, p. 26).

Guillaumin, como visto acima, dá a essa forma característica de trabalho o nome de "apropriação" e explica que se coloca às mulheres uma série de responsabilidades em relação à "classe" dos homens como um todo, mas, de um modo particular, aos homens de sua família (como pais, avós, irmãos, cunhados, tios etc.) e, de um modo mais particular ainda, ao homem com quem contrair matrimônio, incluindo aí as "tarefas" sexuais.

Em relação ao tempo, há que se ver que não há, tal como nas outras formas de trabalho, um limite para seu uso. Não há um dia estabelecido para o descanso. As mulheres podem ser requisitadas a qualquer hora do dia ou da noite, sete dias por semana, para executar tarefas de cuidado a outras pessoas e cumprimento de obrigações sexuais. 
No que diz respeito às obrigações sexuais, o tema ainda é tabu ${ }^{52}$, mesmo na atualidade, e mulheres se veem compelidas a fazer sexo (ou a praticar determinados atos sexuais, como, por exemplo, sexo anal, oral ou sexo sem preservativo, dentre outras possibilidades) com seus companheiros que fazem uso de força ou chantagem para obter o que desejam, mesmo contra o desejo da companheira.

O tema é silenciado a partir do receio de expor a si própria ou o seu relacionamento à chacota ou ao julgamento, quando deseja permanecer com o companheiro agressor, por vergonha de ter sua vida exposta (mesmo quando não está mais com o companheiro), ou até receio em relação à sua vida e integridade física (ou a de seus filhos e parentes) a partir de ameaças realizadas pelo ex-companheiro. É importante lembrar que o estupro dentro do relacionamento pode ou não vir acompanhado de outras violências praticadas contra a mulher.

No que diz respeito às mulheres camponesas, e outras mulheres mais ligadas à tradição (por motivos religiosos, por exemplo) mesmo nos espaços urbanos, há ainda a crença de que o sexo faz parte da "dívida conjugal" e é obrigação da mulher estar disponível quando o companheiro deseja fazer sexo. Faz parte dessa mesma tradição, conferir à mulher uma posição passiva de modo geral em relação ao homem e de forma ainda mais sensível quando se trata de sexualidade.

Isso implica que as mulheres, enquanto classe, terão um trabalho duplo ou triplo para conquista da própria autonomia, porque estarão, antes, sempre ocupadas de outras individualidades que não elas mesmas, de uma forma que a consumirá não só em tempo, mas em energia.

La individualidad, justamente, es una frágil conquista, a menudo rehusada a una clase entera a la que se le exige diluirse, material y concretamente, en otras individualidades.

Coacción central en las relaciones de clases de sexo, la privación de individualidad es la secuela o la cara oculta de la apropiación material de la individualidad. Porque no es tan obvio que los seres humanos se distinguen tan fácilmente los unos de los otros, y una proximidad/carga física constante es un poderoso freno a la independencia, a la autonomía; es la fuente de una imposibilidad de discernir, y a fortiori de poner en práctica, opciones y prácticas propias (GUILLAUMIN, 2005, p. 38).

\footnotetext{
52 Mulheres estupradas por parceiro costumam não denunciare carregam as sequelas psicológicas do sexo fo rçado, segundo reportagem publicada pelo jornal Correio Braziliense, em 11 de setembro de 2013. Acesso em: 4 dez. 2014.
} 
Isso porque o cuidado material físico que é colocado ao encargo das mulheres, quer dizer uma presença constante.

(...) una presencia constante. Nada de marcar tarjeta en este contexto, hablamos de una vida en la que todo el tiempo es absorbido, devorado en el cara a cara com los bebés, los niños, el marido; y también las personas de edad, los enfermos. Cara a cara porque sus gestos, sus acciones mantienen a la madre-esposa-hija-cuñada bajo su esfera de influencia. Cada uno de los gestos de estos individuos está lleno de sentido para ella y modifica su propia vida a cada instante: una necesidad, una caída, una solicitud, una acrobacia, una partida, un sufrimiento, la obligan a cambiar de actividad, a intervenir, a preocuparse por lo que hay que hacer inmediatamente, en unos minutos, a tal hora, esta noche, antes de tal hora, antes de partir, antes que $\mathrm{X}$ venga (...)

Cada segundo de su tiempo - y sin esperanza de ver cesar a hora fija esta preocupación, incluso en la noche -, ella es absorbida por otras individualidades, apartada por otras actividades de la que estaba realizando en el momento.

La coacción no reside solamente en la constancia de esta presencia y de esta atención, sino en el cuidado material físico del cuerpo mismo. Lavar los muertos es tarea del grupo de las mujeres, y esto no es insignificante. Como también lavar a los enfermos graves.

Además, la sujeción material a individualidades físicas es también una realidad mental. No hay abstracción: todo gesto concreto tiene una cara significante, una realidad "sicológica". Aunque se intente incansablemente constreñirnos a no pensar, esta sujeción no se vive mecánicamente ni en la indiferencia (GUILLAUMIN, 2005, p. 36-38).

Os produtos de seu corpo também não são seus, a saber, os seus filhos. Houve leis que deixavam bem claro que as mulheres, bem como os filhos, pertenciam aos homens/pais ${ }^{53}$, embora não coubesse a eles a responsabilidade acerca do cuidado.

Ainda hoje, em sociedades como a brasileira, na qual a legislação tomou rumos menos machistas, como retomaremos a seguir, não cabe ainda as às mulheres a decisão de ter ou não

\footnotetext{
${ }^{53}$ Nas primeiras ordenações do Brasil, havia mesmo a previsão de poder de vida e de morte sobre mulher e filhos. O "avanço" viria em 1912, com a edição do primeiro Código Civil Brasileiro, mas o art. 316 do referido código ainda previa que o poder sobre os filhos seria exercido pelo pai. Tal artigo permaneceu em vigor até 1962, quando, a partir das alterações propostas pelo Estatuto da Mulher Casada, Lei n. 4212, de 27 de agosto de 1962, o poder passou a ser exercido pelos pais, mas com a preponderância para o pai, quando houvesse divergência que somente poderia ser solucionada em juízo. Digno de nota é que até o Es tatuto da Mulher Cas ada previa que a mulher perdia o poder sobre os filhos de um primeiro casamento quando se separas se e contraís se novas núpcias (antes o art. 393 do CC de 1916 dispunha que haveria a perda). Somente com a Constituição de 1988 um padrão de igualdade formal entre homens e mulheres foi estabelecido. Dentre outras questões, a nomenclatura "pátrio poder" foi substituída por "poder familiar". Ordenações Filipinas disponíveis em: <http://www1.ci.uc.pt/ihti/proj/filipinas/ordenacoes.htm>. Acesso em: 11 abr. 2014.
} 
um filho, visto que the é vedada a prática do aborto (embora, na prática, há várias que o façam porque o homem não quer o filho e/ou ela mesma não o queira).

Também, os filhos continuam pertencendo ao pai, mesmo em caso de separação, sem implicar que eles tenham obrigações sociais ou jurídicas ${ }^{54}$ relativas ao cuidado, eles continuam tendo pleno direito sobre os filhos.

Destaque-se ainda que quando em guarda e vigilância dos pais, o que se tem em relação às crianças, no ordinário, é que não ele, mas outra mulher assumirá as tarefas de cuidado:

Los hijos siguen siendo en cambio un poderoso instrumento de chantaje en caso de desacuerdo conyugal: es su posesión lo que reivindican los hombres, y no su carga material, que ellos se apresuran en confiar a otra mujer (madre, doméstica, esposa o compañera) según la regla que estipula que las posesiones de los dominantes sean cuidados materialmente por una (o unas) posesión de los mismos. La posesión de los hijos, "producción" de las mujeres, les corresponde aún jurídicamente a los hombres en última instancia; los hijos continúan perteneciendo al padre, incluso cuando la madre tiene la carga material de éstos em caso de separación (GUILLAUMIN, 2005, p. 28).

\footnotetext{
${ }^{54}$ A eles coube, por exemplo, no direito civil brasileiro, até dezembro de 2014, o "dever" de fiscalizar o cuidado que a outra parte (no caso a mãe) dá à criança, embora o mesmo não seja obrigado a cuidar da criança.

Art. 1.583. A guarda será unilateral ou compartilhada.

(...)

$\S 5^{\circ}$ A guarda unilateral obriga o pai ou a mãe que não a detenha a supervisionaros interesses dos filhos, e, para possibilitar tal supervisão, qualquer dos genitores sempre será parte legítima para solicitar informações e/ou prestação de contas, objetivas ou subjetivas, em assuntos ou situações que direta ou indiretamente afetem a saúde física e psicológica e a educação de seus filhos.
}

Em tese, na verdade, não há qualquer menção jurídica de deveres das mulheres em relação ao cuidado das crianças. Por outro lado, há uma pressão social intens a e uma atribuição desigual de respons abilidades emcaso de abandono, mes mo pelo judiciário, na verificação de questões concretas. O resultado era atribuir o peso da responsabilidade às mulheres, mas oportunizar aos homens que exercessem, quando quisessem, a gestão, a decisão e o controle. "Prestar contas", por muitas vezes, queria dizer compartilhar, com o outro de quem se separou e que não tem o peso do cuidado, sua vida diária, adaptada para possibilitar es se cuidado. Aúnica obrigação que poderia ser exigid a juridicamente dos homens era tão somente a financeira, que não leva em consideração, na sua conta, o trabalho que as mulheres dedicam durante as noites, madrugadas e finais de semana para guarda e vigilância das crianças (is so quando se compreende para estipulação da pensão, o pagamento de uma outra mulher para execução de trabalhos domésticos - com remuneração menor do que outros trabalhadores em horário comercial ou do pagamento de escolas que cumprem, em parte, a tarefa de guarda e vigilância das crianças durante parte ou de todo o dia). No mesmo sentido, de garantia de direitos aos homens sem o estabelecimento necessário de obrigaçõ es, configurou-se a reforma estabelecida pela Lei n. 13.058, de 22 de dezembro de 2014, que previu a obrigatoriedade de guarda compartilhada em caso de disputa pelo ex-casal, mas que continua prevendo que se pode abdicar da guarda. Diante das relações de poder colocadas atualmente, a lei estabelece direitos para os homens, mas continua não prevendo qualquer medida em relação ao pai que não se implica nas relações de cuidado. Acerca do assunto, vide postagens do blog "Femmaterna" sobre o assunto, em especial, a postagem "Porque o papai foi embora", dis ponível em: <http://femmaterna.com.br/por-que-o-papai-foi-embora/>. Acesso em: 26 mar. 2015. 
Por fim, mas não menos importante, segundo Guillaumin, cabe à mulher a obrigação sexual. Obrigação, ou dever, porque ainda não é vista como sujeito que pode e quer sentir prazer, como ser autônomo que quer viver sua sexualidade; mas é vista ainda como objeto que será possuído por um homem (no caso de um relacionamento fixo com um deles) ou que estará à disposição de forma indiscriminada a todos eles. Em ambos os casos, a mulher pode ser sujeita a sexo forçado, quer pelo seu marido/companheiro/namorado, quer por amigos dela, conhecidos ou até desconhecidos.

Entenda-se que o interdito aos homens para a não realização de ato sexual com uma mulher não é a vontade de uma mulher, mas o respeito a outro homem que a possua. Essa possessão deve ser demonstrada mesmo quando o seu possuidor não se encontra presente, porque é materializada em toda uma ordem de conduta que a mulher deva seguir. Conduta essa ditada socialmente, mas ainda dirigida pelo homem com quem ela se relaciona, o que indica que ele (ou a sociedade, em nome dele) vai dizer as roupas que ela deve vestir, com quem ela deve falar, as atividades e horários com que ela deve se envolver.

\subsubsection{Meios utilizados para manter as mulheres, enquanto classe, em situação de apropriação pelos homens}

E por que as mulheres se submetem, segundo a autora? Quais são os meios utilizados para manter as mulheres, enquanto classe, em situação de apropriação pelos homens?

Segundo Guillaumin, estes meios podem ser reunidos em cinco: o mercado de trabalho, o confinamento no lar, a imposição de violência, a obrigação sexual e o arsenal jurídico e o direito consuetudinário (2005, p. 46 e ss).

No que diz respeito ao mercado de trabalho, cabe mencionar que os trabalhos destinados às mulheres são os piores remunerados ou os que atingem maior flexibilidade quanto ao respeito de direitos conquistados por outras classes de trabalhadores e, quando ocupam os mesmos postos que os homens, recebem remuneração 2/3 menor que eles, sem contar que dificilmente conseguem ascender a cargos de diretoria, que são melhor remunerados.

E em nível de Brasil, nos dias de hoje, a teoria da autora nos ajuda a compreender a situação? Vejamos o que nos informa a própria Secretaria de Políticas para as Mulheres da Presidência da República: 
Na população economicamente ativa (PEA), $42 \%$ das pessoas ocupadas são mulheres. Ainda que a taxa de desemprego das mulheres tenha caído de 15,2\% para 7,5\% entre 2003 e 2011, as mulheres ainda encontram piores condições de trabalho: salários mais baixos; acúmulo de tarefas devido à dupla jornada de trabalho; e sofrem sistematicamente com a discriminação e a violência nas suas relações de trabalho.

(...)

As desigualdades podem ser percebidas também com relação à remuneração. Mesmo sendo mais escolarizadas, as mulheres ganham menos. Dados da Pesquisa Nacional por Amostra de Domicílios - PNAD de 2012 indicam que a redução desse déficit, que historicamente vinha caindo, sofreu um ligeiro retrocesso, passando as mulheres a receber em média, $72,9 \%$ dos rendimentos do trabalho dos homens. Essa relação era de 73,7\% em 2011.

Entre os principais desafios para o Brasil no campo da autonomia econômica e igualdade na esfera do trabalho, destacam-se: reduzir a diferença salarial existente entre mulheres e homens; ampliar as políticas públicas e o acesso a bens e serviços que incidem sobre o cotidiano e os cuidados; e estabelecer responsabilidade compartilhada sobre os cuidados reprodutivos, incluídos o cuidado com os filhos, com o lar, com idosos e enfermos, entre outros, revendo a dupla jornada de trabalho que sobrecarrega as mulheres..$^{55}$

Como se sustentar e aos seus filhos sem se unir a um homem? Tais fatos acabam colocando o casamento como um caminho para uma melhora virtual das condições de vida para boa parte das mulheres: 'Las mujeres son así intimadas a encontrar un empleo de esposa (de mujer), es decir de venderse y no de vender su sola fuerza de trabajo, para poder vivir y hacer vivir a sus hijos" (GUILLAUMIN, 2005, p. 47).

Importante lembrar que essa ideia foi forjada desde o Brasil Colônia, com um grande apoio da Igreja Católica, que queria moralizar as relações na "nova terra". A partir do matrimônio, a mulher não se veria mais sozinha (?) com os encargos decorrentes dos filhos que nasciam mestiços ou não.

O segundo meio é o confinamento no lar, ideia poderosa erigida a partir de um adestramento que tem um caráter positivo e um negativo.

A partir de uma perspectiva positiva, faz-se com que a mulher acredite na sua imprescindibilidade em relação ao lar, "la interiorización de la cerca", utilizando-se a poderosa

\footnotetext{
55 Informe Nacional BRASIL, Consenso de Brasília. XI Conferência Regional sobre a Mulher da América Latina e Caribe. Brasília, outubro de 2013. SPM/PR. Disponível em: <http://www.cepal.org/12conferenciamujer/noticias/paginas/7/49917/Informe_Brasil__Consenso_de_Brasilia.pdf>. Acesso em: 3 nov. 2014.
} 
ideia de que não há pessoa mais capaz para cuidar do lar, dos filhos e do homem que a mulher. Sem ela, tudo se desmorona. Não há ninguém que possa substituí-la.

$\mathrm{Na}$ sua vertente negativa, o caráter limitador do adestramento é mais claro. A "confinação ao lar" atende a padrões de moralidade e há mesmo uma condicionante para a fruição do direito de ir e vir: a permissão masculina. As mulheres que têm um relacioname nto, mesmo quando não coabitam, devem obter permissão quanto a saídas, quer seja para trabalho ou lazer.

La interiorización de la cerca se obtiene a través de un adiestramiento positivo y también de un adiestramiento negativo. En el primer caso: "Tu lugar está aquí, eres la reina del hogar, la maga en la cama, la madre irremplazable. Tus hijos se volverón autistas, de carácter difícil, idiotas, delincuentes, homosexuales, frustrados, si no te quedas en la casa, si no estás aquí cuando llegan, si no les das el seno hasta los tres meses, seis meses, tres años, etc., etc.”. En resumen, no hay nadie más que tú para hacer todo esto, eres irremplazable (sobre todo por un macho). En el segundo caso: "Si sales, mis congéneres te acosarán hasta que renuncies, te amenazarán, te harán de mil maneras la vida imposible, agotadora. Tienes permiso (es una orden) de ir a la tienda de abarrotes, a la escuela, al mercado, a la alcaldía y a la calle principal donde estan los almacenes. Y puedes ir entre las siete de la mañana y las siete de la noche." (GUILLAUMIN, 2005, p. 48)

Limita-se, pois, como já comentamos, a permanência da mulher fora do lar ao estritamente necessário, devendo ela obter a permissão ao marido (ou até namorado) ${ }^{56}$ caso tenha alguma oportunidade ou necessidade de executar qualquer tarefa, diversão ou trabalho, em especial no horário noturno.

O confinamento no lar ou qualquer outra regra de conduta é mantida pela imposição da violência socialmente legitimada.

Caso a mulher não se comporte nesse padrão acima e desrespeite o marido ou as normas impostas em seu nome ${ }^{57}$, entende-se que é possível cercear à força o direito de ir e vir da mulher,

\footnotetext{
${ }^{56}$ Em levantamento promovido pelo Instituto Avon e Data Popular, publicado em vários veículos de comunicação, em dezembro de 2014, foi destacado que $48 \%$ dos jovens acham errado mulher sair sem namorado, dentre outras formas de controle. Foram consultadas 2.046 pessoas, entre 16 e 24 anos, das cinco regiões do país. Disponível em: <http://g1.globo.com/bemestar/noticia/2014/12/48-dos-jovens-acham-errado-mu lher-s air-sem-o-na moradodizpesquisa.html5>. Acesso em: 14 jan. 2015.

57 Saffioti traz interessante observação em artigo publicado no livro "Marcadas a Ferro" (2005), sobre a desnecessidade da presença física do "patriarca" para a imposição de normas sobre a mulher, a partir da análise da obra cinematográfica "Lanternas Vermelhas": "O filme Lanternas Vermelhas, dirigido por Zhang Yimou, apresenta
} 
mantendo-a em verdadeiro cárcere privado, e/ou mesma submetê-la a partir da força física com a imposição de surras ou de sofrimento psicológico decorrente de menosprezo, xingame ntos ou ameaças.

A demonstração de força física ou de sofrimento psicológico, em verdade, é usada não só contra as mulheres da família, senão contra todas as mulheres, desde que se mostrem desviadas de sua posição sexual-social. É importante reforçar que a violência (física, sexual, psicológica) é integrante das relações sociais entre homens e mulheres em uma sociedade patriarcal.

Primero, no es excepcional cuantitativamente, y sobre todo, es socialmente significativa de una relación social: constituye una sanción socializada del derecho que se arrogan los hombres sobre las mujeres, tal hombre sobre tal mujer, e igualmente sobre todas las demás mujeres que "se desvían". Esto está vinculado con el confinamiento en el espacio y a la coacción sexual (GUILLAUMIN, 2005, p. 49).

A imposição da violência contra a mulher não é, pois, fato isolado, situação excepcional e fora da normalidade que acomete homens "doentes", mas é prática disseminada e segue uma sistemática, legitimada socialmente a partir de uma série de ações e omissões: é aquele julgamento acerca dos motivos para a surra que uma mulher tenha levado ou mesmo seu assassinato, de forma a minorar a responsabilidade do homem que a agrediu/assassinou; é o siêncio da vizinhança e dos amigos próximos diante de uma situação de violência física ou psicológica; é a negativa de acolhida a uma mulher porque é a segunda ou terceira vez que ela tenta sair do ciclo de violência; é encarar a violência contra a mulher como uma questão menor dentre as outras lutas; é garantir poucos recursos para políticas voltadas à assistência e

imagens e trama reveladoras do acima expresso. Além de o patriarcado fomentar a guerra entre as mulheres, funciona como uma engrenagem quase automática, pois pode ser acionada por qualquer um, inclusive mulheres. Quando a quarta esposa, em estado etílico, denuncia a terceira, que estava com seu amante, à segunda, é esta que faz o flagrante e que toma as providências para que se cumpra a tradição: assassinato da 'traidora'. O patriarca nem sequer estava presente no palácio onde se desenvolveram os fatos. Durante toda a película, não se vê o rosto deste homem, revelando este fato que Zhang Yimou captou corretamente esta estrutura hierárquica, que confere aos homens o direito de dominar as mulheres, independentemente da figura humana singular investida de poder. Quer se trate de Pedro, João ou Zé Ninguém, a máquina funciona até mesmo acionada por mulheres. (...) Ainda que não sejam cúmplices deste regime, colaboram para alimentá-lo". Ver: SAFFIOTI, Heleieth. Gênero e Patriarcado: a necessidade da violência. In: CASTILLO-MARTÍN, Márcia; OLIVEIRA, Suely de (Orgs.). Marcadas a ferro. Brasília: Secretaria Especial de Políticas Para as Mulheres, 2005. p. 39. 
assessoria à mulher que sai de uma relação violenta ou mesmo priorizar programas para homens agressores.

Apesar de soar forte demais, seguindo o mesmo raciocínio, a coação sexual (ou constrangimento ilegal) e o estupro fazem parte das relações sociais entre homens e mulhe res porque todas elas têm um quantun de apropriação pelo todo ou pelo seu companheiro direto. Seu corpo não lhes pertence. Ou pertence a um homem (seu marido, namorado, companheiro) ou pertence a todos os demais:

Toda mujer no apropiada oficialmente a través del contrato que reserva su uso a un solo hombre, es decir toda mujer no casada o haciendo algo sola (circulando, consumiendo, etc.) es objeto de un concurso que revela la naturaleza colectiva de la apropiación de las mujeres. (...) Para afirmar mejor su derecho común de propiedad, los hombres ponen en juego entre sí las preeminencias de clase, de prestigio, tanto como la fuerza física. Esto no necesariamente toma una forma apocalíptica com morados y chichones, pero la competencia entre los individuos de la clase de sexo dominante para hacerse de (o recuperar, o aprovecharse de...) toda mujer "disponible", es decir, automáticamente toda mujer cuya individualidad material no está oficialmente u oficiosamente circunscrita, expresa que el conjunto de los hombres dispone de cada una de las mujeres, puesto que entre ellos es asunto de negociación o de lucha decidir quién se llevará la tajada, según una de las expresiones más exactas (GUILLAUMIN, 2005, p. 49).

O que é a dificuldade em caracterizar o estupro senão a realidade da apropriação?

Ora, há uma verdadeira complexificação para se identificar se tal ou qual relação sexual foi realizada contra a vontade da mulher porque a própria "vontade" da mulher é uma questão "relativizada" pela sociedade patriarcal. Relativizada porque, no fundo, não importa mesmo o que essa mulher queira diante da vontade de um homem de impor o seu desejo sexual sobre ela ou de, simplesmente, usar o estupro para colocá-la "em seu lugar".

A uma, porque, a partir da etiqueta sexual que lhe dita uma conduta de espera e de necessidade de recusa, ela não pode dizer que quer ou não quer sexo, ela só pode dar "sina is" tênues a esse respeito; de modo que um estupro pode ser tido tão somente como uma falha na interpretação desses "sinais".

A duas, porque a relação sexual não é vista como algo de que a mulher possa desfrutar, mas é tida como uma verdadeira "moeda de troca" que é utilizada como negociação para obter outras coisas como: "segurança" financeira e emocional por estar em um relacionamento, um 
objeto, como um presente, ou mesmo para obter um comportamento específico, como consertar uma coisa quebrada em casa. O que quer dizer que se o homem "paga" com "segurança" ou presentes e a mulher aceita, ele tem o direito ao produto, ou seja, a relação sexual.

Em outras palavras, os estupros, entendidos como sexo sem consentimento com ou sem grave ameaça, são corriqueiros simplesmente porque a vontade da mulher não interessa tanto. Ela não é dona de si própria, mas está ou à disposição de todos ou sob o domínio de alguém.

Retomamos o texto de Mathieu que dialoga com a nossa ideia a partir do ponto levantado por Guillaumin sobre a questão da violência sexual.

Referenciando-se com base em outras autoras do materialismo francófono e/ou outras autoras dentro ou na crítica ao marxismo, Mathieu coloca que a vontade sexual e a potência reprodutiva foram dissociadas nas mulheres, sendo-lhes negada a possibilidade de ser um sujeito que tem desejo, impondo-lhes uma regularidade do coito (a partir dos casamentos) e tornando a heterossexualidade como destino natural:

Una vez establecida esta <<domesticación〉> de la sexualidad de las mujeres (según la expresión de P. Tabet), se vuelve difícil considerar el sexo como un simple dato biológico <<natura $\gg$. Rubin (1975: 179) estimaba que $<<\ldots$ en el nivel más general, la organización social del sexo descansa en el género, la heterosexualidad obligatoria y la coacción sobre la sexualidad de las mujeres.> (MATHIEU, 1989, p. 159).

De fato, as mulheres do campo, quando reúnem coragem, mencionam que já sofreram estupro marital ou sofrem violência física pelo fato de se recusar a fazer sexo com os maridos/companheiros.

Dados de uma pesquisa feita pela Contag em 2008, durante a $4^{\mathrm{a}}$ Plenária Nacional de Mulheres Rurais, reunindo 529 mulheres de todo o País, revelou que $55,2 \%$ das entrevistadas haviam sofrido algum tipo violência. Destas, $21,9 \%$ foram vítimas de violência física, $51,1 \%$ sofreram violência moral, $27,3 \%$ sofreram violência sexual.

Do total das mulheres entrevistadas, $27,6 \%$ responderam que haviam sido ameaçadas de morte, $11,9 \%$ haviam sofrido estupro marital e $4,3 \%$ foram 
vítimas de cárcere. A pesquisa revelou ainda que $63,7 \%$ das violências domésticas foram praticadas pelos maridos ou companheiros das vítimas. ${ }^{58}$

A sexualidade, para as mulheres, reduzida ao caráter de reprodução da espécie (ou mesmo de escape para a virilidade masculina), pode ser visto como verdadeiro trabalho ${ }^{59}$ e como trabalho passa a ser problematizado, em crítica à (ou com base na) obra marxista:

Numerosas autoras feministas (cf. entre otras Edholm, Harris \& Young 1977 y Mies 1983) han criticado a Marx y a la tradición marxista por haber conservado un estatus de naturalidad a la división del trabajo entre los sexos, y han llamado a analizar las relaciones sociales de producción entre los sexos. Por su parte, Tabet (1985) demuestra que se puede considerar la reproducción como un trabajo, socialmente organizado, como cualquier trabajo, y analizar las relaciones sociales de reproducción entre los sexos bajo el mismo ángulo que el análisis marxiano [marxienne] del trabajo - y entre otros, em muchos casos, del trabajo explotado, en el que el trabajador (en este caso la mujer) puede ser expropiado(a) del control y de la gestión del instrumento de reproducción (su cuerpo), de las condiciones y de los ritmos del trabajo (por ejemplo, sucesión de embarazos), y de la cantidad y calidad (el sexo) del producto (el niño) (GUILLAUMIN, 2005, p. 159-160).

A coação sexual, ou ameaça constante de estupro, como forma de impor-lhe comportamentos, ou o estupro como punição, é também prática reiterada, embora não permitida em lei no Brasil.

A coação sexual está implicada em uma das formas de relações desiguais de poder e se reproduzem para outras relações sociais. É significativo que a palavra "foder", por exemplo, sirva para destacar o ato sexual em uma posição sujeito-objeto, uma pessoa "fode" e a outra é "fodida", e ao mesmo tempo sirva para destacar que alguém colocou-se acima de outrem, que foi dominada, subjugada, prejudicada.

\footnotetext{
58 "Mulheres do campo em situação de violência serão atendidas por unidades móveis", matéria disponível no Portal Brasil, publicada em 20 de setembro de 2012. Disponível em: <http://www.brasil.gov.br/cidadania-ejustica/2012/09/mulheres-do-campo-em-situacao-de-violencia-serao-atendidas-por-unidades-moveis >. Acesso em: 5 dez. 2014.

${ }^{59}$ Não é à toa que algumas mulheres ainda almejem casar-se com um homem de boa condição social, ou mesmo um homem que a sustente minimamente, em troca de "serviços" sexuais e domésticos, que estejam sendo pleiteados direitos previdenciários para as "donas de casa" e que a prostituição almeje alcançar o status de "trabalho", com respectivos direitos trabalhistas e previdenciários.
} 
La llamada agresión "sexual" es todo menos sexual; no es de hecho ninguna casualidad si la simbólica literaria de la sexualidad masculina es policiaca (confesiones, suplicio, carcelero, etc.), sádica, militar (plaza fuerte, sin miramientos, sitiar, vencer, etc.) y que recíprocamente las relaciones de fuerza tienen un vocabulario sexual (chingar, joder, etc.) (GUILLAUMIN, 2005, p. 55)

Acerca do arsenal jurídico e direito consuetudinário, como última forma listada pela autora de manutenção das mulheres em uma situação de apropriação, a autora elenca uma série de leis que restringiam os direitos das mulheres, a partir do matrimônio. Um "arsenal jurídico" que se colocava como mais um instrumento para colocar a mulher "em seu lugar": o de objeto (a ser) apropriado.

El arsenal jurídico fija las modalidades de apropiación privada de las mujeres, a no ser también las de la apropiación colectiva, la cual como vimos es no dicha y no contractualizada. En un cierto sentido, tal arsenal fija los límites de dicha apropiación, ya que no interviene sino en el matrimonio - forma restrictiva de apropiación colectiva de las mujeres (GUILLAUMIN, 2005, p. 50).

À primeira vista, as restrições são dirigidas apenas a uma relação privada, mas, na verdade, são mais amplas e alcançam a mulher nas suas relações políticas. Retiram-lhe a possibilidade mesma de que seja cidadã e a calam politicamente, porque fortalecem uma série de impedimentos para que as mulheres possam se defender no espaço público.

En un cierto sentido, tal arsenal fija los límites de dicha apropiación, ya que no interviene sino en el matrimonio - forma restrictiva de apropiación colectiva de las mujeres. Pero si la apropiación de las mujeres es manifiesta a través de las diversas disposiciones de la forma matrimonio (fuerza de trabajo, filiación y derecho sobre los hijos, domicilio, etc.), su inexistencia en tanto que sujeto rebasa ampliamente el marco de la legislación matrimonial. Si lo que está relacionado con la posesión de los bienes y su disposición, con los hijos y las decisiones de toda clase, es explícitamente masculino (lo que no está expresado abiertamente como tal, es efectivizado en los hechos), una noción más "general" tal como la ciudadanía, también es sexuada (GUILLAUMIN, 2005, p. 50-51). 
Esse relacionamento estreito entre os espaços públicos e privados já foi abordado quando falamos na forma de intervenção do MMC com as mulheres no debate sobre a violência, mas aproveitamos para repetir: é na chamada das mulheres para o espaço político (e público), para a discussão da pauta do trabalho, que as mulheres percebem com mais força os grilhões que as prendem ao lar e ao espaço privado e toda a sorte de violências decorrentes daí. Para ocuparem o espaço público acabam por ter que discutir suas relações privadas. Ou é isso ou não podem sequer sair de casa.

Uma pesquisa ${ }^{60}$ que versou sobre a história de vida de Luci Choinaski, primeira mulher declaradamente camponesa a ocupar uma vaga no parlamento brasileiro, recupera um pouco também dessa articulação e dificuldades na ocupação do espaço público:

Mas as mulheres, incluindo Luci, estavam vivendo intensamente o Movimento; eram dezenas de reuniões, discussões, grandes encontros que reuniam milhares de mulheres. Com a militância, outras questões privadas, pessoais, mas não menos políticas, iam surgindo também:

A nossa tarefa de trabalhadoras na roça, na casa, responsáveis pela comida e pela roupa lavada, não mudou nada. Mas com a necessidade da militância tínhamos que trabalhar bem mais. Por exemplo, a roupa ficava acumulada uma semana. Quando chegávamos, tínhamos que trabalhar bem mais para dar conta de lavá-la. O mesmo com a casa e outras coisas. (...) Iniciou-se um processo de conflitos, porque deixamos de ser as mulheres comportadinhas, que ficavam só em casa, fazendo de tudo, sem dizer não a nada. (...) Com isso, começou a se discutir o papel do homem e da mulher. Será que era só mulher que tinha que cuidar dos filhos, da casa, cozinhar? As questões de gênero começaram a ser discutidas, embora sem muita clareza, mas de forma bem prática, concreta. Muitos companheiros foram solidários. Outros não conseguiram aceitar esse processo, que foi bastante conflituoso (PAULILO; SILVA, 2010).

A pressão organizada das mulheres foi impulsionando gradativas mudanças em aspecto jurídico e boa parte das legislações elencadas pela autora não mais persistem na França e em outros países no mundo ocidental.

Não nos deteremos em pormenores sobre como esse processo se deu, mas voltaremos ao assunto no próximo capítulo, no que diz respeito às questões relacionadas com a

\footnotetext{
60 "Memórias de Luci Choinaski: histórias e lutas pelos direitos das mulheres camponesas", de Maria Ignez Paulilo e Cristiani Bereta da Silva. In: Gênero e geração em contextos rurais. Organizadores: Parry Scott, Rosineide Cordeiro e Marilda Menezes. Ilha de Santa Catarina: Ed. Mulheres, 2010.
} 
conformação/deformação/disputa que marcam as relações sociais e suas implicações no Direito brasileiro.

\section{2 "Patriarcado e Capitalis mo" ou "Sexo com Classe": uma leitura a partir da Divisão Sexual do Trabalho e a consubstancialidade das relações sociais}

Há ainda uma última necessidade de categorização para a compreensão do feminis mo camponês, de acordo com o posicionamento teórico adotado, com a realidade das camponesas que situam as análises, a forma de atuação do $\mathrm{MMC}$, bem como sua leitura sobre violência contra a mulher no contexto específico do campo.

De uma forma mais apurada (ou detalhada), uma outra francesa, Danièlle Kergoat, pertencente a mesma linha teórica das materialistas francófonas acima mencionadas, desenvolve bases importantes sobre a categoria já comentada da "divisão sexual do trabalho" e a implicação desta sobre a vida das mulheres para além de uma leitura clássica que enxerga a divisão sexual do trabalho de forma estática a partir das esferas de "produção" e "reprodução social" e desenvolvida a partir de competências inatas de homens e mulheres.

E mais: Kergoat estabelece uma teoria que permite explicar como se relacionam as categorias de classe, gênero e origem, e mesmo outras formas de opressão fundadas em questões de raça/etnia, dentre outras, que nos permitem analisar como é lido o relacionamento de patriarcado e capitalismo no campo, pelas lideranças do Movimento de Mulheres Camponesas, e que determina como elaboram sua leitura de feminismo baseado em uma identidade camponesa que ao mesmo tempo se reivindica, mas que se questiona no que diz respeito às relações de poder:

(...) aí a gente fala não só a violência física e psicológica, na questão machista e patriarcal, mas também como a questão machista e patriarcal se entrelaçam dentro do modelo de sociedade onde as mulheres são afetadas e muito afetadas (...) que é essa questão de que as mulheres são excluídas. Não tem acesso a crédito, não tem acesso a questão da autonomia econômica que é muito mais forte nas mulheres do campo que as mulheres urbanas que queira ou não queira as mulheres da cidade tem condição de ter um emprego e ela vai ter uma carteira assinada e ela vai receber aquele dinheiro por mais que talvez lá fora, depois, dentro da casa aquele dinheiro não fique na mão dela, mas ela teve um certo acesso. Mas as mulheres do campo não porque é diferente. Você não trabalha com um salário. Você trabalha com uma safra. Você planta, daí 
um recurso e quem tem o acesso direto é o marido. A mulher nem vê o dinheiro. Muitas vezes não define onde vai ser aplicado esse dinheiro. Essas questões são diferenciadas e é esse o feminismo que a gente faz. (informação verbal). ${ }^{61}$

(...) o que fragiliza muito as mulheres no campo primeiro é uma cultura muito reforçada pelo campesinato do chefe da família, da cultura camponesa, da religião muito forte. Coloca o homem como chefe, como provedor. A outra coisa é a questão da renda. A renda é uma coisa que pra mim no campoé mais grave das mulheres permanecerem em situação de violência. Por que? Vou pegar o exemplo de uma unidade familiar que produz banana. Então nesse bananal, na roça da família, trabalha todo mundo pra produzir. E no cuidado das coisas da galinha, do queijo, dos ovos, da cebolinha, dos chás... Isso é muito obrigação e tarefa das mulheres e crianças. Isso autosustenta a família. A mandioca, a galinha, o queijo, os chás, isso autosustenta a família, mas não gera renda monetária. O que vai pro mercado pra tornar dinheiro, pra comprar outras coisas de necessidade é do homem. Quem vai pro mercado vender a banana é o homem e normalmente ele compra o que é necessário pra família. Mas ele muito raro discute o que a família precisa. Então às vezes a família precisa de comprar um fardo de tecido, mas na cabeça dele tem que comprar uma bola de arame pra cercar o pasto. Então assim, pode ficar sem roupa. Mas a minha bola de arame, a minha vaca não. Porque isso é um valor monetário também pra essa cultura de dominação. Então eu acho que tem essas diferenças aí. ${ }^{62}$

Como pode ser observado nas falas acima selecionadas, a questão do ser camponesa, seus desafios próprios, bem como a violência que sofrem, passa por relações de poder que se desenvolvem de forma desigual entre homens e mulheres e que passa pelo trabalho. A compreensão sobre como o capitalismo age no campo é reivindicada pelo movimento para a própria compreensão dessa desigualdade que se daria de forma diversa a que enfrentam as mulheres no espaço urbano.

Para nós, e as autoras que selecionamos, as categorias do capitalismo (classe), e do feminismo (sexo ou gênero, se assim preferirem), podem ser lidas de forma congregada.

Vimos, quando expomos as análises de Scott no início deste trabalho, porém, que parte do feminismo acadêmico que se hegemonizou nos estudos "de gênero" afirma o contrário: que não é muito viável a leitura das duas categorias, quer porque tenham tradições diferenciadas,

\footnotetext{
${ }^{61}$ Entrevista concedida por Entrevistada “B” [ago. 2014]. Entrevistadora: Diana Melo Pereira. Brasília, 2014. arquivo .mp3 (52'36").

62 Entrevista concedida por Entrevistada "B” [ago. 2014]. Entrevistadora: Diana Melo Pereira. Brasília, 2014. arquivo .mp3 (52'36").
} 
quer porque houve uma supervalorização da categoria "classe" em detrimento da categoria "gênero". Como fazer essa leitura sem cair nas armadilhas já citadas neste trabalho?

O que nos cabe, desta forma, é pensar de que forma as categorias patriarcado e capitalismo se relacionam e atuam como condicionantes importantes na vida das mulheres no campo, visto que essas categorias têm sido tomadas de forma isolada pela academia, ora pelos marxistas, centrando-se no debate da opressão gerada a partir das relações de produção, ora pelas feministas, centrando-se no debate da opressão a partir das relações de gênero (ou de relações sociais de sexo, conforme preferimos) nos âmbitos da dita reprodução social.

Segundo Danièle Kergoat (2000):

Portanto, os grupos de sexo não sendo mais "categorias" imutáveis, fixas, ahistóricas e a-sociais, podemos periodizar a relação que os constitui um pelo outro (graças à análise da evolução das modalidades das questões sociais) e podemos então abordar o problema da mudança - e não somente do rearranjo - do social.

(...)

- É necessário centrar a refle xão somente sobre as relações sociais de sexo ou, ao contrário, tentar pensar o conjunto das relações sociais em sua simultaneidade? A tentação de hegemonizar uma só relação social - no caso a relação social de sexo - é grande, mesmo que fosse só para tentar preencher o vazio quase total na matéria.

Estes trabalhos, geralmente brilhantes (pensemos por exemplo nos de Delphy, Guillaumin, Mathieu...), oferecem instrumentos poderosos, novos e explicativos. Mas considerar somente a relação de dominação homem/mulher, e as lutas contra ela, é insuficiente para tornar inteligíve is a diversidade e a complexidade das práticas sociais masculinas e femininas. ${ }^{63}$

De forma diversa do caminho apresentado por parte do feminis mo acadêmico e mesmo do movimento feminista que isolou a categoria "classe" como importante para a análise sobre a dita opressão de gênero, portanto, Kergoat provoca quando afirma que as relações desiguais dão-se entre homens e mulheres para além de uma questão cultural, mas se assentam em uma base material, a partir da divisão sexual do trabalho, sendo inviável compreender uma sem a outra e enfrentar a superação das desigualdades sem compreender o papel da divisão sexual do trabalho:

${ }^{63}$ Sem grifo no original. 
(...) relações sociais de sexo e divisão sexual do trabalho são dois termos indissociáveis e que formam epistemologicamente um sistema; a divisão sexual do trabalho tem o status de enjeu das relações sociais de sexo.

Estas últimas são caracterizadas pelas seguintes dimensões:

- a relação entre os grupos assim definidos é antagônica;

- as diferenças constatadas entre as práticas dos homens e das mulheres são construções sociais e não provenientes de uma causalidade biológica;

- esta construção social tem uma base material e não é unicamente ideológica - em outros termos, a "mudança de mentalidades" jamais acontecerá espontaneamente se estiver desconectada da divisão de trabalho concre ta - podemos faze $r$ uma abordage $m$ his tórica e periodiza$\underline{\text { la; }}$

- estas relações sociais se baseiam antes de tudo em uma relação hierárquica entre os sexos, trata-se de uma relação de poder, de dominação (KERGOAT, 2010, p. 4) ${ }^{64}$.

Não se trata de colocar uma preponderância cega da categoria classe, mas a de não desconsiderá-la também como categoria importante para análise, a partir de uma ótica feminista, e que possa oferecer caminhos para a compreensão de outras relações que precisam ser consideradas, como a questão de raça-etnia.

Mesmo diante de questões de desigualdades flagrantes calcadas em questões econômicas, como as diferenças salariais e a dupla/tripla jornada de trabalho, parte do feminismo tem afirmado que a classe enquanto categoria não é importante ou suficiente para entender as desigualdades de gênero.

Coloca-se, como já mencionamos neste trabalho, que se trata de uma questão cultural que nada ou pouco tem a ver com a classe. Por outro lado, há mulheres que mesmo negam que são oprimidas porque parecem conseguir, individualmente, superar o machismo nas suas relações com os homens e com a sociedade:

Tomemos um outro exemplo da análise das propriedades das relações sociais: o sentimento de muitas mulheres, e em particular de muitas mulheres jovens, de que a igualdade está garantida ou pode ser realizada rapidamente, de que o sucesso profissional é possível e a divisão das tarefas é um problema de negociação entre os indivíduos que compõem um casal, uma questão de simples "boa vontade". Este sentimento é evidentemente paradoxal, pois ele não corresponde à realidade, tal como a vivenciamos, tampouco corresponde às estatísticas. Essa ilusão vem do fato de que tanto especialistas como leigos

${ }^{64}$ Sem grifo no original. 
freqüentemente misturam dois níveis distintos de realidade, o das relações intersubjetivas e o das relações sociais. As relações intersubjetivas são próprias dos indivíduos concretos entre os quais se estabelecem. As relações sociais, por sua vez, são abstratas e opõem grupos sociais em torno de uma disputa [enjeu].

A autora acredita que a percepção das relações sociais de sexo como uma relação social, para além de relações intersubjetivas, em que uma ou outra mulher individualmente consiga um padrão menos opressor em suas relações com os homens, explica muito de alguns paradoxos:

(...) simultaneamente à melhora da situação da mulher, em particular no mercado de trabalho, ocorre a persistência, às vezes mesmo a intensificação, da divisão sexual do trabalho. "Tudo muda, mas tudo permanece igual". Esse paradoxo me parece bastante ilustrativo dos impasses que um tipo de pensamento que segmenta as relações sociais, que os considera isoladamente, enfrenta. Aminha tese, no entanto, é: as re lações sociais são consubstanciais; elas formam um nó que não pode ser desatado no nível das práticas sociais, mas apenas na perspectiva da análise sociológica; e as relações sociais são coextensivas: ao se desenvolverem, as relações sociais de classe, gênero e "raça" se reproduzem e se co-produzem mutuamente (KERGOAT, 2010).

Classe, sexo, raça/etnia e origem... Kergoat reivindica uma leitura das desigualdades entre classe-sexo-origem como relação social, ou seja, como uma "relação antagônica entre dois grupos sociais, instaurada em torno de uma disputa [enjeu]. É uma relação de produção material e ideal" (KERGOAT, 2010).

Mas não só isso, ela entende que essas relações sociais não podem ser lidas de forma isolada, mas devem ser vistas como coexistentes e coextensivas, e usa a metáfora do "nó" para representar essa articulação de opressões.

Voltando à questão das relações sociais e relações intersubjetivas mais progressistas: o que se tem, portanto, é que algumas mulheres e homens conseguem modificar parte de suas relações a nível individual e ser mais livres, mas há algo que foge de seu domínio colocando a questão para além das soluções fechadas nas situações particulares:

Voltemos ao paradoxo. A participação da mulher no mercado de trabalho aumenta, mas as segmentações, horizontais e verticais, entre empregos masculinos e femininos, perduram. As desigualdades de salário persistem, e 
as mulheres continuam a assumir o trabalho doméstico. A meu ver, no entanto, isso não representa nenhuma aporia ou contradição interna às relações sociais de sexo, mas aponta para o fato de que o capitalismo tem necessidade de uma mão-de-obra flexível, que empenhe cada vez mais sua subjetividade: o trabalho doméstico assumido pelas mulheres libera os homens e, para as mulheres de alta renda, há a possibilidade de externalização do trabalho doméstico para outras mulheres (KERGOAT, 2010).

Embora concordemos que as mulheres do campo e da cidade, bem como as negras e brancas enfrentem essa questão de forma diferenciada, há dois princípios que parecem ser aplicáveis a todas, no que diz respeito ao peso que (não) é dado ao trabalho que executam frente ao trabalho executado pelos homens: o princípio da separação e da hierarquização.

O primeiro dos princípios informa que há trabalhos tidos como "de homem" e trabalhos tidos como "de mulher", o segundo nos coloca que essa divisão é tida não de forma complementar, cada qual com igual valor, mas os trabalhos não têm o mesmo peso na sociedade, sendo posicionados de forma hierárquica.

Há, portanto, uma divisão do trabalho que não é baseada em complementaridade, mas que dá sustentação a uma relação de poder entre homens e mulheres que passa pelo mundo do trabalho. Segundo Kergoat (2010), em resumo:

A divisão sexual do trabalho é a forma de divisão do trabalho social decorrente das relações sociais de sexo; esta forma é adaptada historicamente e a cada sociedade. Ela tem por características a destinação prioritária dos homens à esfera produtiva e das mulheres à esfera reprodutiva e, simultaneamente, a apreensão pelos homens das funções de forte valor social agregado (polític as, religiosas, militares, etc...).

Esta forma de divisão social do trabalho tem dois princípios organizadores: o princípio de separação (existem trabalhos de homens e trabalhos de mulheres) e o princípio de hierarquização (um trabalho de homem "vale" mais do que um trabalho de mulher).

O que é importante destacar de início é que "trabalho de homem" e "trabalho de mulher" não dizem respeito a conteúdos fixos, mas são categorias plásticas que admitem uma sorte variada de conteúdos, a depender do contexto e do momento histórico verificado. O que há em comum dentro dessa variedade, no entanto, é a hierarquia mencionada entre eles, de modo que, 
sendo a tarefa considerada importante, pertence a um; sendo considerada de menor importância, pertence a outra.

Um trabalho considerado de mulher em determinado momento histórico pode vir a se tornar um trabalho de homem em outro momento. Basta que venha a ganhar maior importância social, política e/ou financeira.

Da mesma forma, um trabalho tido de homem e/ou realizado pelo Estado como política social pode vir a ser compreendido como um trabalho privado, não remunerado e feminino.

Vemos que, em períodos de estabilidade econômica, trabalhos relacionados a espaços como lavanderias, restaurantes, hospitais podem ser ocupados por homens, desde que estes sejam remunerados; mas, à medida que se entra em uma situação de crise, os primeiros itens a ser cortados versam sobre esses trabalhos que são assumidos pelas mulheres que os executam gratuitamente, como forma de garantir a sustentabilidade mínima naquela situação.

No mesmo sentido, podemos pensar na grande sorte de trabalhos executados pelas camponesas de forma gratuita relacionado ao cuidado das chamadas "miudezas", como o leite, os ovos, as ervas curativas, o preparo das refeições, a lavagem das roupas, a horta para consumo familiar. Gratuita, sim, mas com conteúdo econômico flagrante, visto que o que é produzido "dentro de casa" não se precisa comprar "na rua". Os trabalhos, no entanto, embora fundamentais, não são valorizados no núcleo. O roçado, a atividade "mais importante", é a que pode vir a trazer um retorno financeiro e é coordenado pelos homens

Por outro lado, em um dado contexto, as mesmas funções podem ser, em tese, executadas tanto por homens quanto por mulheres. Aqui, o princípio se manifestará conferindo uma maior remuneração aos homens e menor pras mulheres, como já foi exposto no item anterior $^{65}$.

Em outras palavras, o par de princípios diz o seguinte: os trabalhos pouco ou não remunerados, rejeitados, desconsiderados quanto à sua função produtiva ou pouco rentáveis, pertencem às mulheres; mas, à medida que essa determinada função, antes desprezada, ganha

\footnotetext{
65 Já comentamos esse assunto no tópico anterior, mas não cus ta adensar como exemplo o discurso realizado por Patrícia Arquette durante a premiação do Oscar 2015, como atriz coadjuvante: "A todas as mulheres que deram à luz todo pagador de impostos e cidadão desta nação. Nós temos lutado pelos direitos igualitários de todos os outros. É nossa vez de ter salários iguais de uma vez por todas, e direitos iguais para mulheres nos Estados Unidos da América", momento em que questionou o porquê dos homens em Hollywood receberem salários mais altos que as mulheres. Disponível em: <http:/g1.globo.com/pop-arte/oscar/2015/noticia/2015/02/oscar-2015-e marcadopor-discursos-em-defesa-dos-direitos-humanos-veja.html>. Acesso em: 27 fev. 2015.
} 
relevo social, econômico ou político, ela passa das mãos das mulheres para a dos homens e são estabelecidos uma série de signos que desaconselham ou mesmo criam redes de obstáculos que dificultam ou até proíbem às mulheres o acesso ao poder gerado em decorrência dessas funções.

Temos, portanto, que a própria divisão dos trabalhos em esfera de "produção" e "reprodução", colocando o primeiro como importante para a economia clássica e o segundo como desprezível ou pouco importante para a análise, é problemática, visto que o conteúdo dos conceitos não é fechado.

Segundo Mathieu:

\begin{abstract}
Aunque en teoría, la división del trabajo entre los sexos pueda ser considerada, tal como lo señala Lévi-Strauss, como la prohibición para cada sexo de realizar las tareas del otro, se ha podido demostrar que de hecho, no existen actividades propiamente femeninas (Tabet 1979). En cambio, en cada sociedad, ciertas tareas están prohibidas para las mujeres, y esto según el grado de tecnicidad de las herramientas, reservándose los hombres las posibilidades de control de los medios de producción claves y de los medios de defensa (de allí su poder sobre la organización simbólica y política). (MATHIEU, 1989, p. 167)
\end{abstract}

À medida que dados da dita "esfera de reprodução" possam ser rentáveis, estes podem ganhar o status de atividades produtivas, sendo facultado aos homens a ocupação do espaço, ou mesmo sendo-lhes garantida a possibilidade de dominação deste por eles, à medida que a atividade agregue mais valor. Essa divisão flexível é coordenada por relações de poder fundadas no sexo e outras relações sociais e que tem repercussão econômica e/ou política garantindo a superioridade de um sobre a outra.

A teoria apresentada ilustra bem o que se apresenta como um dos grandes desafios para o Movimento de Mulheres Camponesas, questão que já foi comentada, mas que retomamos: o de valorizar o trabalho desempenhado pelas mulheres, pautando a sua hegemonização e garantir que sejam as mulheres as protagonistas desse processo.

Dentre um dos objetivos do movimento, está o de pautar um projeto de agricultura camponesa erigido com base em conhecimentos que as mulheres acumularam a partir de sua posição da divisão sexual do trabalho, como o de diversidade na produção e de produção de alimentos mais saudáveis sem o uso de agrotóxicos, agregando-lhes valor. 
Seria, pois, de "fazer acontecer a mulher", valorizar seus conhecimentos e da sua posição na divisão sexual do trabalho, conferindo-lhe mais poder nas relações econômicas, políticas e sexuais, colocando que o modo de produção que elas dominam é o que deva ser hegemonizado porque mais justo socialmente e que garante maior sustentabilidade para os seres humanos e o planeta.

A questão da agroecologia tem sido cada vez mais valorizada, inclusive economicamente diferenciada porque agregou valor, colocando-se para um público seleto que possa pagar por ela ${ }^{66}$. Políticas públicas têm surgido em torno da questão. Ainda que não hegemônica, tem sido timidamente colocada em pauta.

O desafio do MMC tem sido o de levar a questão, mas de não perder a possibilid ade de aumento do poder das mulheres no campo e de uma relação mais igualitária com os homens do acampamento/assentamento, quer sejam seus companheiros amorosos ou não. Um exemplo claro do exposto é o do que tem sido realizado para garantir que os projetos financiados pelo governo para o favorecimento de cultivo agroecológico contemplem a questão das mulheres, garantindo cota mínima de participação de técnicas na gestão dos projetos.

Como já dissemos, sempre que as questões relegadas às mulheres implicam maior poder, essas mulheres podem ser expurgadas dos processos de forma mais sutil ou mesmo bem gritante.

${ }^{66}$ Essa questão será melhor detalhada no próximo capítulo. 


\section{CAPÍTULO 3: "QUANDO UMA MULHER AVANÇA, NENHUM HOMEM RETROCEDE"? CONVENCENDO A SOCIEDADE E OS PRÓPRIOS MOVIMENTOS DO CAMPO SOBRE O DIREITO A UMA VIDA SEM VIOLÊNCIA PARA AS CAMPONESAS}

O trabalho empreendido até então versou acerca da configuração das bases do Movimento de Mulheres Camponesas (MMC) dentro do feminismo. Partimos de um diálogo com o que tem sido produzido pelo feminismo acadêmico acerca do que é diversidade e unidade entre mulheres; passamos por um ligeiro aprofundamento da discussão sobre identidade, discutindo acerca do traço que as une enquanto movimento: a classe em articulação com as relações sociais de sexo, tentando alcançar uma visão diferenciada acerca do que é violência contra a mulher.

Avançaremos, neste último ponto, a partir de uma pequena crítica à obra de Roberto Lyra Filho, a respeito do tratamento da questão das mulheres. O autor foi escolhido, dentro da teoria do Direito, porque reconhecemos que, sem sombra de dúvidas, ele abre o caminho para que se perceba a participação de classes e grupos sociais na disputa e conformação do Direito. A crítica virá no sentido de lançar pontos para aprofundamento, dentre os seus estudiosos, sobre a necessidade (ou não) de integrar sua obra, a partir, especificamente, das considerações que já realizamos sobre o "grupo social" "mulheres" e a "classe" "camponesas".

Finalmente, a partir da teoria da dialética social do Direito, desenharemos o quadro de disputa entre classes e grupos sociais no campo, visitaremos a práxis do MMC, contando um pouco da história das ações adotadas por essas mulheres em movimento na luta pelo direito a uma vida sem violência contra as camponesas, em duas perspectivas: uma de confronto ao sistema, a partir do que Lyra Filho chamou de "atividade anômala", e de reforma do sistema.

Esperamos, com isso, dar nossa contribuição para o enfrentamento à violência contra as mulheres dentro de uma perspectiva mais ampla, possibilitando a integração da categoria de classe social ao debate. 


\subsection{O que é Direito? Releituras de Roberto Lyra Filho a partir do feminismo}

Quando o assunto é "Direito", o Movimento de Mulheres Camponesas, tal como outros movimentos sociais, tem assertivas que parecem andar em uma direção diametralmente oposta à de classes e grupos dominantes, reverberada, por sua vez, pelas instituições jurídicas e a grande mídia.

Vejamos alguns trechos das entrevistas com as lideranças do MMC a respeito do tema “o que é direito?”:

$\mathrm{E}$ as ordens não são para dar direito, é muito para resguardar a propriedade, muito mais quem tem posses do que quem tem de fato direitos básicos de alimentação, de terra, de saúde, de previdência, né? Então, é necessário que os movimentos populares usarem da desobediência para garantir os seus direitos de fato. Então, eu acredito na desobediência. Eu acho que as leis não tão aí para gente obedecer de cabo a rabo, de maneira nenhuma. O que é bom, beleza, vamos garantir, mas sempre a gente tem que ter a ousadia de melhorar ela. A partir da realidade e das necessidades do povo. (informação verbal) ${ }^{67} 68$

Por outro lado, vejamos o que diz o discurso de quem ocupa uma posição privilegiada nas relações de poder:

\section{"Pre juízo da Aracruz com laboratório destruído passa de R\$40 milhões"} Opinião: Lei em xeque

O VANDALISMO praticado contra o laboratório da Aracruz no Rio Grande do Sul por militantes da Via Campesina, apoiados pelo coordenador nacional do MST, João Pedro Stédile, coloca em xeque o estado de direito.

AS AUTORIDADES policiais gaúchas e o Ministério Público agem de forma correta ao intimar envolvidos no atentado contra a empresa e investigar Stédile.

O IMPORTANTE é que haja consequiências concretas. Se nada ocorrer, a Lei estará desmoralizada e a impunidade estimulará crimes mais graves que esse. ${ }^{69}$

\footnotetext{
67 Entrevista concedida por Entrevistada A. [ago. 2014]. Entrevistadora: Diana Melo Pereira. Brasília, 2014. arquivo .mp3 (26'11").

68 Grifos nossos.

69 Publicado pelo jornal $O$ Globo, O País, p. 11, em 17 de março de 2006 . Disponível em: <http://pib.socioambiental.org/pt/noticias?id=20674>. Acesso em: 10 mar. 2014.
} 


\section{"MP indicia 37 pess oas por destruição da Aracruz"}

Trinta e sete integrantes da Via Campesina, rede de organizações que atuam no campo, foram denunciados à Justiça pela ocupação do horto florestal da Fazenda Barba Negra, ocorrida no dia 8 de março. Assinada pelo promotor Daniel Soares Indrusiak, a denúncia acusa as 37 pessoas de delitos de dano, furto, cárcere privado, formação de quadrilha e lavagem de dinheiro.

A Polícia Civil e o Ministério Público de Barra do Ribeiro (RS) instauraram inquérito para investigar a ocupação por centenas de manifestantes. No ataque, foram danificadas as plantações de eucaliptos e outras árvores destinadas à indústria de celulose e papel mantidas pela empresa AracruzCelulose S/A, em Barra do Ribeiro. ${ }^{70}$

Parecemos estar diante de duas visões contraditórias do Direito e suas instituições. De um lado, estão as mulheres em movimento camponês, acreditando estar legitimadas a contrariar as leis (o Direito?), caso elas não correspondem aos interesses populares.

Outro lado, respaldado por agentes do Estado, como o Ministério Público, que sequer considera que o ato da Via Campesina acima citado foi liderado por mulheres camponesas, pugna pela aplicação de sanções a um grupo (repisemos, majoritariamente de mulheres, em ação em um 8 de março) que teria, em tese, desrespeitado normas do direito penal, determinando a investigação com o objetivo de processo e criminalização dos envolvidos.

Que direito, entendido aqui como faculdade, é esse que o Movimento de Mulheres Camponesas e a Via Campesina acham que têm de não seguir a norma estatal positivada (Direito?) desde que se confronte com o que eles chamam de "interesses populares"? O direito de ir contra o Direito? Ou a norma positivada, a lei, não é Direito? Que visão é essa acerca do fenômeno jurídico? ${ }^{71}$

Uma outra pergunta que lançamos: por que as mulheres camponesas, em um 8 de março, escolhem uma ação como essa para lutar por uma vida sem violência para as mulheres?

\footnotetext{
70 Notícia publicada pelo portal Terra Notícias, em 24 de abril de 2006 . Disponível em: $<$ http://noticias.terra.com.br/brasil/noticias/0,,OI976627-EI306,00MP+indicia+pessoas+por+destruicao+da+Aracruz.html>. Acesso em: 10 mar. 2014.

71 Em primeiro ponto, temos de esclarecer que usaremos "direito" com "d" minúsculo para tratar do que a teoria tem chamado tradicionalmente de direito subjetivo. A faculdade que cada uma ou cada um tem fundado em uma ordem de onde extrai legitimidade. O Direito com " $D$ " maiúsculo refere-se mais a uma teoria do ordenamento que, para nós que seguimos a corrente "O Direito Achado na Rua”, baseada, dentre outros autores, na obra de Roberto Lyra Filho, guarda bastante semelhança com a compreensão esboçada pelo MMC, dentre outros movimentos sociais organizados, acerca do que seja Direito.
} 
A partir de uma posição que ganhou coro dentro do espaço de formação dos estudantes de Direito: o positivismo jurídico, o Direito é, em tese, organização social, baseada na aplicação de sanções organizadas a partir do monopólio estatal, com fundamento em normas préestabelecidas, segundo um também procedimento pré-estabelecido.

De todo modo, as normas - isto é, como vimos, os padrões de conduta, impostos pelo poder social, com ameaça de sanções organizadas (medidas repressivas, expressamente indicadas, com órgão e procedimento especiais de aplicação) - constituem, para o positivismo, o completo Direito (LYRA FILHO, 2005, p. 18).

Essa visão é replicada pelos profissionais que compõem as instituições jurídicas, reverberada por outras instituições (como a escola e a Igreja) e reforçada pelos meios de comunicação de massa.

Dentro dos estudos de Marx e sobre Marx, há, por outro lado, mesmo uma posição significativa que coloca que o Direito não teria a finalidade de promover o bem comum, jamais servindo aos grupos subalternos da sociedade, sendo instrumento criado por uma classe específica, a burguesia, com a finalidade de garantia da manutenção da propriedade e de seu poder na sociedade (LYRA FILHO, 1983a).

O Direito e suas instituições teriam a finalidade de garantir a manutenção do status quo e o dito monopólio da violência seria utilizado contra qualquer perspectiva de transformação da sociedade após a ascensão da burguesia ao poder (LYRA FILHO, 1983a).

Dentro da crítica à visão positivista que tem prevalecido sobre o que é direito, mas ao revés dessa posição, alguns pensadores, dentre brasileiros e estrangeiros ${ }^{72}$, colocam a possibilidade de pensar todo o Direito sobre outras bases, em diálogo (ou mesmo confrontando essa "verdade") com a obra maxiana e marxista.

Defendem que o Direito possa ser utilizado em uma perspectiva transformadora e emancipadora dos grupos subalternos (ou insurgentes). Defendem que não existe "o" Direito

\footnotetext{
${ }^{72}$ Michell Miaulle, Boaventura de Sousa Santos, Antonio Negri, dentre outros.
} 
como ordem única, mas a possibilidade de uma pluralidade de formas diversas de se propor um ordenamento para a sociedade, formas essas que podem ou não se confrontar ${ }^{73}$.

No Brasil, um autor em especial, Roberto Lyra Filho, chama nossa atenção, fato que destacamos na introdução deste trabalho e deste capítulo, não somente por ter traçado linhas interessantes acerca de vários níveis de relacionamento dos grupos da sociedade com as normas, mas por ter pensado o Direito em uma perspectiva dialética. Uma forma de ver o fenômeno jurídico que guarda relativa correspondência com a fala dos movimentos sociais, como o Movimento de Mulheres Camponesas, acerca do que seja Direito.

Por outro lado, embora a teoria lyriana nos sirva nesse aspecto, há, no esforço teórico empreendido por Lyra Filho, pequenas enunciações sobre as mulheres enquanto grupo oprimido, enunciações as quais gostaríamos de confrontar com a leitura feminista que empreendemos até o momento.

Quem sabe o trabalho preste-se a, dessacralizando a obra de Lyra Filho, operar na perspectiva de integrá-la e atualizá-la face a reflexões que o autor não conseguiu fazer, quer porque estivesse preso ao seu contexto, quer porque não tivesse se aberto a tempo para ler e acompanhar linhas do feminismo que foram suas contemporâneas.

É a que nos prestaremos no próximo tópico deste capítulo.

\subsection{Mulheres Camponesas: classe ou grupo social? Por uma perspectiva de consubstancialidade das relações no Direito}

Lyra, para chegar ao modelo da Dialética Social do Direito, que exporemos no tópico a seguir, critica anteriormente dois modelos que seriam igualmente hegemônicos na análise sociológica do Direito.

Um nomeado modelo "a" daria conta do capitalismo nos momentos de auge e teria como retrato uma ordem social construída com base no consenso, tomando contestações e contraculturas como excepcionais e objetos de repressão.

\footnotetext{
73 A título de exemplo, citamos: WOLKMER, Antonio Carlos. Pluralismo Jurídico: fundamentos de uma nova cultura no Direito. 3. ed. São Paulo: Alfa-Omega, 2001.
} 
Um nomeado modelo "b" daria conta de explicar as intensas crises do capitalismo e a flagrante existência de várias culturas em disputa, e toma os conflitos como inerentes à ordem social, que teria de fazer uso da repressão para garantia da existência da sociedade, sem, no entanto, mencionar a questão das classes sociais e do modelo econômico como ligados aos problemas culturais.

Figura 2 - Esquema A

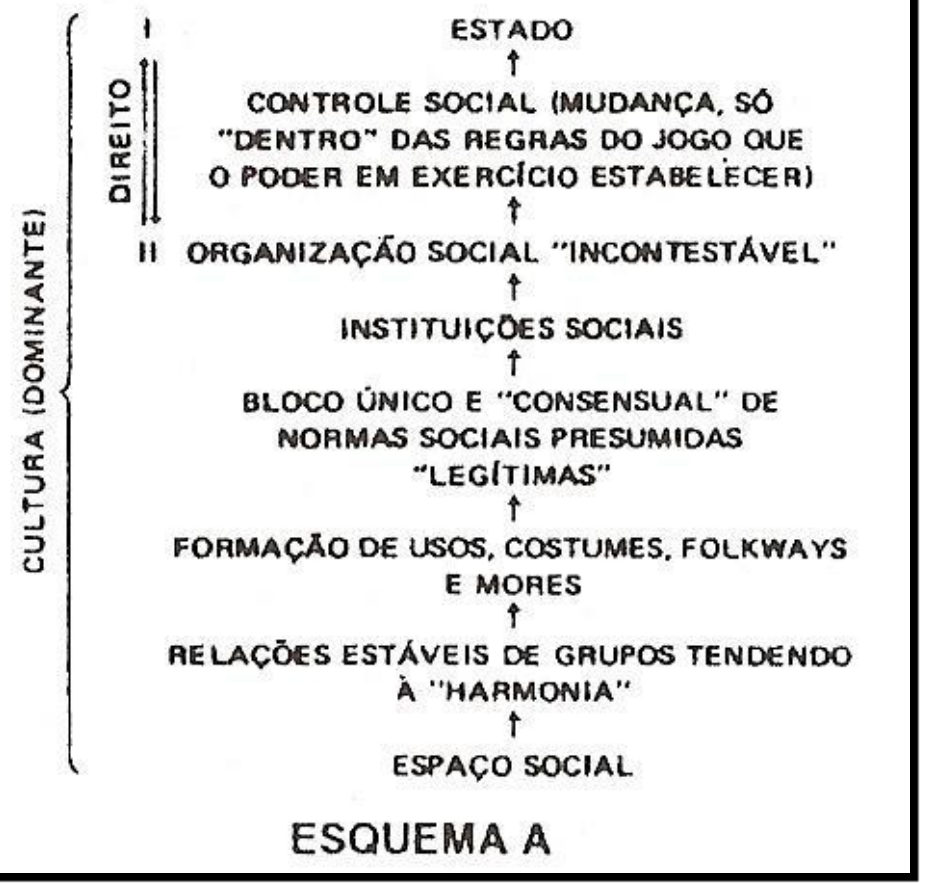

Fonte: LYRA FILHO (2005, p. 37). 


\section{Figura 3 - Esquema B}

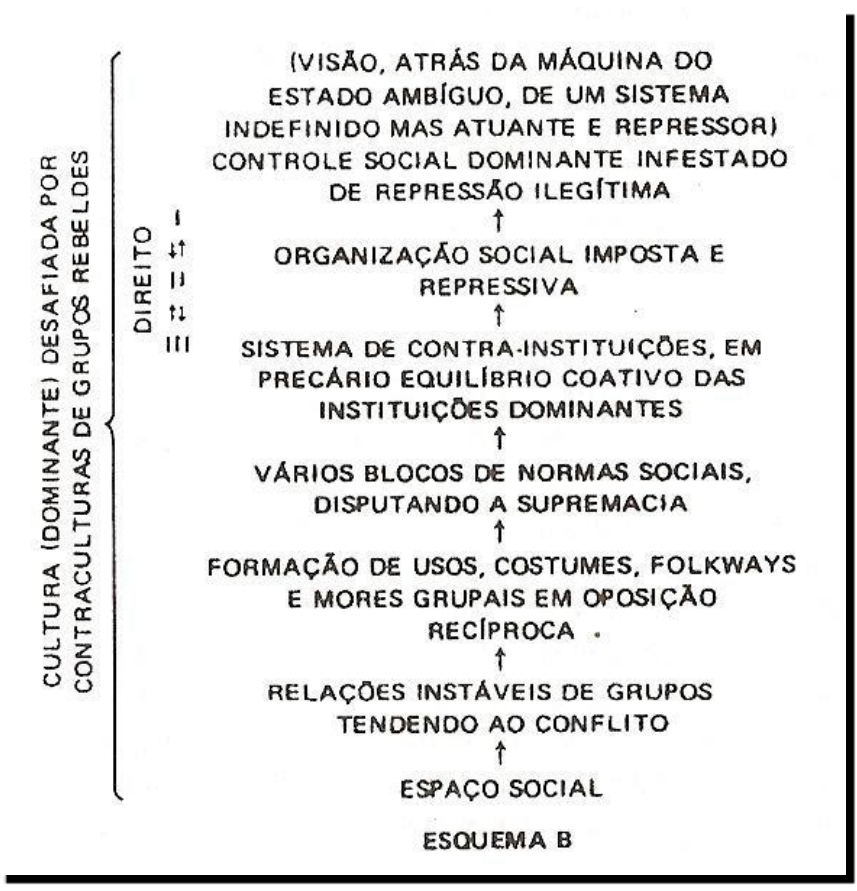

Fonte: LYRA FILHO (2005, p. 39).

Os chamados usos, costumes, flokwares e mores são normas sociais em graus variáveis:

As normas - isto é, os padrões de conduta, exigível sob ameaça de sanções (os meios repressivos, que vão das sanções difusas - não organizadas - às sanções organizadas - com órgão próprio e ritual específico de aplicação) - distribuemse em usos (práticas consagradas pela mera repetição), costumes (práticas consagradas pela força da tradição ativa e militante, como necessidade coletiva e, portanto, obrigação indeclinável de todos), folkways (costumes peculiares que definem o "modo de ser" dum povo) e mores (o setor mais vigoroso dos costumes, julgados indispensáveis para a ordem social estabelecida e que, por isso mesmo, se resguardam com normas e sanções mais severas e melhor organizadas) (LYRA FILHO, 2005, p. 35).

Lyra acusa a necessidade de se pensar o direito em uma perspectiva dialética que perceba, sim, a existência de várias culturas em disputa, mas que também integre a questão econômica e as classes sociais como elementos no modelo de compreensão do Direito.

No entanto, o próprio Lyra, quando trata da questão das mulheres, negros e grupos não heterossexuais e as respectivas opressões que os grupos sociais sofrem por serem ou o polo dominado nas relações sociais hegemônicas (mulheres, negros) e/ou mesmo negada uma 
possibilidade de existência (grupos não heterossexuais), os enquadra somente quanto ao viés cultural.

Sua libertação específica, portanto, dependeria mais de uma nova cultura de respeito aos direitos humanos que deveria ser integrada a uma paralela luta pela transformação do modo de produção da sociedade.

As menções diretas às questões dos grupos sociais aparecem bem nos momentos em que Lyra evidencia que o socialismo real por si só não dá conta de uma real transformação da sociedade se não enxerga os direitos de minorias sociais:

O fato é que não se pode reconduzir, em linha reta, qualquer fenômeno ideológico à organização sócio-econômica. Há produtos ideológicos relativamente solúveis, sem troca do modo de produção, como os há relativamente indissolúveis, mesmo quando a troca se consumou. Exemplo disto é o machismo, já citado, que se vai atenuando, em certas sociedades capitalistas, e resiste com mais vigor em determinados países de socialismo implantado, ao menos quanto à base material das relações de produção (LYRA FILHO, 2005, p. 10).

Enxerga, portanto, que há a possibilidade de articulação de oposições, mas reforça sempre que a oposição entre classes sociais não está necessariamente ligada à oposição de grupos sociais.

Temos insistido, invariavelmente, nesta referência a classes e grupos, e é preciso explicar que ela distingue o aspecto básico da oposição entre uma classe dominante, espoliadora, e uma classe dominada, espoliada, paralelamente à oposição entre grupos opressores e oprimidos, esta última oposição não estando diretamente ligada à outra. Assim é que Miaille recorda os conflitos de grupos, em termos de "minorias exigindo o dire ito à diferença", um contraste colateral (de alcance jurídico, mas não vinculado à questão sócio- econômica apenas): minorias regionalistas, minorias sexuais, minorias étnicas. Assim como deixamos registrado, quanto às ideologias, o contraste não representa, sem mais, um choque classístico, podendo dissolver-se ou subsistir, independentemente da troca do modo de produção. Citamos, por exemplo, o machismo, que mantém a opressão da mulher ou dos homossexuais, em sociedades cuja base econômica já alterou o sistema classístico e a espoliação maior da injusta distribuição da propriedade (LYRA FILHO, 2005, p. 25). 
Esse pensamento é ainda presente em um feminismo liberal "não declarado", que, "esquecendo-se" de (ou deixando de lado a) questão da classe social, a fim de que ela não "sufoque" as discussões acerca de uma mudança cultural necessária à libertação das mulheres, pensa as pautas e ações do movimento feminista e a luta por direitos desarticulados de uma mudança global na estrutura da sociedade e seu modo de produção.

No entanto, movimentos como o Movimento de Mulheres Camponesas (bem como outros movimentos, por exemplo, o de trabalhadoras domésticas, o de mulheres negras, dentre outros), que articulam classe-raça-gênero-sexualidade, amparadas por teóricas feministas socialistas ou materialistas e até de leituras dentro do pensamento dito como "pós-moderno", acusam que "sem feminismo, não há socialismo", chegando até a nomear a categoria mulheres como "classe" e não mais somente grupo social, no caso das materialistas francófonas, e enxergando que a socialização dos meios de produção e uma sociedade socialista somente existirão com a negação de apropriação dos corpos das mulheres e com o questionamento profundo das relações sociais de sexo ou de gênero.

Mas não deixa de ser compreensível a ênfase dada por Lyra. O problema da articulação entre sexo e classe, como o de outras questões relativas a grupos subalternizados, na sua afirmação e luta pela especificação de suas demandas, teve de bater de frente contra um marxismo estéril que só enxergava (e ainda enxerga em alguns grupos) a questão de classe, desmerecendo a necessidade de uma transformação da sociedade no nível da questão cultural.

As camponesas, dentro dos movimentos sociais do campo e entre seus companheiros afetivos, enfrentaram um grande desafio para que sua questão específica fosse considerada e elas pudessem se reunir de forma autônoma para reivindicar direitos que interessavam a sua classe:

Lyra, na verdade, cai, a nosso ver, em uma das armadilhas do segundo modelo sociológico apresentado acima no seu próprio esquema, quando não enxerga a dialética e coextensividade das opressões entre classe-gênero-raça e etnia-sexualidade, questões a que poderia ter chegado na década de 1980-1990, data de suas obras, a partir de um diálogo com as reflexões de parte do movimento negro e de mulheres e de suas/seus teóricas/os.

Com identidade feminista e classista e a legitimidade de quem já havia aglutinado anos de história de luta, militantes e dirigentes reafirmaram a necessidade de autonomia. Ficou explícito, no processo, que o patriarcado perpassa inclusive as organizações de esquerda. A resposta das mulheres foi 
de que elas superaram a fase de necessitar pedir licença ou favor: "quem sente e sabe do que as mulheres podem e devem são elas mesmas"; "quem sente e sabe da opressão patriarcal, além a opressão do capital, deve reagir contra ambos." (CONTE; MARTINS; DARON, 2009, p. 115).

O movimento foi criado porque se percebeu que se as mulheres, elas próprias, não se reunissem e se organizassem, continuariam submetidas aos homens, dentro e fora de casa. Mas, em lugar de se reafirmar somente como mulheres e vislumbrar a questão como cultural, reivind icam sua posição de classe.

Elas compreenderam que a posição delas de mulheres exploradas e violentadas dentro e fora de casa somente vai ser transposta se todo o sistema for transformado: "sem feminismo não há socialismo", gritam repetidas vezes como palavra de ordem e firmam posicionamento frente aos homens dos movimentos populares.

(...) há 30 anos atrás foi um período que também houve o surgimento de outros movimentos como o MST e outros movimentos, CPT... Elas faziam até parte da organização da Eclesial de Base, que é da CPT e tal... mas elas sentiam que nessa luta que se fazia pela terra, nessa luta que se fazia pelos direitos dos trabalhadores rurais, dos camponeses, que a luta das mulheres ficava sempre em segundo plano. Que não era uma prioridade lutar pelos direitos exclusivos das mulheres. Pela participação das mulheres. No caso, o movimento é pioneiro na luta, por exemplo, de reconhecer a trabalhadora rural como uma profissão que na época não era reconhecida. Então, elas sentiram que a luta tinha que ser a partir da organização e da luta das mulhe res [ênfase] que esses direitos, que esse reconhecimento quanto protagonistas, como trabalhadoras do campo e produtoras de alimentos só seria possível a partir delas, das próprias mulheres organizadas. Então, foi dessa necessidade de colocar dentro da luta maior pela mudança de sociedade, pela reforma agrária, do acesso à terra e direitos, a necessidade de que as mulheres fossem vistas, fossem protagonistas e vistas e também protagonistas pelos direitos, pela luta por direitos. Foi nesse sentido foi que elas sentiram necessidade e começaram se organizar. (informação verbal) ${ }^{74}$

Acreditamos que a visão de opressões de classes e grupos sociais como um nó que relaciona classe-gênero-raça-origem pode vir a ser de grande valia para que se pensem as

\footnotetext{
${ }^{74}$ Entrevista concedida por Entrevistada B. [ago. 2014]. Entrevistadora: Diana Melo Pereira. Brasilia, 2014. arquivo .mp3 (52'36").
} 
problemáticas de forma mais complexa, ou, usando a categoria marxista, com vistas a perceberem a totalidade das relações sociais.

Essa visão chama-nos atenção para, de um lado, pensarmos as políticas públicas de forma integrada a um posicionamento econômico levado a cabo pelo Estado. Permite-nos compreender, por outro lado, como os movimentos de contestação podem ser fragilizados em seu âmago por perpetuarem, entre si, relações de opressão.

\subsection{A Dialética Social do Direito e as relações de sexo e classe no campo no Brasil}

\subsubsection{Breves notas sobre a crítica de Lyra Filho às ideologias jurídicas}

Lyra Filho, em uma de suas obras mais conhecidas, "O que é Direito", de 1985, enunciou linhas de uma teoria complexa a qual denominou "Dialética Social do Direito". Retomaria o assunto em obras como "Direito do capital e direito do trabalho" (1982), "Karl, meu amigo: diálogo com Marx sobre o Direito" (1983), "Humanismo dialético (I)" (1983) e "Para uma Visão Dialética do Direito" (1999), as quais nos deteremos em menor ou maior grau. Lyra tocou na questão em outras obras. ${ }^{75}$

Na pequena e densa obra "O que é Direito", Lyra parte da explicação sobre a categoria ideologia, identificando-a como forma de pensamento construída como fato social, situada materialmente, e que é introjetada psicologicamente como "verdade", dando-lhe ares metafísicos. Destaca que toda forma ideológica tem sua face de "verdade" e uma face que escamoteia a realidade, a depender do ponto de vista e interesses daquele que analisa o mundo.

Segue colocando que as duas correntes mais fortes que discorrem acerca do que é Direito, o positivismo jurídico e o jusnaturalismo, são ideologias, ou seja, de uma banda enunciam verdades, de outra atuam como formas de escamoteamento da realidade. Faz a crítica e indica que há uma outra forma de conceber o Direito: a dialética.

\footnotetext{
75 Vide trabalho de dissertação de mestrado de Pedro Feitoza: "O Direito como legítima organização social da liberdade: a teoria dialética de Roberto Lyra Filho", de 2014.
} 
Apresenta, em primeiro lugar, o positivismo jurídico, tese que tem se colocado como hegemônica na sociedade. ${ }^{76}$

Critica-o e aponta que o positivismo, quer em suas versões legalista, mais diretamente, quer em suas versões psicologista ou historicistas ou fenomenológicas, de forma mais "amena", defende o instituído. A permanência de uma ordem que foi inaugurada pela burguesia, aliada a classes e comportamentos retrógrados, quando the interessava, como uma elite agrária e as igrejas mais conservadoras; ancorando-se, a seu bel prazer, na lei que produzia enquanto ocupante dos órgãos legislativos.

A lei é entendida pelo positivismo como direito, um legalismo que restringe a compreensão da norma, à norma específica positivada pelo Estado, dentro de um formato e seguindo um procedimento específico pré-estabelecido. A ideia era a de garantir uma segurança contra arbitrariedades e influências da política sobre o Direito. Um dos problemas é que quem pré-estabelecia essas normas procedimentais, era exatamente o Estado: "Todas as formas do positivismo, assim, rodam num círculo, porque, a partir do legalismo, giram por diversos graus para chegarem ao mesmo ponto de partida, que é a lei e o Estado" (LYRA FILHO, 2005, p. 22).

Ora, se a ideia era tornar o Direito "limpo" de qualquer influência, como centrar sua produção em um espaço iminentemente político e de disputa? Era a grande questão que os positivistas ocultavam com ficções, uma delas a autolegitimação do próprio sistema; outra, a que o Estado de Direito controlaria os governantes, como se não fossem os próprios governantes a elaborar a norma estatal.

No fim das contas, sob o manto do Estado de Direito, as classes e os grupos dominantes usavam os aparelhos de justiça e segurança do Estado para impor ao restante do povo os seus próprios interesses:

Quando o positivista fala em Direito, refere-se a este último - e único - sistema de normas, para ele, válidas, como se ao pensamento e prática jurídicas interessasse apenas o que certos órgãos do poder social (a classe e grupos dominantes ou, por elas, o Estado) impõem e rotulam como Direito (LYRA FILHO, 2005, p. 18).

\footnotetext{
76 Versão hegemônica não só dentre aqueles que "ensinam”, nos cursos de Direito, ou "aplicam” o Direito, como o Minis tério Público e o Judiciário; como é reforçada pelas instituições dominantes como a Igreja cristã (em seu viés mais conservador, também hegemônico).
} 
No entanto, a crença em que a positivação do direito garante justiça, "justo porque ordenado", em uma ordem com ares de democrática, lança problemas para classes e grupos que tradicionalmente ocuparam posições de poder, quando as classes populares e os grupos subalternos conseguem, por meio de eleições, ascender a algumas posições dentro do aparelho estatal, que produz as leis e detêm o poder de polícia ou dentro das profissões que são mais dirigidas a interpretar e aplicar as leis. Outras estratégias, como golpes e silenciamentos ou ridicularizações, são utilizadas, mas não sem apresentar uma fissura, uma contradição.

Apresenta o jusnaturalismo como teoria que, em tese, diferencia direito positivo e justiça, mas que, na prática, tende a procurar em entidades fora da norma (como Deus, a natureza ou a racionalidade) a legitimidade para o direito positivo e, principalmente, para a ordem social instituída dentro ou fora dessa norma.

Modos de ordenar as relações sociais e seus conflitos, que interessam a uma classe e grupos sociais em específico, são generalizados em nome de um dito "bem comum” e tanto as afirmações, como as negações, do direito positivo, são elaboradas de modo a sustentar a posição de classes e grupos que detêm o poder na sociedade.

Da mesma forma que a crença no direito positivo como justiça, a crença no direito natural como justiça também abre a possibilidade para que a ordem que foi estabelecida (e que se coloca como hegemônica na sociedade) seja questionada; na medida em que afirma que o fato de o direito ser positivado (tendo o Estado como seu alforje - e as classes sociais que o dirigem) não garante que ele seja justo.

Não foi uma leitura do direito natural (antropológica) que justificou a própria tomada do poder político pela burguesia nas primeiras revoluções que estabeleceram o Estado de Direito? O que dizer, principalmente do documento de Independência dos Estados Unidos da América, que mencionava: "Consideramos estas verdades como auto-evidentes, que todos os homens são criados iguais, que são dotados pelo Criador de certos direitos inalienáveis, que entre estes são vida, liberdade e busca da felicidade." ?77

Mas, como Lyra nos relembra:

Está visto que, chegando ao poder, a burguesia, como já acentuamos, descartou o seu iurisnaturalismo, passando a defender a tese positivista: já

${ }_{77}$ BOBBIO, Norberto. Era dos direitos. Elsevier Brasil, 2004. 
tinha conquistado a máquina de fazer leis e por que, então, apelar para um Direito Superior? Bastava a ordem estabelecida (LYRA FILHO, 2005, p. 26).

Lyra traz autores que investigaram uma possibilidade emancipadora e de combate para o direito natural, como Miaille, Mannheim ou Ernest Bloch, aos quais não nos deteremos de modo a não alongar demais este trabalho; mas Lyra, reconhecendo essa potencialidade, da mesma forma que reconhece a possibilidade do direito positivo enquanto instrumento de emancipação, propõe uma síntese dialética para o Direito, considerando os dois lados de verdade do direito positivo e direito natural, sem as pechas do jusnaturalismo e juspositivis mo:

\begin{abstract}
Somente uma nova teoria realmente dialética do Direito evita a queda numa das pontas da antítese (teses radicalmente opostas) entre direito positivo e direito natural. Isto, é claro, como em toda superação dialética, importa em conservar os aspectos válidos de ambas as posições, rejeitando os demais e reenquadrando os primeiros numa visão superior. Assim, veremos que a positividade do Direito não conduz fatalmente ao positivismo e que o direito justo integra a dialética jurídica, sem voar para nuvens metafísicas, isto é, sem desligar-se das lutas sociais, no seu desenvolvimento histórico, entre espoliados e oprimidos, de um lado, e espoliadores e opressores, de outro (LYRA FILHO, 2005, p. 15-16).
\end{abstract}

O método escolhido para desenhar o fenômeno jurídico é o materialismo histórico e Lyra trabalha a partir das categorias da totalidade, a leitura do Direito enquanto fato social, construído, portanto, historicamente pelas lutas de classes e grupos sociais.

O próprio Lyra, no entanto, acusa desde já que é um modelo em construção e que está aberto a erros, incompletudes em sua enunciação:

A tarefa a realizar, numa visão da dialética social do Direito, exige, portanto, que se delineie, ainda que toscamente (para aperfeiçoamento constante), um modelo sociológico dialético. (...) Está visto que "termo" significará o ponto final desta obra, e não a idéia presunçosa de que se oferece aqui a "essência" do Direito, para não haver mais o que tirar nem pôr em tal abordagem (LYRA FILHO, 2005, p. 41-42).

E desenha um complexo modelo que reproduzimos abaixo (página seguinte): 
Figura 4 - Esquema C (modelo dialético)

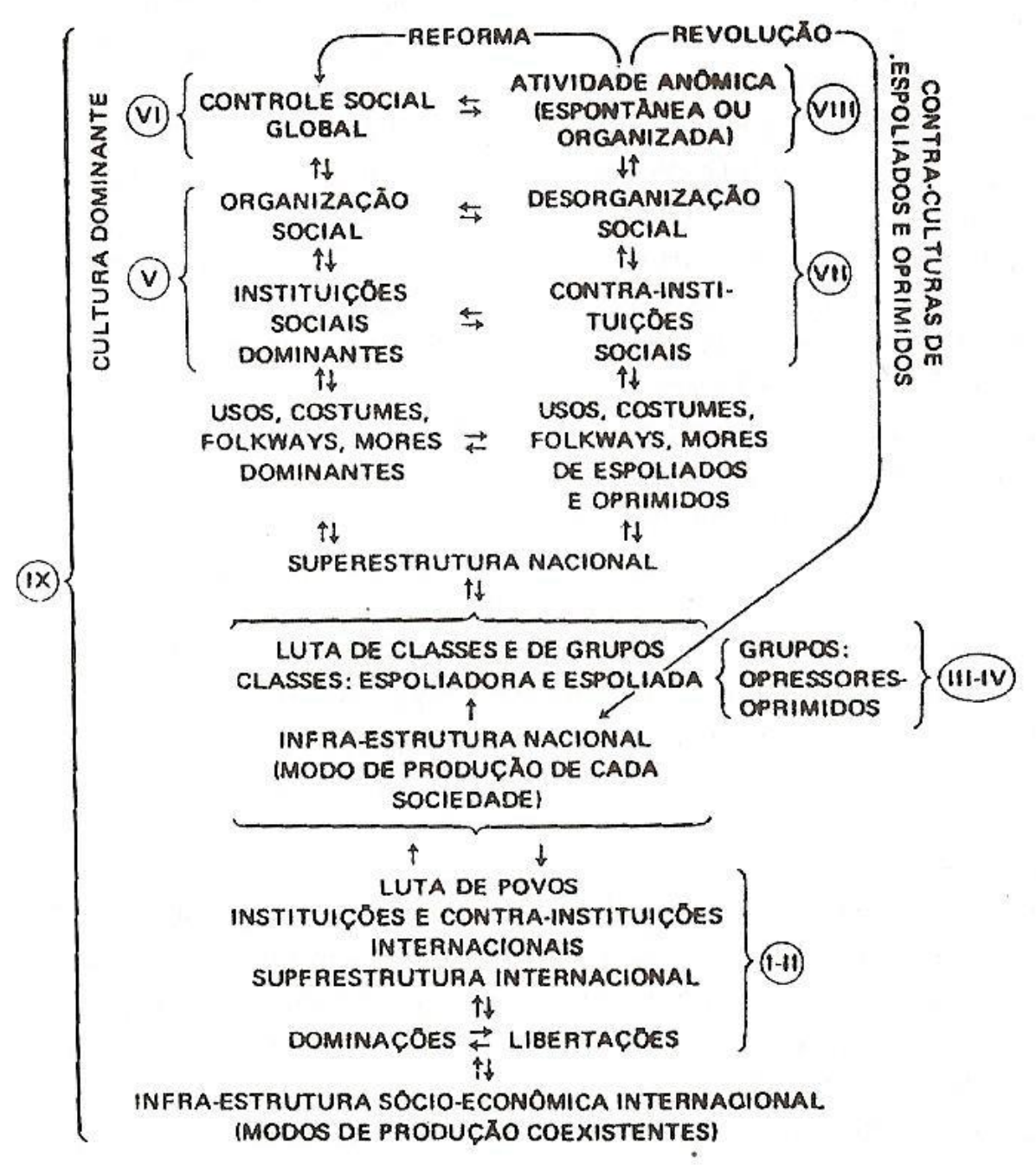

\section{ESOUEMA C (MODELO DIALETTICO)}

Fonte: LYRA FILHO (2005, p. 46). 
Sigamos com apoio no modelo e algumas de suas categorias para discorrer sobre a visão de direito e violência, a partir do campo e do Movimento de Mulheres Camponesas.

\subsubsection{O Direito não se limita a aspecto interno do processo histórico. Ele tem raiz internacional}

Lyra começa a explanação sobre seu esquema a partir da análise do Direito construído a nível internacional, evidenciando que os sistemas jurídicos nacionais não estão isolados, mas atuam de forma articulada ou em conflito com outras ordens coexistentes em outros Estados Nacionais. Esse diálogo/confronto a nível internacional ocorre ao som e ritmo dos modos de produção que podem ou não ser correspondentes, que podem ou não estar alinhados.

Há, pois, Direito no âmbito internacional, segundo Roberto Lyra Filho, no sentido mais "duro" do termo, com a possibilidade de estabelecimento de normas e aplicações de sanções no caso de seu descumprimento, mesmo quando em conflito com normas internas. Isso não quer dizer que escape da dialética social, como veremos, e repercuta na aplicação ou não de normas estabelecidas.

Lyra chama atenção para o fato de que há a possibilidade de que haja uma atuação progressista a partir de normas internacionais, embora reconheça que os princípios emancipatórios que poderiam reger as relações entre Estados, são negligenciados quando não interessa às forças dominantes na sociedade.

I - O Direito não se limita a aspecto interno do processo histórico. Ele tem a raiz internacional, pois é nesta perspectiva que se definem os padrões de atualização jurídica, segundo os critérios mais avançados. (...) O princípio da autoderteminação dos povos e soberanias nacionais (que, aliás, o imperialismo a todo instante ofende escandalosamente) não impedem a atuação, até, das sanções internacionais, na hipótese das mais graves violações do Direito (LYRA FILHO, 2005, p. 84).

A legislação internacional constrói-se, pois, em meio a um caldo de disputas econômicas e por poder político, e as ações progressistas enfrentam, no que diz respeito à garantia de direitos na prática, a força de classes e grupos que detêm o poder. Mas é inegável que ao nível do discurso, principalmente desde a Segunda Guerra Mundial e o genocídio do povo judeu, tem 
sido cada vez mais difícil negar humanidade a algum grupo ou classe social para justificar sua dominação.

O que se tem ainda com muito vigor, no entanto, é a utilização de força ilegítima a partir de um discurso ideológico paternalista, principalmente chefiado pelo imperialismo norteamericano, que "justifica" o desrespeito à autodeterminação dos povos para a consecução do "bem" diante de uma dita incapacidade de povos frágeis frente a supervilões (forjados com a própria colaboração norte-americana e de seus aliados), como Sadamm Hussein e Bin Laden. Há que se destacar, no entanto, que essa ideologia não convence tanto, mas, neste caso, é tão somente o adereço que ornamenta as armas e o poderio militar que garantem, por si só, o convencimento necessário.

Embora todas as problemáticas lançadas, há, em tese, ventos que sopram no sentido de construção e defesa de uma legislação a nível internacional que respeite os direitos humanos ${ }^{78}$ e, por algumas vezes, consegue-se dar algum nível de efetividade a essas normas.

A verdade, entretanto, é que o direito entre nações luta para não ficar preso ao sistema de forças dominantes, e em que pesem as felizes contradições a sua forma inter-estatal (entre Estados) reproduz, no ângulo externo, a obstrução (...) quanto ao direito estatal. Daí a expressão jurídica paralela em uma dialética estabelecida pelos povos oprimidos e expoliados. Exemplo disso é o conjunto de princípios jurídicos, consagrados na carta de Argel $(1977)^{79}$, em que os povos oprimidos formularam a sua quota de direitos postergados (LYRA FILHO, 2005, p. 47).

Mencionando de forma mais específica em relação a esses avanços, no que diz respeito às questões sobre violência contra as mulheres de um modo geral e, de uma forma mais

\footnotetext{
${ }^{78}$ A categoria "direitos humanos" apresentou grande vigor na década de 1990 e na primeira década dos anos 2000, mas que se encontra perdendo força, face à necessidade de que seja inserida a pauta econômica nas preocupações e problematizações em meio de mais uma crise do capitalismo. Não podemos esquecer, no entanto, que, embora progressista, a legislação de direitos humanos a nível internacional, levada a cabo pelas instituições supraestatais compostas pelos Estados Nacionais e os órgãos da ONU, diz muito a respeito de grupos sociais, como mulheres, grupos GLBTTT e negros, mas engendra-se em uma perspectiva liberal, tendendo a esquecerqualquer noção de classe e o questionamento ao modo de produção. Tal postura implica, a nosso ver, dificuldades concretas na superação de opressões vivenciadas por esses grupos sociais. Voltaremos a esse assunto mais à frente, inclusive em crítica à compreensão de Lyra com a colaboração do feminismo.

${ }^{79}$ A Carta de Argel, ou Declaração Universal dos Direitos dos Povos, enunciou os chamados direitos de terceira ou quarta dimensão: direito ao desenvolvimento, à paz, e à participação no patrimônio comum da humanidade, à democracia. Informação disponível em: <http://www.dhnet.org.br/direitos/anthist/margarid.htm> e <http://www.escoladegoverno.org.br/artigos/115-direitos-humanos-declaracao-1948>. Acesso em: 10 dez. 2014.
} 
específica, nas suas relações familiares, vê-se que os movimentos feministas a nível internacional conseguiram imprimir um vento ligeiramente progressista desde a década de 1970, na produção de legislações a nível internacional, considerando a necessidade de eliminação de toda forma de violência contra as mulheres (PIOVENSAN, 2009 p. 196-204).

Dizemos "ligeiramente" por dois motivos.

O primeiro diz respeito a problemas referentes ao conflito universalismo/culturalis mo, cada qual com suas perspectivas opressoras e silenciadoras de minorias políticas como as mulheres. Lembrando que, embora a Convenção Sobre a Eliminação de Todas as Formas de Discriminação contra a Mulher (CEDAW) tenha sido a convenção com maior número de adesões, 185 no total, até 2009, ela também "enfrenta o paradoxo de ser o instrumento que recebeu o maior número de reservas formuladas pelos Estados dentre os tratados internacionais de direitos humanos" (PIOVESAN, 2009, p. 196-197). Uma das cláusulas que mais encontrou rechaço foi a que previa a igualdade entre homens e mulheres na família sob a acusação de que era de caráter imperialista.

O segundo decorre da visão fragmentada dos direitos humanos em uma perspectiva mais liberal que tende a ver a questão como somente um problema cultural repercutindo sobre ações individuais. Nem vislumbra que as opressões contra as mulheres e outros grupos estão articulados com o capitalismo e a divisão sexual e racial do trabalho, como, por vezes, colocam o problema como de fundo exclusivamente individual, como uma questão psicológica/psiquiátrica pessoal, deslocando o foco da necessidade de empoderamento das mulheres para ações dirigidas ao convencimento dos homens a resolverem seus conflitos familiares sem a utilização da violência.

Consideramos, também, como resultado das ações de luta de grupos feministas articuladas a nível internacional, a pressão que foi exercida para a criação de uma legislação específica para o enfrentamento à violência contra as mulheres no Brasil. Lei essa elaborada a partir da conjuntura favorável com a consideração de responsabilidade do Estado brasileiro por omissão frente ao caso específico de Maria da Penha, que viria ter seu nome na lei que trata sobre a violência doméstica e familiar no Brasil ${ }^{80}$.

\footnotetext{
80 Maria da Penha e outros peticionários dirigiram-se à Comissão Interamericana de Direitos Humanos para reclamar do governo brasileiro um posicionamento geral frente aos casos de violência doméstica no Brasil e, de modo específico, frente à falta de resposta do Estado face às violências cometidas contra Maria da Penha por seu marido, que culminaram em sua paraplegia e outros danos morais, psicológicos e materiais. O crime, investigado e processado, já se alongava por 15 anos em razão de vários recursos sem amparo legal (no que diz respeito à observância de prazos preclusivos e prescritivos para ajuizamento) e poderia alcançar a prescrição de pretensão
} 
Mas os Estados Nacionais e as organizações da ONU não são os únicos atores no processo. Movimentos Sociais organizados a nível internacional também somam na correlação de forças que tencionam para a ocorrência de mudanças a nível global e local, nem sempre se conformando com o que está posto, pleiteando a transformação das normas e pressionando as instituições a aplicarem as legislações mais progressistas, além de se articularem diante da possibilidade de retrocessos. Na verdade, o que acontece nesse âmbito mais institucional depende do poder de articulação das lutas entre classes e grupos.

Por outro lado, as instituições de âmbito internacional, como as internas, distribuem-se em veículos oficiais e marginais (contra-instituições), que se articulam, entre povos oprimidos, a fim de pressionarem o mecanismo perro das outras, em função de reivindicações comuns dos que ficam por fora ou por baixo (LYRA FILHO, 2005, p. 43).

No caso do Movimento de Mulheres Camponesas, há, em específico, a articulação internacional a partir da Via Campesina Internacional, organização que reunia 164 organizações em 73 países até junho de 2013, segundo dados da própria Via Campesina ${ }^{81}$.

A ideia da criação de um grande movimento que reuniria camponesas e camponeses de todas as partes do mundo, nasceu em 1992, durante o Congreso de la Unión Nacional de Agricultores y de Ganaderos (UNAG), em Manágua, Nicarágua. Em 1993, a então batizada Via Campesina faria a primeira de suas reuniões ${ }^{82}$.

A Via, a partir da articulação de "organizaciones campesinas, pequeños y medianos productores, mujeres rurales, comunidades indígenas, gente sin tierra, jóvenes rurales y

punitiva do Estado, restando completamente impune. Foi reconhecida a responsabilidade do governo brasileiro e recomendada que fosse dada uma resposta ao caso específico e, além disso, que medidas mais intensas de enfrentamento à violência, como a edição de uma legis lação específica (compromis so este as sumido na Convenção de Belém do Pará), fossem realizadas. Fonte: CIDH-OEA. Relatório anual 2000. Relatório $\mathrm{n}^{\circ}$ 54/01, caso 12.051, Maria da Penha Maia Fernandes. Brasil, 4 de abril de 2001. Decisão disponível em: <http://www.sbdp.org.br/arquivos/material/299_Relat\%20n.pdf >. Acesso em: 19 mar. 2015.

81 Informação disponível em: <http://viacampesina.org/es/index.php/organizaciainmenu-44/los-mie mbros mainmenu-71>. Acesso em: 19 mar. 2015.

${ }^{82}$ Segundo dados do sítio na internet da Via Campesina: "En mayo de 1993 se llevó a cabo la primera conferencia de La Vía Campesina en Mons, Bélgica, en donde fue constituida como una Organización Mundial, siendo definidas sus primeras pautas estratégicas y su estructura. La Segunda Conferencia Internacional tuvo lugar en Tlaxcala, México, en abril de 1996, donde asistieron 37 países y 69 organizaciones para analizar una serie de temáticas que eran de preocupación central para los pequeños y medianos productores, a citar: sobera nía alimentaria, reforma agraria, créditos y deuda externa, tecnología, participación de las mujeres y desarrollo rural entre otros". Acesso em: 13 de dez. de 2014. 
rabajadores agrícolas migrantes" ${ }^{, 83}$, tem como pautas a soberania alimentar dos $\operatorname{povos}^{84}$, um modelo camponês de produção de alimentos saudáveis ${ }^{85}$, a descentralização da produção de alimentos e das cadeias de distribuição.

A nível internacional, a Via Campesina destaca-se em relação às lutas contra os transgênicos e o modelo do agronegócio. Suas ações repercutem em ações locais e mesmo são provocadas por elas, em forma de focos de resistência contra o modelo, de forma dialética.

Antes de tecer a crítica, entretanto, é importante destacar alguns pontos de como o capitalismo tem se organizado a nível internacional no campo, tema que retomaremos mais à frente quando trataremos da conformação de forças internas no Brasil e no modo de produção dominante no campo no país.

Há dois modelos que têm sido propostos para a agricultura: um deles é o agronegócio e, o outro, a agricultura camponesa (CONTE, 2011b, p. 18-25). Os dois são desenhados em articulação global/local, com enfoques, práticas e concepções bem diferenciados.

O agronegócio fundamenta-se na grande produção de monoculturas a nível internacional ou nacional, alimentando a chamada agroindústria. Para seu funcionamento, é necessário, portanto, que grandes extensões de terra sejam utilizadas para a produção de um único produto. É necessário, também, uma considerável articulação de transportes para que os produtos sejam distribuídos entre as regiões e países. Há o controle pelo mercado, a partir de grandes empresas, dos produtos desde sua origem, ou melhor dizendo, desde as sementes que serão utilizadas e como a produção será feita. O que tem representado na utilização de sementes transgênicas (geneticamente modificadas) e na utilização de defensivos ou agrotóxicos (para

83 “¿Quién somos? ¿Que es La Vía Campesina ?” Disponível em: <http://viacampesina.org/es/index.php/organizaciainmenu-44/iquisomos-main menu-45?start=2>. Acesso em: 20 mar. 2015.

84 "La soberanía alimentaria es el derecho de los pueblos a alimentos sanos y culturalmente adecuados, producidos mediante métodos sostenibles, así como su derecho a definir sus propios sistemas agrícolas y alimentarios. Desarrolla un modelo de producción campesina sostenible que favorece a las comunidades y su medio ambiente. Sitúa las aspiraciones, necesidades y formas de vida de aquellos que producen, distribuyen y consumen los alimentos en el centro de los sistemas alimentarios y de las políticas alimentarias, por delante de las demandas de mercados y empresas. La soberanía alimentaria da prioridad a la producción y consumo local de alimentos. Proporciona a un país el derecho de proteger a sus productores locales de las importaciones baratas y controlar la producción. Garantiza que los derechos de uso y gestión de tierras, territorios, agua, semillas, ganado y biodiversidad estén en manos de quien produce alimentos y no del sector empresarial. Así, la implementación de una auténtica reforma agraria constituye una de las prioridades del movimiento campesino". Fonte: $<$ http://viacampesina.org/es/index.php/organizaciainmenu-44/iquis omos -main menu-45? limitstart=0>.Aces so em: 21 mar. 2015.

$85 \mathrm{O}$ que coloca o movimento como contrário à utilização de agrotóxicos, sementes transgênicas e a cultura do agronegócio. Essa ação vem em articulação à defesa da soberania alimentar dos povos. 
combate das pragas que atingem as plantações), dentre outras questões relativas a relações trabalhistas e utilização de recursos naturais.

Segundo CONTE (2011b, p. 19):

A agricultura do agronegócio se apropria de grandes quantidades de terra, dos recursos naturais, explora o trabalho humano e é baseado na monocultura, inclusive para exportação (desde cana, café, soja, frutíferas irrigadas, eucalipto...), com pouca diversidade, onde grandes empresas - as Multinacionais ou as Transnacionais - controlam toda a produção e comercialização das sementes. O Agronegócio é um modelo de agricultura que se utiliza de grande quantidade de venenos, fertilizantes, pesticidas, etc., destruindo e contaminando a natureza.

Para o agronegócio, a produção, processamento e repasse de alimentos para população é um negócio. O alimento, desde as suas sementes até seu "beneficiamento" pela indústria, é uma mercadoria. A forma de produzir e comercializar deve versar sempre pela diminuição de custos e maximização de lucros para as empresas e os produtores do agronegócio.

No Agronegócio, as grandes Multinacionais e Transnacionais, ditam as regras do mercado, (a produção para exportação, qual monocultura deve ser plantada, o que vai ser comprado, com que preço, quanto veneno vai ser usado). Assim, definem e ditam o que a população deve comer, porque elas que colocam os produtos no mercado e fazem a propaganda sobre os produtos que pretendem vender.

(...)

No Agronegócio os ALIMENTOS são transformados em commodities. Comodity, em inglês, quer dizer mercadoria, então, o alimento não é mais alimento, é uma Mercadoria. Como uma mercadoria o alimento passa a seguir as regras do mercado: produção em grande quantidade e padronizados, mudam a cor, o formato/tamanho, gosto, o jeito de plantar e colher... (CONTE, 2011b, p. 20) (com grifo no original).

As organizações pertencentes à Via Campesina, pois, acusam que se tem produzido e comido alimentos que fazem mal à saúde da população para beneficiar grandes empresas que dominam a técnica da produção de sementes transgênicas, manipulação que, em tese, aumenta sua produtividade, mas que tende a eliminar as espécies não transgênicas, acabando com a diversidade natural. 
Outro dado importante é que não se conhecem os efeitos sobre a saúde do consumo de transgênicos e há mesmo a suspeita de que sua utilização, combinada a outros químicos, como os agrotóxicos, podem estar ligados ao aumento de casos de câncer e outras enfermidades. Há países que, vislumbrando o risco para a saúde, já proibiram em seus territórios a utilização de sementes transgênicas ${ }^{86}$.

Essas plantas transgênicas, segundo a Via Campesina e o Movimento de Mulheres Camponesas, sustentados por pesquisas científicas, podem fazer mal à saúde ${ }^{87}$. Por outro lado, exigem a utilização de agrotóxicos poderosos, também produzidos pelas mesmas empresas multinacionais. Enquanto elas lucram, há todo um prejúzo que atinge a população e, dentro dela, mais duramente, os grupos e classes sociais mais frágeis.

Acerca de ação recente contra o modelo acima colocado, na Empresa Bunge, no último dia 9 de março de 2015, o próprio Movimento de Mulheres Camponesas afirma:

A Empresa Bunge está entre as 10 grandes empresas que controlam a produção e comercialização de sementes e insumos agrícolas, baseada nos transgênicos, nos agrotóxicos e nos adubos sintéticos. Esse modelo de produção causa destruição da biodiversidade, contamina o solo, água, ar, provoca doenças e morte das pessoas, causa perda da soberania alimentar e nacional, concentra terra e expulsa camponesas e camponeses do campo, impacta diretamente e violenta a vida das mulheres.

As mulheres mobilizadas dizem não a esse modelo do agronegócio. Denunciam todas as formas de violência contra as mulheres, são contra o modelo Capitalista e Patriarcal.

Lutam por um Projeto de Agricultura Camponesa agroecológica, produzindo alimentos saudáveis, cuidando da vida e do ambiente ${ }^{88}$.

86 Países como a França, Itália, Rússia, China, além de outros países. Notícias disponíveis em: $<$ http://exame.abril.com.br/mundo/noticias/franca-proibe-definitivamente-milho-trans genico-da-monsanto>; $<$ http://www.mst.org.br/node/16022; http://jornalggn.com.br/noticia/a-proibicao-dos-transgenicos-na-russia-pormauro-santayana>; <http://www.ihu.unisinos.br/noticias/530361-proibicao-da-china-a-milho-dos-eua-esquentadebate-sobre-transgenicos>; <http://altamiroborges.blogspot.com.br/2011/02/produtos -trans genicos-agonizamna.html>. Acessos em: 4 out. 2014.

87 "Embora suas propriedades nutricionais sejam mantidas, (...) o estudo francês revelou que os grãos do milho trans gênico apontam claros sinais de toxidade. O biólogo molecular Gilles-Eric Séralini e sua equipe puderam divulgar a pesquis a depois que uma decisão judicial obrigou a Monsanto revelar sua própria análise dos grãos que manteve em sigilo impedindo que a informação se tornasse pública". Artigo "Monsanto revela que milho transgênico pode fazer mal à saúde", de 28 de abril de 2014. Disponível em: <http://www.revistaecologica.com/monsanto-revela-que-milho-transgenico-pode-fazer-mal-saude/>. Acesso em: 20 mar. 2015.

${ }^{88}$ Notícia publicada no sítio do MMC. "Mulheres camponesas ocupam Bunge e denunciam o Agronegócio". A ação na Empresa fez parte de uma série de ações da Jornada Nacional de Luta das Mulheres Trabalhadoras do 
A crítica lançada pelos movimentos articulados na Via Campesina, de uma forma resumida, é contra o modo de produção capitalista no campo. Defendem o socialismo como estrutura e o modo específico de plantar de acordo com os princípios agroecológicos, que vão além do modo de agricultura camponesa tradicional, que ainda se encerra no modo patriarcal de produção no campo, atribuindo mais valor às atividades executadas pelos homens.

No que diz respeito às camponesas, a Via Campesina, a partir da luta das mulheres que a integram ${ }^{89}$, pauta a importância de se discutir também a cultura camponesa no que diz respeito à já discutida divisão sexual do trabalho no campo e às violências decorrentes das relações sociais de sexo.

As mulheres da Via, articuladas, inscreveram instrumentos de garantia de participação igualitária na gestão da organização, como o de determinar que as coordenações (são nove regionais internacionais) sejam compostas de um homem e uma mulher. Colocaram a paridade de gênero entre os temas principais da Via e, dentre as estratégias da organização, está o fortalecimento da participação das mulheres em matérias sociais, econômicas, políticas e culturais.

Em seus documentos, manifesta, claramente, uma posição que reflete o entendime nto das lideranças do MMC sobre a relação entre capitalismo e patriarcado e a compreensão acerca da importância das mulheres para a produção de alimentos:

Las mujeres juegan un papel fundamental en el trabajo de La Vía Campesina. Según la FAO, las mujeres producen el $70 \%$ de los alimentos mundiales pero están marginadas y oprimidas por el neoliberalismo y el patriarcado. El movimiento defiende los derechos de las mujeres y la igualdad de género a todos los niveles y lucha contra todas las formas de violencia hacia las mujeres $^{90}$.

\footnotetext{
Campo e da Cidade, de 8 a 15 de março de 2015, com o lema "Por Soberania Alimentar, contra a Violência e o Agronegócio". Disponível em <http://www.mmcbrasil.com.br/site/node/246>. Acesso em: 21 mar. 2015.

${ }^{89}$ Não aprofundamos, durante a pesquisa de campo, como se deram e se dão as disputas políticas dentro da Via contra as relações sociais de sexo. Percebemos, no entanto, ocasionalmente, durante a observação participante, que a intensa participação de mulheres na Via não é destituída de tensões com a repetição de posicionamentos machistas pelos homens, e algumas mulheres quando negam ou silenciam diante de uma postura machista de homens lideranças dos movimentos de camponeses.

90 Disponível em: <http://viacampesina.org/es/index.php/organizaciainmenu-44/iquis omos-main menu-45/1108la-voz-de-las-campesinas-y-de-los-campesinos-del-mundo>. Acesso em: 21 mar. 2015.
} 
A Via Campesina tem também uma cartilha específica acerca do enfrentamento à violência contra as mulheres: "Os camponeses e as camponesas da Via Campesina dizem: Basta de violência contra as mulheres", que encara de forma articulada a violência doméstica e familiar, a divisão sexual do trabalho e o modo de produção capitalista no campo.

Compreendendo o quão são articuladas as questões internacionais e locais, e o quanto o modo de produção pode influenciar nas decisões de Estado, o MMC não somente assume pautas específicas à produção de alimentos no campo, pela Via Campesina, como também apoia declaradamente e diretamente governos que se alinham com um padrão socialista, como Cuba ${ }^{91}$ e Venezuela ${ }^{92}$, e/ou com as causas camponesas, como o governo de Evo Morales, na Bolívia, que recolocou a posição dos indígenas dentro do Estado.

Entendem que a mudança do modo de produção a nível internacional é fundamental para a melhoria das condições de vida dos camponeses e das camponesas e mesmo para a própria sobrevivência humana, sendo necessária a transformação global da sociedade, com o estabelecimento de novos valores, operando para o fim das divisões hierárquicas entre classes e grupos sociais.

Resistimos no campo às conseqüências econômicas, políticas, sociais e culturais do projeto capitalista e patriarcal que intensifica a exploração de trabalhadoras e trabalhadores, aumentando a violência e a discriminação contra as mulheres.

Há mais de vinte anos construímos um Movimento autônomo, democrático, popular, feminista e de classe, na perspectiva socialista. ${ }^{93}$

\footnotetext{
${ }^{91}$ Por intermédio da Via Campesina, o MMC tem enviado sua militância para a realização de cursos superiores, como a Medicina na Escola Latinoamericana de Medicina de Cuba (ELAM). A ação visa formar médicas e médicos que tenham compromisso com as causas populares e retornem a seus países para trabalhar com o povo. Ver: "Jovens camponesas formadas Médicas em Cuba debatem saúde da mulher com jovens do MMC", disponível em: 〈http://www.mmcbrasil.com.br/site/node/236>. Acesso em: 21 mar. 2015.

${ }^{92}$ O MMC, por exemplo, lançou carta de apoio ao povo venezuelano em razão da morte de Hugo Chávez. Na carta, mencionam que Chávez lutou não só pelos interesses de seu país, mas atuou de forma articulada para a garantia de uma América Latina livre do imperialismo. Ver: 〈http://www.mmcbrasil.com.br/site/node/73〉. Acesso em: 18 dez. de 2014.

93 "Quem somos", disponível no sítio do MMC na internet: <http://www.mmcbrasil.co m.br/site/node/43>. Acesso em: 21 mar. 2015.
} 
No dizer de Lyra, "dentro deste panorama é que surgem as sociedades individualmente consideradas e sujeitas à penetrante interferência do sistema externo". Vamos pensar um pouco nessa assertiva discorrendo sobre a conformação de forças no país.

Mas, antes disso, adiantamos que também na perspectiva nacional há duplos movimentos que se conjugam e entram em conflito, de forma dialética. Há um poder instituído e uma classe e grupos dominantes, que garantem coesão ao sistema (o que Lyra nomeará de forças centrípedas) e há um (ou vários) contra-poder(es), ou forças centrífugas, que disputam a transformação da sociedade. Essas lutas culminam na reforma do que está posto e/ou em tentativas (ainda não concluídas) de transformação do modo de produção articuladas (ou não) à transformação de usos, costumes, mores e folkwares dominantes.

Sobre a dupla base interpenetrante das infra-estruturas internacional e nacional é que se armam os aspectos derivados e superestruturais - de um lado, estabelecendo a coesão, e, de outro, a dispersão. Se uma sociedade não tivesse o mínimo de força centrípeta para garantir e própria coesão explodiria como bola de borracha, soprada pela anarquia; se, por outro lado, não revelasse um coeficiente de forças centrífugas seria (como, iludidos, sempre esperam os donos do poder) uma estrutura inalterável e eternamente impeditiva de qualquer mudança verdadeira (LYRA FILHO, 2005, p. 44).

\subsubsection{Lutas de Classes e Grupos no Campo Brasileiro}

Passemos, então, a analisar de forma sucinta as forças a nível nacional no que diz respeito à questão agrária, de modo geral, e as mulheres e o Movimento de Mulheres Camponesas em meio a esse caldo: em primeiro passo, as forças conservadoras e a constituição do modelo hegemônico no campo, ou as forças centrípedas, no dizer de Lyra Filho; em segundo lugar, analisaremos a organização das forças centrífugas, que geram o questionamento e as resistências com possibilidades à reorganização das forças e, consequentemente, transformações. Após esse esforço, vamos descrever as leis e políticas existentes no combate à violência contra a mulher camponesa e algumas críticas realizadas pelo MMC.

As seguintes linhas são fundamentadas nas obras organizadas por/de Mary Del Priore (2010), João Pedro Stedile (2006), nos documentos e textos do Movimento de Mulheres Camponesas e outros movimentos do campo, na observação participante, quando o tema entrava em pauta nas reuniões e falas do MMC. 


\section{A) Forças centrípedas no Campo Brasileiro e as Questões das Camponesas}

O Brasil que conhecemos hoje, sua estruturação em classes e grupos sociais, seu modo de produção e o aparato cultural que se articulou de forma complexa por e para a sustentação do modo de produção e outras relações de poder, foram conformados a partir do relacioname nto estreito com a organização de forças e instituições a nível internacional.

Voltemos à história da conquista do território de forma sucinta e de algumas questões que foram fundamentais para a conformação de dominações e resistências, no que diz respeito à questão agrária e às relações sociais de sexo.

De forma não exaustiva, citamos as questões gerais relacionadas à conformação de forças no campo: a tomada de terra dos indígenas, a decisão de ter no Brasil uma colônia agrícola para abastecimento da Europa ${ }^{94}$; a tentativa fracassada de utilizar os indígenas como mão de obra (diante das interferências da Igreja, do fracasso com os Tupinambás e outros grupos e da perspectiva mais lucrativa com o comércio de escravos africanos); a utilização de mão de obra escrava africana e a abolição sem distribuição de terra e renda; a chegada dos imigrantes europeus para o início do trabalho assalariado no Brasil; a produção do campo no Brasil fundada em grandes propriedades concentradas nas mãos de poucos homens brancos e europeus, desde a divisão do Brasil em Capitanias Hereditárias (e que depois viriam a ser assumidos pelos seus descendentes brasileiros, também homens e brancos), destinadas à monocultura e voltadas para as demandas e necessidades do mercado externo, primeiro europeu e depois mesmo mundial.

Uma conformação estreita entre patriarcado, racismo e capitalismo, com o apoio inicial da Igreja Católica (e posteriormente das igrejas protestantes pentecostais ${ }^{95}$ ), gerou uma

\footnotetext{
94 "Coube a Portugal a tarefa de encontrar uma forma de utilização econômica das terras americanas que não fosse a fácil extração de metais preciosos. Somente assim seria possível cobrir os gastos de defesa dessas terras. (...) Das medidas políticas que então foram tomadas, resultou o início da exploração agrícola das terras brasileiras, acontecimento de enorme importância na história americana. De simples empresa espoliativa e extrativista idêntica à que na mesma época estava sendo empreendida na costa da África e nas Índias Orientais - a América passa a constituir parte integrante da economia reprodutiva européia, cuja técnicas e capitais nela se aplicam para criar de forma permanente um fluxo de bens destinado ao mercado europeu” (FURTADO, 1989, p. 8).

95 Os evangélicos reúnem-se na chamada Frente Parlamentar da Família e Apoio à Vida, com pessoas que nomeadamente se elegeram com a plataforma ou a ela acabaram se unindo por convicções religiosas. Sobre a composição do Congresso atual, ler: "Composição da Bancada Evangélica de 2015 a 2019”, disponível em: $<\mathrm{http} / / /$ www.eleicoeshoje.com.br/composicao-da-bancada-evangelica-de-2015-2019/> e "Bancada evangélica terá 74 deputados em 2015”, disponível em:
} <http://www2.camara.leg.br/ca maranoticias/radio/materias/ELEICOES -2014/476128-BA NCADAEVANGELICA-TERA-74-DEPUTADOS-EM-2015.html>. Acessos em: 21 mar. 2015. 
poderosa elite branca e masculina no campo que estendeu seus tentáculos para a política local, estadual e nacional com a presença de coronéis em cargos eletivos a partir, inicialmente, de "voto de cabresto", combinada a práticas clientelistas que ainda hoje sobrevivem (CARVALHO, 2002).

Não podemos nos esquecer da importância da experimentação de uma ditadura militar, apoiada pelo imperialismo norte-americano a nível internacional, como forma de coibir o avanço do socialismo para a América Latina, e por elites retrógadas (com um pé no campo) a nível nacional que continuam mantendo o poder, modernizando-se somente até o ponto que lhes interessasse (IANNI, 1979).

Naquela época, encontrou um grau de relevância internacional uma articulação camponesa organizada a partir do Nordeste brasileiro: as Ligas Camponesas, tendo como seu principal articulador o camponês pernambucano Francisco Julião. A ela retornaremos.

Os Estados Unidos enviaram um representante que, visitando o Nordeste do Brasil, percebeu que aquele poderia ser um barril de pólvora para uma revolução no Brasil, que deveria ser sufocada o mais rápido possível:

Juntamente com um grupo de integrantes do governo estadounidense, ciceroneado pelo superintendente da Sudene, Celso Furtado, ele [o escritor Arthur Schlesinger Jr.] passou nove horas viajando pelo interior. Em um vilarejo, um menino de cerca de dois anos, completamente nu, disparou na direção deles. A cena, conforme vista por Schlesinger: "(ele) correu alegremente para nós, estendendo os braços para que o pegássemos no colo. Estava coberto de feridas e marcas de sarampo. Não tivemos coragem de tocar nele."

Pela contundência do relato e pelo respeito que Kennedy tinha por Schlesinger (hoje um dos principais intelectuais dos EUA), a descrição do que ele vira teve influência também sobre o presidente. A China havia feito uma revolução em 1949 e Cuba, em 1959 - ambas com a participação maciça de camponeses. O cenário aqui tinha ingredientes preocupantes, na visão estadounidense: miséria e camponeses revoltados. Em $1^{\circ}$ de novembro de 1960, o The New York Times bradava em manchete: "Marxistas estão organizando os camponeses no Brasil". No dia anterior, em matéria com chamada de primeira página, o tom fora o mesmo: "O surgimento de uma situação revolucionária é cada vez mais nítido" no Nordeste. Em ambas, o foco era a atuação das Ligas Camponesas. Fidel Castro e Mao Tse-tung, afirmavam as reportagens, assinadas por Tad Szulc, estavam sendo apresentados como heróis para os camponeses, estudantes e trabalhadores urbanos (ANDRADES; GANIMI, 2007). 
Com o apoio do Estado militarizado e a máxima do "Brasil Grande" e do "mila gre brasileiro", as elites agrárias fortaleceram-se no Nordeste do país (a partir da SUDENE) e ocuparam o Norte (a partir da SUDAM) (MENEZES, 2007). Um também grande contingente populacional foi conclamado para ocupar áreas "sem homens" na Amazônia.

Os trabalhadores que migraram, principalmente do Nordeste, com a esperança de garantir melhores condições de vida, foram superexplorados nas madeireiras e na "abertura de floresta" para criação de gado, sendo que alguns desses trabalhadores sofreram mesmo com o que seria conhecida anos depois como a "escravidão moderna", trabalho forçado para pagamento de dívidas "criadas" pelo próprio patrão. As terras foram cada vez mais se concentrando nas mãos de poucos proprietários com a justificativa de desenvolvimento do Brasil (IANNI, 1979).

Muito dinheiro foi emprestado e muita terra concedida para o "desenvolvimento". Muitos projetos falharam e terras cedidas do Estado Brasileiro com fins específicos foram irregularmente revendidas e griladas. Por sua vez, a população que havia se deslocado, por lá ficou, ocupando terras e lutando pela própria sobrevivência.

Seriam compelidos a sair anos mais tarde a partir da expansão das fronteiras agrícolas, principalmente de soja, ou para a instalação de grandes projetos, como as hidrelétricas e mesmo a Estrada de Ferro Carajás. Boa parte dos conflitos no campo na Amazônia surgem a partir dessa estruturação da divisão de terras e incentivos governamentais baseados no modelo groexportador (CASTRO; MOURA; MAIA, 1995) ${ }^{96}$.

Mesmo com a abertura democrática, essas forças se rearticularam e se mantiveram no poder.

Lembremos que o capitalismo a nível internacional, na década de 1980, momento em que as ditaduras na América Latina não conseguiam mais se manter, tinha obtido uma grande vitória contra seu maior adversário até então. Em 1989, com a Queda do Muro de Berlim, vivenciou-se uma propagação de derrota do chamado socialismo real, e se vendeu a ideia de que o capitalismo, agora em sua versão financeira, era o único modo de produção possível (SANTOS, 2013).

\footnotetext{
96 As referências aqui colocadas sobre a situação da Amazônia vêm também a partir de trabalho na cidade de Anapu/Altamira, no Estado do Pará, como advogada da Comissão Pastoral da Terra, em uma experiência com os conflitos agrários e atendimento a pessoas em situação de trabalho escravo.
} 
No Brasil, uma transição lenta, gradual e "pacífica" para a democracia garantiu a possibilidade de manutenção da elite criada no campo, articulada com empresas multinacionais que, a partir da Revolução Verde ${ }^{97}$, passaram não só a controlar o que deveria ser produzido e comercializado, mas como isso seria feito, a partir de sementes e insumos (como agrotóxicos), tudo isso com apoio direto do governo brasileiro que fez a opção nessa época pela Revolução Verde em lugar de promover a reivindicada reforma agrária.

A concepção de uma agricultura como agronegócio continuou a repercutir sobre a forma como os governos, dentro eles o do Brasil, comportam-se quando o assunto é o fomento à produção de alimentos, de forma que o que se vislumbra é a integração ao mercado exportador a partir desse paradigma.

Mesmo a agricultura familiar é estimulada pelo governo a uma integração, com o apoio financeiro, claro que cobrado depois a juros, para a aquisição de tecnologia de uso de sementes transgênicas e agrotóxicos, destinado à produção de monocultura para o mercado, ao lado de uma pequena produção mais diversificada somente para consumo familiar.

Esses empreendimentos foram chamados de "agronegocinhos" e a crítica da agricultura agroecológica é dura, nesse sentido:

Segundo Zaré Brum, representante da Contag, (...) há um claro direcionamento das políticas públicas para o agronegócio. "Há uma disputa muito grande hoje dentro da academia e do governo e que vem contaminando inclusive os próprios movimentos sociais de um discurso negando a especificidade da agricultura familiar em relação à agricultura industrial. Esse discurso está pautando a elaboração de políticas que acreditam que o desenvolvimento da agricultura familiar pode se dar através de um padrão tecnológico próximo ao do agronegócio e que a única diferença entre os dois modelos seria a escala de produção. Muitas políticas vêm se pautado para o que chamam de agronegocinho", diz. ${ }^{98}$

\footnotetext{
97 A chamada Revolução Verde foi a resposta dos Estados Unidos e grandes multinacionais após a Segunda Guerra para o enfrentamento à fome no mundo. Com a promessa de aumento da produtividade, grandes empresas destinaram seus esforços e pers pectivas de lucros para o mercado de alimentos, a partir dos OGMs, organismos geneticamente modificados, aprimoramento de insumos como agrotóxicos, fertilizantes e adubos químicos, além de grande maquinário. Ver: ANDRADES, Thiago Oliveira de; GANIMI, Rosângela Nasser. Revolução verde e a apropriação capitalista. CES Revista online, Centro de Ensino Superior de Juiz de Fora. Edição 2007. Disponível em: <http://www.cesjf.br/revistas/cesrevista/edicoes/2007/revolucao_verde.pdf>. Acesso: 11 dez. 2014.

98 Reportagem “Agricultores familiares não querem ser 'agronegocinho"”, por Raquel Júnia. Disponível em: $<$ http://www.agroecologia.org.br/index.php/noticias/224-agricultores-fa miliares-nao-querem-seragronegocinho>. Acesso em: 10 dez. 2014
} 
O modelo do agronegócio a nível nacional também favorece o poder econômico e político de uma elite ruralista que impede ou desmerece a importância, por exemplo, da realização da reforma agrária no Brasil. ${ }^{99}$

Com um quadro que fortalece uma elite cada vez mais restrita, deixando à margem uma grande população negra (ou quase negra) e de camponeses brancos e pobres, no sul do país, como manter um regime desses como dominante?

Quem se encarrega disso, usando a terminologia apresentada por Lyra Filho, são os usos, costumes, folkwares e mores dominantes, a partir de suas instituições, com o uso sempre presente, em todos os momentos da história, do direito estatal e suas forças repressivas.

Foram construídas sólidas ideias no imaginário popular que fomentaram uma resistência contra um regime que não fosse o capitalista, ou uma agricultura que não fosse a do agronegócio, no nosso caso em específico. O modo de ver e entender o mundo seriam também dominadas por visões racistas e sexistas (em um nó com o capitalismo, como diria Kergoat).

Foi plantada também uma repulsa contra as formas de resistência e organização social. Criminosos, desordeiros, bruxas, vadias, vagabundos, contrários à moral e aos bons costumes, satânicos...

Um poderoso aparato de comunicação, que envolve imprensa escrita, falada e televisionada (agora com o apoio mais recente das redes sociais para disseminação de um discurso de ódio), no caso do campo, operou para dar sustentação ao discurso de que o agronegócio é o progresso, silenciou quanto às críticas à Revolução Verde e o apelo a uma produção agroecológica e contribuiu para disseminar a ideia de criminalização dos movimentos de luta no campo (GUISOLPHI, 2010; ESCRIVÃO FILHO, 2010).

De outro lado, as dificuldades legais para o reconhecimento da posse de comunidades tradicionais, quilombolas e indígenas; a garantia de reintegração de posse de grileiros fundada em títulos de propriedade fraudulentos; a vista grossa acerca da ação de milícias armadas de fazendeiros no campo contra posseiros; a criminalização de ações de resistência e de ocupação de terras como ação política para realização de reforma agrária; e o sentimento de impunidade que tem restado diante de assassinatos de lideranças populares no campo; têm sido a tônica que

\footnotetext{
${ }^{99}$ Ver reportagem: "Não existe mais latifúndio no Brasil, diz nova ministra da Agricultura", por Mônica Bérgamo. Entrevista de Kátia Abreu para o jornal Folha de $S$. Paulo. Disponível em: <http://www1.folha.uol.com.br/poder/2015/01/1570557-nao-existe-mais-latifundio-no-brasil-d iz-nova-min is trada-agricultura.shtml>. Acesso em: 22 mar. 2015.
} 
tem preponderado nas ações do Estado, por meio de suas forças de segurança, no que diz respeito aos conflitos no campo e à interpretação e aplicação do direito estatal pelas instituições dominantes. ${ }^{100}$

Essas e outras questões fizeram do modelo do agronegócio o modo de produção preponderante no Brasil, um país que nasce situado na periferia do sistema, sustentado localmente por vozes conservadoras e reacionárias, que se consubstanciaram em usos, costumes, folkways e mores dominantes, que tiveram (e ainda têm) nas relações sociais de sexo e no racismo os pontos determinantes para hierarquizações em relação às classes sociais, como exporemos a seguir, embora, ideologicamente, tenha sido construída a falsa ideia de igualdade de oportunidades e de que vivemos em uma "democracia ou paraíso racial" (GUIMARAES, 2003).

O que significou essa cultura dominante, de modo específico, para as mulheres camponesas?

Significou que a divisão sexual do trabalho no campo se entrelaçaria de forma muito estreita com o mercado capitalista. As relações desiguais de poder articuladas sob a égide do patriarcado, repercutiria de uma forma muito "especial" sobre as mulheres quanto a limitações de possibilidades da construção da própria autonomia econômica, política e social.

A construção dessa articulação no Brasil tem relação direta com os fatos que descrevemos no início deste tópico em relação à construção de uma classe dominante agrária. $\mathrm{O}$ que não destacamos, naquele momento generalista, foi a circunstância de que essa classe dominante tem sexo e tem cor e que, mesmo dentre as classes populares, homens e mulheres têm posições diferenciadas.

Nesse ínterim, de modo geral, também, citaremos algumas questões relevantes para a conformação das relações sociais de sexo no campo, fazendo uma reconstrução a partir do exemplo das mulheres do Sul e Sudeste, composição realizada principalmente a partir do colonato europeu que se configurou como primeira classe com trabalho assalariado no Brasil, após a abolição da escravatura. O contexto não foi escolhido a esmo, mas a partir da

\footnotetext{
100 Desde 1985, os conflitos no campo que repercutem ano a ano todas as questões levantadas acima são relatados pela Comissão Pastoral da Terra em uma série de publicações que podem ser conferidas no sítio: <http://www.cptnacional.org.br/index.php/publicacoes/conflitos -no-campo-brasil>. Acesso em: 13 abr. 2014.
} 
consideração de que o Movimento de Mulheres Camponesas tem origem no Sul do país, conforme veremos. ${ }^{101}$

Primeiramente, é importante destacar que, desde o Brasil Colônia, houve uma tentativa moralizadora em geral, onde quer que houvesse a imprensa escrita e a Igreja Católica.

De forma indiscriminada, queria se atingir mulheres pobres e ricas, brancas ou mestiças, quanto à necessidade da construção de uma feminilidade calcada na ideia da "mãe", que seria seu destino natural. A outra "opção" para as mulheres seria ser "freira" ou "puta" (PRIORE, 1993).

A Igreja vislumbrava moralizar as relações conjugais no Brasil que, naquela época colonial, entre brancos e negras/índígenas e entre os próprios negros e indígenas e os mestiços, a regra era o não matrimônio.

Nem maternidades ideais, nem a Terra de Santa Cruz o paraíso terreal; o que se assistiu, ao longo dos primeiros séculos de colonização, foi a obstinada imposição por parte da Igreja da instituição do matrimônio, através do adestramento crescente de tantas mulheres na figura de mãe. Mãe esta que não devia colocar seu ventre a serviço de muitos homens, nem confundir a prole legítima com os bastardos de seu marido, devia, sim, conformar-se com o desejo que tinham a Igreja e o Estado para o seu corpo, fugindo da tradição do amasiamento legada pelas relações entre brancos e índias, bem como da tradição do concubinato, trazida pelos portugueses e amplamente difundida entre as classes subalternas (PRIORE, 1993, p. 105).

No século XIX, amparado pelo discurso científico, houve ainda um esforço dos mesmos expedientes para fortalecer mais características ligadas à mulher: docilidade, recato, comedidade e com elas as responsabilidades de cuidado dos filhos, do marido, a guardiã do lar.

\footnotetext{
101 Para situar o contexto de construção da categoria das camponesas trabalharemos, pois, de forma emblemática com a história de mulheres de origem europeia. Boa parte de colonas de antigamente e boias frias de hoje. Não negamos aqui o caráter nacional do movimento e a importância das regiões Nordeste, Norte e Centro -Oeste na sua composição. A escolha de busca de uma história inicial das camponesas no Brasil quer dizer que não mencionaremos com mais vagar as tentativas de conformação de indígenas e grupos étnicos, como as quilombolas, que integram o conceito de camponesas, como já vimos. Presenciamos, no período da observação participante, principalmente no que diz respeito ao Encontro Nacional do Movimento de Mulheres Campone sas, em fevereiro de 2014, a presença de mulheres do Norte do país, em especial de indígenas; de mulheres do litoral, como pescadoras e ribeirinhas; de quebradeiras de coco babaçu; de quilombolas; dentre um universo que merecia, cada qual, um detalhamento mais pormenorizado a fim de que se percebesse a riqueza e multiplicidade de visões de mundo dentro do movimento.
} 
A mulher deveria estar reservada ao lar e, quando estivesse na rua, deveria ter modos que correspondessem ao seu estado natural e deveria estar sempre acompanhada.

As imposições da nova ordem tinham o respaldo da ciência, o paradigma do momento. A medicina social assegurava como características femininas, por razões biológicas: a fragilidade, o recato, o predomínio das faculdades afetivas sobre as intelectuais, a subordinação da sexualidade à vocação maternal. Em oposição, o homem conjugava à sua força física uma natureza autoritária, empreendedora, racional e uma sexualidade sem freios. As características atribuídas às mulheres eram suficientes para justificar que se exigisse delas uma atitude de submissão, um comportamento que não maculasse sua honra. Estavam impedidas do exercício da sexualidade antes de se casarem e, depois, deviam restringi-la ao âmbito desse casamento (SOIHET, 2010, p. 363).

Embora não tenha conseguido impor essa imagem para as mulheres pobres, que precisavam sair de casa para ganhar a vida trabalhando e tinham, na rua, o seu espaço de relações sociais, de fato, conseguiu estabelecer no Brasil a ideia de que as crianças são de responsabilidade das mulheres.

As atividades das mulheres populares desdobravam-se em sua própria maneira de pensar e de viver, contribuindo para que procedessem de forma menos inibida que as de outra classe social, o que se configurava através de um linguajar "mais solto", maior liberdade de locomoção e iniciativa das decisões. Seus ganhos estavam na última escala, já que persistia a ideologia dominante de que "a mulher trabalha apenas para seus botões", desdobramento das concepções relativas à inferioridade feminina, incapaz de competir em situação de igualdade com os homens. E, apesar de todas as precariedades de seu cotidiano, assumiam a responsabilidade integral pelos filhos, pois "maternidade era assunto de mulher" (SOIHET, 2010, p. 367).

(...) O cuidado das crianças cabia, conforme os ditados da divisão tradicional do trabalho, à mulher, porém, essa mulher não era sempre a mãe biológica . Para fazermos considerações sobre a maternidade em grupos populares, temos portanto de levar em consideração também avós, criadeiras e mães de criação (FONSECA, 2010, p. 534-535)

Em relação às mulheres do Sul, as colonas que chegavam para o trabalho no campo e mesmo para a ocupação das cidades, há notícias de que houve também um trabalho que lhes foi especialmente dirigido quanto à construção de uma feminilidade esperada: com elogio a alguns 
comportamentos e mesmo tentativa de desestimular que as mulheres se ocupassem de trabalhos fora de casa, mesmo que relacionados com a própria plantação da família:

Em 1910, o jornal Blumenauer Zeitung apontava as novas exigências para o sexo feminino, atribuindo às mulheres a exclusividade dos trabalhos domésticos e questionando sua participação em atividades agrícolas. Num texto longo, paira a dúvida sobre o rendimento do trabalho feminino na "roça", pois este a retiraria dos seus cuidados de mãe e dona de casa, “... pois eles são a função própria da mulher em qualquer etapa da vida...”. Se a mulher se mantivesse trabalhando na "roça", a família teria "sensíveis prejuízos em dinheiro" devido à perda de forças de seu corpo, ao abandono em que ficariam as crianças e os serviços domésticos (PEDRO, 2010, p. 289).

Apesar do esforço acima, esboçado por parte de uma intelectualidade que ocupava os jornais, uma completa interdição do trabalho produtivo na roça era inviável. Elas já faziam parte do processo produtivo, de forma peculiar, trabalho acumulado com as tarefas que listaremos.

Já desde algumas décadas atrás, com a chegada dos colonos para a substituição da mão de obra escrava, muitas dessas mulheres (e também crianças) pegariam no "cabo da enxada", ao lado dos homens, "chefes" da família, que exerciam sobre o grupo uma posição de mando.

A organização do trabalho - a alocação dos diferentes membros da familia no trabalho - cabia ao homem. Sendo simultaneamente chefe da família e do trabalho, seu poder atingia a todos os membros, transformando filhos e mulher praticamente em seus trabalhadores (SILVA, 2010b, p. 557).

Isso garantia ao homem um simbólico papel de autoridade dentro do núcleo familiar camponês e ultrapassava as relações de trabalho. Dava-lhe, na verdade, poder sobre o destino do grupo:

Como vimos, o chefe da família apresentava-se diante da esposa e dos filhos como a personificação da exigência dos proprietários - como o verdadeiro "patrão", o supervisor e o capataz. O poder masculino centrava-se na figura do pai-marido-patrão. Muitos depoimentos de ex-colonas, mostram que a autoridade do homem poderia ser expressa até no olhar: "Meu pai não precisava falar com a gente, bastava olhar, e a gente sabia o que ele queria ou não." Essa autoridade não dizia respeito apenas ao trabalho. Ela perpassava todo o tecido social, de tal maneira que as mulheres e filhos estavam sujeitos 
a um conjunto de normas e valores sociais que reforçavamo domínio e o poder dos homens (SILVA, 2010b, p. 558).

Isso não as desobrigava de estar acumulando uma série de outras tarefas que the diriam que pertenciam ao seu sexo. Ao contrário de favorecer uma posição de poder em decorrência de sua importância produtiva e reprodutiva, repisemos, seu trabalho era diminuído com a ideia poderosa de que qualquer atividade que executasse nesse prumo, seria de apenas ajuda e acessória à do marido, resta com força até hoje.

dependia da capacidade das mulheres de aproveitarem ao máximo as vantagens desse regime de trabalho, que lhes permitia conjugar o trabalho da casa como da roça e do cafezal. Mas, apesar de desempenharem tarefas dentro da casa, na roça de subsistência e no cafezal, as mulheres não existiam enquanto trabalhadoras individualizadas, porque seus trabalhos eram englobados no trabalho familiar controlado diretamente pelo pai-marido (SILVA, 2010b, p. 557).

As imigrantes europeias eram elogiadas pela seriedade e, a partir delas, desenhado um modelo moral a ser seguido: a exemplo das alemãs, construiu-se a virtude de "trabalhadeira", quando os homens eram chamados de "trabalhadores", garantindo, de um só passo, que a dedicação ao trabalho (explorado) por parte dos homens fosse uma qualificadora e que a virtude das mulheres seria a de fazer inúmeras tarefas em apoio a este homem.

\begin{abstract}
A importância da família para o colono, especialmente ter uma mulher, aparece em inúmeros relatos. A manutenção dos hábitos e dos costumes alemães dependia das mulheres, as quais através das "prendas domésticas", ofereciam um conforto difícil de ser mantido sem a presença feminina. Apesar disso, o que se observa é que somente os homens são considerados responsáveis pelo desenvolvimento da região. A própria representação da imagem das mulheres de origem alemã como "trabalhadeira", diferentemente dos homens considerados "trabalhadores", contribui para a invisibilidade da contribuição feminina (PEDRO, 2010, p. 288-289).
\end{abstract}

De fato, as camponesas garantiriam dentro de casa tudo aquilo que não pudesse ser comprado no mercado: de roupas à alimentação básica da família cultivada em hortas na cercania de suas casas (ou mesmo nos terrenos mais afastados e que não serviam à plantação 
“do homem"); da água, que poderia estar a quilômetros de distância, à criação de pequenos animais para consumo próprio e o cultivo de ervas medicinais para garantia de remédios para a família; além de trabalhar diretamente na plantação "do marido", de sol a sol, embora esse trabalho sempre fosse visto como "ajuda".

As relações familiares patriarcais com amplo domínio do homem com a exigência decomportamento silencioso e comportado desenhado destoavam de qualquer investimento em ação de autonomia, quer financeira, que política. Anotemos que boa parte dessas mulheres sequer tinham o direito a ter direitos e passaram toda uma vida sem ter nenhum documento, sendo que todas as ações com o "mundo externo" como banco, por exemplo, eram realizadas pelo seu marido. O título de terra, quando a familia o conseguia, era garantida também aos homens da família.

Toda essa situação colocava para a mulher camponesa uma circunstância a mais de vulnerabilidade, fundamental no que diz respeito às relações sociais de sexo e ao enfrentame nto das diversas formas de violência a que poderia ser submetida por seus companheiros, o que ainda hoje é sentido:

(...) a nós mulheres é negado o espaço público. A nós mulheres é destinado, principalmente as mulheres do campo mais do que tudo. É destinado o espaço privado da casa, do cuidado dos filhos, do cuidado ao redor da casa, da produção de comida, mas lá a gente vê muito claro que as mulheres não vão pro banco, por exemplo, quando tem que pegar o crédito, não vão pra reunião quando o técnico vem lá no município pra poder ver que projeto que você quer, o que você vai produzir. As mulheres na sua maioria não participam dessas reuniões, então, elas nem sabem o que vai acontecer, o que significa aquele projeto, como é que ele vai se dar. Os desejos, as vontades delas não são representadas nesse espaço. Muitas não têm nem conta bancária. Ainda existe muito a questão de muitas mulheres que não tem a documentação, né? Não tem a sua documentação pessoal. Isso significa que elas não são nem reconhecidas como sujeitos pro Estado, por exemplo. Você não tem documentação, você não existe. (informação verbal) ${ }^{102}$

No que diz respeito à saúde dessas mulheres, há traços interessantes que merecem nota quanto ao modelo de agricultura dominante:

\footnotetext{
102 Entrevista concedida por Entrevistada B. [ago. 2014]. Entrevistadora: Diana Melo Pere ira. Brasília, 2014. arquivo .mp3 (52'36").
} 
Então também como é que tudo isso afeta, o quanto isso é importante, mas também o quanto isso afeta quando você vem, por exemplo, com um veneno, com um transgênico, que você planta uma horta. Você tem uma horta aqui, mas aí o marido plantou aqui em cima soja e é um morro, né? Aquele veneno vai descer e vai vir pra sua horta que você tá plantando sem veneno. Então, como é que essas questões afetam também a vida das mulheres. Tanto é que [] em cidade do sul tem alto índice de câncer por conta de agrotóxico, as mulheres são as que aparecem com mais casos de câncer, apesar de que não são elas que plantam a soja, mas qual a relação que existe de afetar a saúde das mulheres por esse modelo de agricultura do agrotóxico, do agronegócio. (informação verbal) ${ }^{103}$

A temática da saúde, sempre articulada com a ideia da prevenção e alimentação adequada e com críticas ao tratamento da vida-saúde-doença como mercadoria. Esse modo de ver a questão viria a se consubstanciar como um dos pilares do Projeto de Agricultura Camponesa. Viria a ser uma das grandes tônicas que motivariam as ações das mulheres camponesas nas linhas de formação, articulação e luta pelo Brasil.

\section{B) Forças centrífugas e o questionamento das relações sociais de classe e sexo no campo brasileiro}

\section{Um pouco da história das lutas no Brasil no campo}

Mas lembremos que o movimento não é exclusivamente centrípedo, garantindo a manutenção do status quo. Há um aspecto de dispersão no processo que garante a possibilidade dialética a partir do confronto dessa "tese" com uma "antítese". Há sempre a possibilidade de des-ordenar.

Não podemos esquecer a existência das forças centrípedas no processo.

Sobre a dupla base interpenetrante das infra-estruturas internacional e nacional é que se armam os aspectos derivados e superestruturais - de um lado, estabelecendo a coesão, e, de outro, a dispersão.

\footnotetext{
${ }^{103}$ Entrevista concedida por Entrevistada B. [ago. 2014]. Entrevistadora: Diana Melo Pereira. Brasília, 2014. arquivo .mp3 (52'36").
} 


\section{(...)}

Ponhamos, então, num ramo, as forças centrípetas. Travam-se as relações sociais, dentro do modelo infra-estrutural; estas relações adquirem certa uniformidade e a classe e grupos dominantes exprimem-nas em usos, costumes, folkways e mores (...): eles constituem os veículos da dominação e se entrosam nas instituições sociais, invocando princípios ideológicos. Tais princípios integram o mesmo domínio, sob o rótulo de "cultura", como se aquilo fosse a legítima e harmoniosa compilação do que sente e deseja todo o povo. $\mathrm{Na}$ verdade, este último pode ser iludido pela ideologia, mas, como já dizia Lincoln - engana-se uma parte do povo todo o tempo; todo o povo uma parte do tempo; nunca, porém, todo o povo todo o tempo. (LYRA FILHO, 2005, p. 44)

É verdade que o modo capitalista hegemonizou-se no Brasil desde a chegada de Portugal, mas é inegável que a existência e, principalmente, resistência de grupos com culturas diferenciadas e de relacionamento diverso com o meio ambiente, têm afrontado o sistema no ponto de concepção sobre a permanência na terra e o seu uso. Se para o capital a terra e seus produtos são mercadoria, para outras culturas a ideia sobre a terra é outra.

Aqui se vislumbram não somente os pequenos proprietários de terra, mas aquelas e aqueles que se relacionam com a terra, as florestas e a água de forma comunal, como indíge nas, ribeirinhos, quilombolas, pescadores e, de forma ainda mais especial, que estão no meio desses vários grupos, as camponesas, visto que a sua produção, dentro da divisão sexual do trabalho, tem sido aquela que efetivamente tem garantido a subsistência dos grupos familiares.

De fato, esses grupos no campo nunca deixaram de se articular contra o modelo que negava sua existência. Muitos momentos de luta e resistência foram vivenciados na história brasileira, com um grande número de revezes e um quase extermínio de outras possibilidades (lembremos que se viveu a dizimação de vários povos indígenas), mas sem determinar o completo desaparecimento de outras práticas que se confrontam com o modelo.

Houve esforço grande do sistema para deslegitimar essas "outras" formas que se confrontavam com a agricultura baseada na exportação e na alimentação da indústria, e mesmo repressão constante, a partir das forças de justiça e segurança, de quem ousasse se colocar contra a ordem dominante.

A opressão severa sobre os grupos "não brancos" e "não proprietários" foi o motor aglutinador de vários movimentos no campo de Norte a Sul do país, desde a invasão e conquista do Brasil pelos portugueses: as resistências indígenas, os quilombos, a Balaiada, Sabinada, 
Cabanagem, as Ligas Camponesas, dentre tantos outros exemplos, foram o grito de resistência contra os poderes e as instituições dominantes (JARH; PEREIRA, 2009).

Em meio a todas essas lutas, havia mulheres, embora elas pouco tenham sido mencionadas. Segundo Conte, Daron e Martins (2009):

São raras as mulheres consideradas pela historiografia oficial e, quando são lembradas, geralmente "só foram alguém por terem sido esposas de alguém importante, que as fez ser..." ou porque foi "santa" sendo morta, sacrificada por causa dos outros, etc. Além disso, o padrão existente na sociedade é urbano, então, menos ainda se sabe sobre mulheres camponesas (p. 87).

Algumas iniciativas têm sido tomadas nos últimos anos para promover o resgate do nome dessas mulheres.

Embora o "homem branco" lembre dessas mulheres como "as eróticas, as sujas, as fazedoras-de-filho, trabalhadeiras e pegas-no-laço"104, dentre as indígenas, são resgatados alguns nomes.

O Movimento de Mulheres Camponesas empreendeu um esforço para resgate de nomes e histórias das índias, negras, quilombolas, caboclas que construíram o Brasil. Deles que se consubstanciou no artigo "Todas as Vidas... Todas as Vias Camponesas!" (2009), de Elis iane de Fátima Jahr e Nancy Cardoso Pereira: Maria Coragem, índia Xucurú lutadora na Guerra do Paraguai; Juçara, índia guarani companheira de luta e de vida de Sepé Tiarajú; Dandara, liderança de Palmares ao lado de Zumbi; Teresa de Benguela, liderança do Quilombo do Piolho ao lado do companheiro José Piolho; Filipa Maria Aranha, Maria Luiza Piriá e Maria Juvita, lideranças do Quilombo do Mola; Zeferina, liderança do levante de escravos que se organizara m no Quilombo do Urubu, na Bahia, dentre muitas outras, foram nomes de mulheres lutadoras no Brasil Colônia.

Houve também mulheres organizadas na Cabanagem, Canudos, Contestado, Ligas Camponesas... Como existem ainda hoje dentro de movimentos e espaços mistos de militância,

104 “Alguns escritos indicam e confirmam o 'costume' no Brasil colônia de famílias que 'adotavam' pequenas índias para 'criar' ou homens que tomavam jovens índias à força e as mantinham como 'esposas'. Eram as chamadas índias "pegas-no-laço" (p. 25). In: JARH, Elisiane de Fátima; PEREIRA, Nancy Cardoso. Todas as Vidas... Todas as Vias Camponesas! In: PALUDO, Conceição (Org.). Mulheres, resistência e luta em defesa da vida. São Leopoldo: CEBI, 2009. 
como, por exemplo, a Comissão Pastoral da Terra (CPT) e o Movimento dos Trabalhadores e Trabalhadoras Sem Terra.

"Sem a mulher, a luta vai pela metade": a construção de um movimento autônomo de mulheres no campo

O Movimento de Mulheres Camponesas (MMC Brasil) nasce em 2004, em Brasília, mas para contar a história específica da criação de um movimento autônomo de mulheres no campo, é necessário voltar à década de 1980.

Segundo Jahr e Pereira (2009), as articulações que culminaram na criação de um movimento que reunisse as mulheres do campo de todo o Brasil, faz parte dessas lutas, mais exatamente das articulações do novo sindicalismo rural no fim da ditadura militar, em um momento de pressões pela abertura democrática.

Embora elas também fizessem parte da massa que estava no campo e que reivindica va direitos, o fato é que o sindicalismo não era lá tão igualitário assim:

A origem da participação mais orgânica de um movimento de mulheres rurais está localizada no contexto da abertura democrática da década de 1980 e na consolidação do movimento feminista e de mulheres no Brasil, Nas áreas rurais, as Comunidades Eclesiais de Base e grupos de mulheres organizados pela CPT ofereceram uma experiência de formação que desafiava as mulheres a questionar as injustiças sociais, ligadas a questões de saúde e educação. Mas os sindicatos, na década de 1980 eram predominantemente espaços de homens (JARH; PEREIRA, 2009, p. 72).

As mulheres tiveram de se organizar duplamente para fazer com que não fossem esquecidas na Constituinte. A luta inicial foi a de se fazer ouvir "entre os seus", dentro da sua própria classe. O desafio era de entrar nos sindicatos, um "espaço de homens", e fazer com que suas reivindicações entrassem no rol dos direitos na nova constituição:

O movimento de mulheres rurais procurou desenvolver algumas reivindicações básicas: a incorporação de mulheres nos sindicatos e a extensão 
dos benefícios de seguridade social, incluindo licença maternidade paga e aposentadoria para as mulheres trabalhadoras rurais. Mesmo sendo força de trabalho explorada na roça e no trabalho doméstico familiar, as mulheres continuavam excluídas tanto aos olhos do patrão como da maioria dos dirigentes sindicais. Durante a metade da década de 1980, o costume era que somente uma pessoa por família poderia ser membro do sindicato, geralmente o homem chefe de família (JARH; PEREIRA, 2009, p. 72).

Quando se trata da menção a esse início, bibliografia e testemunhos reforçam a importância de parte da Igreja Católica, em especial a Teologia da Libertação e atuação das mulheres nas Comunidades Eclesiais de Base - as CEBs -, como ponto importante desse processo:

Surgiu em Santa Catarina (...), surgiu há mais de 30 anos. Ele surgiu (...) as mulheres que estavam naquela época que são hoje dirigentes desde a constituição do movimento que elas sentiram que (...) a necessidade de que as mulheres tinham que se organizar porque essas mulheres, há 30 anos atrás foi um período que também houve o surgimento de outros movimentos como o MST e outros movimentos, CPT (...) Elas faziam até parte da organização da Eclesial de Base, que é da CPT e tal (...). (informação verbal) ${ }^{105}$

A participação nos espaços mistos ganhava força e as mulheres começavam a perceber que as suas demandas não encontravam tanta ressonância como gostariam, como já colocamos em outro momento desta dissertação.

Tratamos, no ponto anterior, sobre os usos, costumes, folkwares e mores dominantes, bem como sobre algumas de suas instituições, como o Estado e o direito estatal.

Como parte da construção do contexto do espaço de lutas no campo, chegamos agora no ponto de apresentar as "contra-instituições sociais", o "outro lado" do esquema apresentado por Lyra Filho na sua dialética social do direito.

Nesse ponto, já vamos nos restringir às articulações que, no campo, relacionaram as questões de sexo e classe social: temos a Organização das Mulheres da Roça (OMR), no Rio Grande do Sul, em 1985, embrião do que viria a se consubstanciar no Movimentos de Mulheres Trabalhadoras Rurais do Rio Grande do Sul (MMTR-RS), em 1989, e que, finalmente, viria a

\footnotetext{
105 Entrevista concedida por Entrevistada B. [ago. 2014]. Entrevistadora: Diana Melo Pereira. Brasília, 2014. arquivo .mp3 (52'36").
} 
ser o grande articulador da Articulação Nacional dos Movimentos de Trabalhadoras Rurais (ANMTR), em 1995, que, finalmente, viria a se tornar o Movimento de Mulheres Camponesas (MMC Brasil), em 2004.

Vamos contar um pouco dessa caminhada. Pensando no esquema montado por Lyra, que trouxemos acima, a história desses movimentos se confunde com a história da garantia de direitos para as mulheres do campo em um movimento de "reforma" do direito estatal como resposta às tensões entre classes espoliadora e espoliada e grupos opressores e oprimidos:

Exploração e a discriminação, é o núcleo de emergência da Organização das Mulheres da Roça, embrião do que viria a ser mais tarde o MMTR RS, que, por sua vez, compõe o MMC Brasil (CONTE; MARTINS; DARON, 2009, p. 94).

Percebe-se um relato com a marca do Rio Grande do Sul muito forte na construção dessa história. Em outros Estados, no entanto, tivemos movimentos parecidos que acabaram culminando (ou não) na articulação que deu origem ao Movimento de Mulheres Camponesas (MMC). Em 2004, o MMC Brasil unificou 16 organizações em 16 Estados, distribuídas nas cinco regiões do país.

Boa parte das histórias de construção do MMC vem a resgatar sua origem a partir dos movimentos do Sul do país, principalmente Santa Catarina (Movimento de Mulheres Agricultoras) e o Rio Grande do Sul (OMR e MMTR-RS), até porque esses textos são escritos a partir da fala das militantes que, participando desses movimentos locais, contribuíram com a articulação do movimento nacional. Os textos, no entanto, fazem sempre a menção a outros vários movimentos de mulheres no campo que tiveram seu surgimento concomitante.

Em uma das entrevistas, houve a menção de que há mesmo a necessidade de ir antes e reconstruir a história das tentativas de construção de um movimento nacional de mulheres no campo:

Foram um, dois anos ou três nós fizemos o segundo encontro nacional em Goiânia. E aí foi muito interessante porque em Goiânia, um encontro lindo, muita gente, muitas mulheres. E aí quando a gente começa a recuperar documentos de que teve duas tentativas na história do Brasil de construção do movimento nacional. Então, outras mulheres, há não sei quantos anos atrás 
tiveram essa ideia e não conseguiram, não deram conta. Imagina se hoje é difícil, imagina lá na década de 50 isso. (...) E aí a gente não tava fazendo o segundo encontro, a gente estava fazendo o quarto. Eu acho que tem uma dívida do MMC com essas mulheres. Acho que a gente precisa resgatar essa história. Esses documentos, onde estão, quem eram essas mulheres. Que era uma parada de louco, mas era uma estratégia fantástica das mulheres. (informação verbal) ${ }^{106}$

Conseguimos reunir algumas informações, durante a iniciativa deste trabalho, sobre a articulação de um movimento no Nordeste, originário também na década de 1980, e que ainda hoje atua: o Movimento de Mulheres Trabalhadoras Rurais do Nordeste (MMTR-NE), a partir da informação verbal que nos foi repassada em uma das entrevistas:

P - Tu já me falou [em outra conversa não gravada] que eram os movimentos do sul, Santa Catarina, Rio Grande do Sul e Pará. Do Nordeste quem era?

E - No Nordeste tem um movimento até hoje chamado Movimento de Mulheres Trabalhadoras Rurais do Nordeste. Que já existia. Não sei a data, mas ele é muito antigo também e aí as mulheres (...) A Justina, a Loiva, que começaram esse debate. Elas foram pro Nordeste, inclusive. Fizeram muitos debates no Nordeste. (...) Mas elas já tinham na sua cabeça o projeto de construção do movimento nacional que pra gente foi cair a ficha muito depois. Que isso era um trabalho de base inclusive pra gente, né? Que eu acho isso assim, uma história fantástica. Da estratégia dessas companheiras. Uma coisa é você fazer uma luta localizada, estadual e tal. Outra coisa é você fazer construir um movimento nacional, assim, cara, no Brasil de 500 anos, as mulheres têm a petulância (risos) de se organizar em um movimento nacional. Assim, foi de uma capacidade de estratégia e elaboração que a gente deve muito a essas companheiras. (informação verbal) ${ }^{107}$

O Movimento de Mulheres Trabalhadoras Rurais do Nordeste (MMTR-NE) terminou por se constituir enquanto associação civil e desenvolvendo, ao que parece, ações mais típicas das chamadas Organizações da Sociedade Civil (OSCs), como projetos de educação popular e publicações. Ao que parece, o Movimento de Mulheres Camponesas adota mais um perfil de "movimento social", mas essa é uma avaliação que admitimos ser um tanto superficial. Uma

\footnotetext{
${ }^{106}$ Entrevista concedida por Entrevistada A. [ago. 2014]. Entrevistadora: Diana Melo Pereira. Brasilia, 2014. arquivo .mp3 (26'11").

107 Entrevista concedida por Entrevistada A. [ago. 2014]. Entrevistadora: Diana Melo Pereira. Brasília, 2014. arquivo .mp3 (26'11").
} 
diferenciação entre os dois merecia um estudo de maior profundidade para conclusões mais certas.

Feita a ressalva, utilizaremos a história mais detalhada a partir do Rio Grande do Sul, para que possamos perceber como foi construída a ideia de um movimento autônomo pelas, até aquele momento, mulheres "da roça", quando elas, em tese, poderiam atuar dentro dos espaços mistos.

Durante o ano de 1985, aconteceu o pontapé inicial para a construção de um movimento autônomo de mulheres: durante a candidatura de Pedro Simon, para o governo do Rio Grande do Sul, foi articulado um grande encontro de mulheres do campo na cidade de Porto Alegre.

Durante o encontro, quando ficou clara que a sua perspectiva tinha fim exclusivamente eleitoral, as mulheres lá presentes se dividiram em três grupos: um deles se nomeou "Margaridas" e declarou seu apoio à candidatura; o outro de mulheres sindicalizadas que continuariam a tentar sua militância dentro do espaço misto da FETAG-RS e o outro que reivindicaria a construção de um movimento autônomo e que viria a criar no mesmo ano de 1985 a Organização de Mulheres da Roça no Rio Grande do Sul (OMR).

As mulheres da OMR reivindicavam a sua autonomia frente a partidos políticos. Essa demarcação veio em resposta à proposta não clara em relação ao encontro montado para apoio à candidatura acima colocada. Posteriormente, a organização do MMTR-RS e o MMC, apesar de deixar clara a sua independência face aos partidos, têm se envolvido em períodos eleitorais apoiando candidaturas que possam somar mais com um projeto de agricultura camponesa e de promoção de direitos das mulheres em um campo nomeado democrático e popular.

A Organização de Mulheres da Roça, de pronto, também já começava a desenhar uma crítica à naturalização da mulher na divisão sexual do trabalho no campo e reafirmava a necessidade de sua existência como movimento autônomo a partir da percepção que os outros espaços não as contemplavam.

Desde o início realizavam críticas a EMATER, que reforçava o papel da mulher como "rainha do lar" e doméstica. Frisamos que a empresa estatal era conduzida por lideranças masculinas de sindicatos, partidos políticos e outras instituições e precisava abrir-se para entender o contexto das mulheres e proporcionar políticas que lhes garantissem mais autonomia. 
A reação dos outros movimentos, principalmente dos homens, reforce-se, não era muito simpática à criação de um movimento autônomo e ficava cada mais evidenciado que a saída das mulheres de casa para fazer política implicaria não só mudança externa com a inscrição de seus direitos no direito estatal, mas mudança das relações na divisão sexual do trabalho:

No período de 1985 a 1989, foi intensa a mobilização das mulheres, com muitas lideranças que iam e vinham com informações nas comunidades. Consta que se arrecadava dinheiro entre todas e também com entidades parceiras, para que as lideranças pudessem viajar a Capital Federal. As incertezas e inseguranças eram muitas, mas a grande certeza era de que elas queriam os seus direitos, até então negados. Muitos apostavam que elas estavam perdendo tempo e que não conseguiriam coisa alguma. Aparecia fortemente o machismo, por parte de homens, especialmente, em função do me do de perde rem o poder/controle sobre "suas mulheres". De repente e las começaram a falar em dire itos e estavam saindo de casa, re unindo-se nas comunidades. Algumas iam para outros municípios. As mais ousadas, as lideranças, viajavam para longe, davam entre vistas às rádios e isso deixava um me do no ar... Aonde elas iam chegar?" (CONTE, MARTINS, DARON, 2009, p. 98). ${ }^{108}$

Mesmo assim, as mulheres conseguiram trilhar de Norte a Sul do Brasil, em especial, Loiva Rubenith, dentre outras, que conseguiam fazer as travessias arrecadando dinheiro entre as próprias mulheres e algumas organizações, dormiam no meio do caminho nas casas de outras militantes e assim seguiam viagem. A bandeira utilizada para o convencimento da necessidade de construção de um movimento nacional eram a previdência e a documentação para as mulheres:

(...) essas companheiras foi que pensaram mais essa estratégia da organização nacional então. A luta da previdência e da documentação foi uma estratégia pra chegar em todos os cantos desse país. Era na verdade uma tática, porque a estratégia maior era a construção de um movimento nacional que debatesse a questão da mulher trabalhadora rural no país. (informação verbal) ${ }^{109}$

\footnotetext{
108 Sem grifo no original.

109 Entrevista concedida por Entrevistada A. [ago. 2014]. Entrevistadora: Diana Melo Pereira. Brasília, 2014. arquivo .mp3 (26'11").
} 
A cada vitória da articulação das roceiras e inscrição de uma nova letra no rol do direito estatal e seus aparelhos, acontecia uma consequente possibilidade de mais liberdade para as mulheres. O problema é que, diante dessa possibilidade de liberdade, verificou-se uma resistência dos homens "da rua", ou seja, os que deveriam ser companheiros de luta política e "da casa", ou pais, irmãos e companheiros de vida amorosa, que sentiam a perda do poder sobre "suas" mulheres:

\begin{abstract}
Ainda em 1995, após muita luta pelo direito a documentação pessoal e profissional, as mulheres foram autorizadas a colocar seus nomes nos blocos de notas da venda de produtos agrícolas. Foi mais uma grande conquista, fruto de intensa mobilização nos municípios e no Estado, cujo maior entrave era o machismo manifestado por parte de funcionários dos órgãos públicos competentes, STR's [Sindicatos de Trabalhadores Rurais] e pelos próprios companheiros das mulheres trabalhadoras. Segundo uma testemunha que viveu o período de luta, os homens viam seu poder ame açado mais uma vez. Conta-se que o maior medo, por parte deles, era que as mulheres viessem a coordenar/mandar e definir sobre as finanças da venda de produtos (CONTE; MARTINS; DARON, 2009, p. 108)..$^{10^{3}}$
\end{abstract}

Os blocos de nota configuram-se com uma das provas de que a atividade agrícola é desempenhada. Ela serve para uma série de comprovações como prova de renda e tempo de exercício de atividade para fins de aposentadoria ${ }^{111}$. As notas eram comumente feitas em nome dos homens e as mulheres não tinham como comprovar que eram trabalhadoras rurais. Ter os blocos de nota em seu nome significava uma possibilidade de mais poder para as mulheres, e isso incomodava, como pôde ser observado acima.

O nascimento do Movimento de Mulheres Camponesas (MMC Brasil) aconteceu em meio a essas disputas dentro do próprio campo de lutas sociais com os homens. Mas as mulheres, que já estavam há quase duas décadas de lutas e articulação, com algumas vitórias consideráveis, já percebiam que não precisavam mais pedir licença para se organizar. Perceberam que eram donas de si próprias. Que não teriam mais quem falasse por elas na rua e nem quem mandasse nelas em casa:

Com identidade feminista e classista e a legitimidade de quem já havia aglutinado anos de história de luta, militantes e dirigentes reafirmaram a

\footnotetext{
110 Sem grifo no original.

111 Ministério da Previdência Social, "Documentos de Comprovação de Atividade Rural para benefício rural". Disponível em: <http://www8.dataprev.gov.br/e-aps/servico/300>. Acesso em: 10 dez. 2014.
} 
necessidade de autonomia. Ficou explícito, no processo, que o patriarcado perpassa inclusive as organizações de esquerda. A resposta das mulheres foi de que elas superaram a fase de necessitar pedir licença ou favor: "quem sente e sabe do que as mulheres podem e devem são elas mesmas". "quem sente e sabe da opressão patriarcal, além a opressão do capital, deve reagir contra ambos (CONTE, 2009, p. 115).

Nesses 10 anos de existência, o Movimento de Mulheres Camponesas conseguiu inegável espaço dentre os movimentos mistos, embora acreditemos que isso ainda não é destituído de conflitos. Em uma busca rápida pelas declarações da Via Campesina no Brasil, por exemplo, percebemos que é o MMC Brasil a falar pela organização internacional ${ }^{112}$.

O Movimento de Mulheres Camponesas, ademais, conseguiu sustentar críticas ao modo de produção capitalista no campo, quando os próprios companheiros dos outros movimentos ainda não tinham assumidos as bandeiras, por exemplo, da alimentação saudável e contrária à utilização dos transgênicos.

O Movimento assumiu de imediato uma posição contrária ao plantio de transgênicos. Essa posição tornou o período difícil, pois as mulheres assumiriam a discussão dentro de casa, enquanto os companheiros de grande parte delas defendiam o contrário. De certa forma, mas entrelinhas, o Movimento foi responsabilizado por causar "desavenças no lar" (CONTE, 2009, p. 115).

Um dos grandes desafios, não só do MMC Brasil, mas como de todos os movime ntos de mulheres no campo, e mesmo na cidade, diga-se de passagem, é o de combater o machis mo diariamente praticado contra elas, quer no espaço da militância, quer no reconhecimento do trabalho que desempenham e garantias para que tenham mais poder econômico, quer quando a questão da violência chega na violência física, patrimonial, sexual e/ou psicológica compreendida dentro da Lei Maria da Penha.

\footnotetext{
112 A título de exemplo, colocamos a entrevista concedida por liderança do MMC Brasil, Rosângela Piovizani, em representação pela Via Campesina. A entrevista foi concedida à Frente Parlamentar Ambientalista sobre as mudanças do Código Florestal: <https://www.youtube.com/watch?v=bzxPPiz_If4>. Acesso em 20 dez. 2014.
} 


\subsubsection{Luta por direitos: espaços institucionais e a atividade anômica organizada}

Como último ponto deste trabalho, acreditamos ser interessante discorrer acerca das lutas por direitos desenvolvidas pelo Movimento de Mulheres Camponesas (MMC Brasil), quer por métodos aceitos pela institucionalidade, quer pelo que Lyra Filho chama de "atividade anômala".

\section{A) Lutas dentro da institucionalidade}

No período de observação participante, pudemos assistir a algumas atividades promovidas pelo Movimento de Mulheres Camponesas em mesas de diálogo com o Poder Público para mudanças de perspectivas ou fortalecimento de ações que visassem ao combate à violência contra as mulheres. Dentre elas, podemos citar uma série de ações junto ao parlamento com reuniões com deputados e senadores, e uma audiência pública em parceria com a Articulação de Mulheres Brasileiras (AMB), em 2013, e a realização do I Encontro Nacional de Mulheres Camponesas, financiado, em parte, com apoio de alguns órgãos do Poder Público Distrital e do governo federal.

O que mais chamou nossa atenção nas iniciativas foi a resposta dos poderes públicos, mais especificamente a respeito das justificativas para a promoção, proteção e garantia dos direitos das mulheres, muito centradas no fato de que elas são mães, cuidam das crianças e por isso merecem uma proteção diferenciada.

Durante o I Encontro Nacional de Mulheres Camponesas, o discurso ${ }^{113}$ da presidenta Dilma Rousseff versou, em grande parte do seu conteúdo sobre essa temática, sobre um longo caminho a ser percorrido para que a compreensão dos poderes públicos seja transformada a respeito dos papéis convencionais atribuídos às mulheres e para que ocorra uma consequente repercussão dessa visão sobre o (não) desenvolvimento de políticas destinadas às mulheres.

\footnotetext{
113 Disponível em: <http://www2.planalto.gov.br/centrais-de-conteudos/videos/video-do-discurso-da-presidentada-republica-dilma-rous seff-no-1o-encontro-nacional-do-movimento-de-mulheres-ca mpones as-mmc-brasiliadf>. Acesso em: 20 set. 2014.
} 
Por outro lado, simbolicamente, o fato de a presidenta ter comparecido ao Encontro Nacional não deixou de ser sentido pelas camponesas, que estavam presentes no evento, como importante para o fortalecimento da ideia de que elas, como mulheres, também poderiam participar da política, que aquele também era o lugar delas. Há que se perguntar até que ponto também a presença possa ter contribuído para uma abertura de diálogo com a presidenta para as pautas das camponesas, articulando sexo e classe social no campo.

Uma outra questão com que pudemos entrar em contato diretamente, durante o período de observação participante, foi com a crítica do Movimento de Mulheres Camponesas a respeito das políticas específicas desenvolvidas para enfrentamento à violência contra as mulheres do campo e das florestas que estavam centralizadas na garantia de atendimento itinerante das mulheres em situação de violência, por meio de unidades móveis ${ }^{114}$.

Tanto em reuniões internas do movimento, as quais tivemos a autorização para participação como pesquisadora, como na miniplenária específica durante o I Encontro Nacional, sobre violência contra a mulher praticada por parceiro íntimo, do qual pudemos participar inclusive como relatora, a fala se repetia no sentido de questionamento da política centrada nas Unidades Móveis. As questões eram relacionadas com a retaguarda que a mulher teria depois da denúncia, visto que as unidades, como o próprio nome já informa, não permaneceriam no local. Além disso, lançaram questões a respeito de garantias às políticas para que as camponesas pudessem ter acesso à independência econômica.

\section{B) "Nós caladas rompemos o silêncio": Lutas "fora" da institucionalidade e atividade anômica promovida pelas mulheres camponesas}

Do rio que tudo arrasta se diz que é violento. Mas ninguém diz violentas as margens que o comprimem”

Bertold Brecht

\footnotetext{
114 "Unidades Móveis para atendimento a mulheres em situação de violência no campo e na floresta por SPM", publicado em 27 de janeiro de 2015. Disponível em: <http://www.spm.gov.br/assuntos/violencia/programamulher-viver-sem-violencia/unidades-moveis-para-atendimento-a-mulheres-em-situacao-de-violencia-nocampo-e-na-floresta>. Acesso em: 20 fev. 2015.
} 
Desde as primeiras articulações da Organização de Mulheres da Roça, passando pelas ações articuladas dos Movimentos de Mulheres Trabalhadoras Rurais pelo Brasil (MMTRs), até as ações desenvolvidas pelo Movimento de Mulheres Camponesas, em nome próprio, ou a partir da Via Campesina, houve muitas atividades de pressão para transformação do sistema e do direito estatal.

A chamada "atividade anômica", na Dialética Social do Direito de Lyra Filho, ocorre em meio às contradições do sistema, que não consegue garantir passividade e conteção dos grupos e classes sociais:

O controle social global, isto é, como dissemos, a central de operações das normas dominantes, do e no setor centrípeto, dinamiza em aspectos, não isentos de contradições, a organização social militante. Aíé que surgem as leis de todo o tipo, inclusive as anômalas; que rompem (para a garantia da organização subjacente) o próprio sistema legal, quando classe e grupos dominantes se assustam com a possibilidade mais ou menos próxima de verem escapar o controle social da mão das "elites do poder" (LYRA FILHO, 2005, p. 48-49)

Diante dos conflitos com o controle social global, há a pressão organizada (ou não) para transformação do sistema de forma global, atingindo o modo de produção, ou buscando reformas dentro desse mesmo modo:

VIII - Parece, então, claro que a coexistência conflitual de séries de normas jurídicas, dentro da estrutura social (pluralismo dialético), leva à atividade anômica (de contestação), na medida em que grupos e classes dominados procuram o reconhecimento de suas formações contra-institucionais, em desafio às normas dominantes (anomia). Este projeto, entretanto, pode ser de dois tipos: ou se revela apenas reformista, enquanto visa a absorção de seus princípios e normas pela central do ramo centrípeto (ponto VI), sem atingir as bases da estrutura e os demais aspectos da normação dominadora; ou se mostra revolucionário, isto é, delineia o contraste fundamental, com uma série de princípios e normas que são proposta e prática reestruturadora, atingindo a infra-estrutura e tudo o que sobre ela assenta. Reforma ou revolução representam o enlace jurídico-político; isto é, só politicamente se instrumentalizam e tem chance de triunfar; mas só juridicamente podem fundamentar-se (a dinamização é política; a substância é jurídica). E a fundamentação jurídica é indispensável para validar, inclusive, o apelo revolucionário e introduz ao mais amplo círculo do Direito, que, por isto mesmo, no esquema dialético, pusemos numa chave envolvente, com a designação de IX (LYRA FILHO, 2005, p. 50). 
Nesse sentido, faz-se importante verificar como as mulheres camponesas têm se comportado na construção e defesa de suas pautas, visando, ora reforma do sistema, ora traçando um tensionamento que o questiona em seu âmago, de modo que vamos fazer uma passagem por algumas dessas ações.

No que diz respeito ao rol de direitos reivindicados, já mencionamos neste trabalho que a primeira pauta que articulou as mulheres camponesas foi a das garantias trabalhistas e previdenciárias para as mulheres. Em decorrência dela logo se percebeu a importância da documentação das mulheres rurais e da garantia de que a terra rural também viesse em seu nome. Com o tempo, foi inserida também a pauta do direito à saúde, em uma perspectiva que ultrapassasse a visão materno-infantil. Por fim, de forma articulada à pauta da saúde e da identidade camponesa, foi inserida a pauta do direito à alimentação saudável e o consequente combate aos transgênicos e agrotóxicos.

Dentre os mais de 20 anos de luta, considerando desde as articulações pela constituinte da "roça", consideramos alguns eventos dignos de nota no que diz respeito à atividade anômica: as ações relacionadas à conquista do direito à aposentadoria, salário-maternidade e protestos contra o modelo que não privilegia a produção de alimentos saudáveis, do qual o ato contra a Aracruz Celulose foi o mais divulgado.

Várias lutas, mobilizações e articulações foram necessárias para a garantia do direito à aposentadoria para as mulheres da roça, mas a ação que de fato garantiu efetivamente que a esta fosse regulamentada fez uso de métodos fora da institucionalidade e atingiu diretamente um ministro de Estado:

\begin{abstract}
A conquista da aposentadoria, de fato, deu-se com a ocupação do Ministério da Previdência por mais de 600 mulheres trabalhadoras rurais, de diversos estados do Brasil. As mulheres ocuparam todas as salas e corredores possíveis, permanecendo ali durante um dia. $\mathrm{O}$ então ministro da previdência, $\mathrm{Sr}$. Antônio Britto, foi sequestrado em sua sala, proibido de usar o telefone, até assinar os documentos que regulamentavam o direito de aposentadoria dos trabalhadores e trabalhadoras do campo. Uma mulher anunciou o sequestro e muitas delas, que se encontravam nos corredores, como forma de pressão, arrancaram as persianas das janelas do Ministério (CONTE, 2009, p. 103).
\end{abstract}

Da mesma forma, ocorreu em relação às reivindicações do salário-maternidade para as camponesas em 1993: 
Os meses de agosto e setembro de 1993 foram marcados pela reinvindicação do Salário Maternidade no Brasil, que continuava em pauta, articulada com o direito a saúde. Foram diversas caravanas a Brasília com a participação de 120 mulheres do MMTR/RS. Eram mais de 800 mulheres em Brasilia, para as quais, "como não havia espaço disponível", tiveram que montar acampamento em um estábulo. Enquanto a comissão de mulheres negociava, as demais permaneciam em frente aos órgãos públicos, pressionando e ameaçandoentrar nos prédios, caso suas reivindicações não fossem atendidas. Junto com essa luta, o Movimento avançava na organização, desenvolvendo processos de formação e conscientização com as mulheres trabalhadoras rurais (MMTR/RS, s.d) (CONTE, 2009, p. 104).

Ainda no mesmo sentido, os atos desenvolvidos em relação à defesa da agricultura camponesa em combate ao agronegócio, sementes transgênicas e agrotóxicos:

O ano de 1997 foi marcado por amplos debates sobre o modelo agrícola, na tentativa de negar o pacote agro-químico e as monoculturas e por mobilizações conjuntas com outros movimentos, que reivindicavam crédito subsidiado para a agricultura familiar. $\mathrm{O}$ auge dessa luta foram os dezessete dias de fome, feito por um grupo de agricultores, militantes de movimentos populares, dentre os quais esteve presente uma dirigente do MMTR/RS, enquanto outras mulheres constituíam parte da coordenação e envolviam-se na negociação da mobilização.

Coincidindo com a greve de fome, acontecia a visita do Papa João Paulo II ao Rio de Janeiro e o grupo em greve ameaçava ir até o pontífice com o intuito de mostrar o descaso para com a agricultura camponesa pelos governantes do Brasil, caso as reivindicações do povo na rua não fossem atendidas. O governo cedeu a pressão. (CONTE, 2009, p. 108-109).

Por fim, destacamos o ato que ocorreu no 8 de março de 2006, na fazenda em que a Aracruz Celulose também utilizava para pesquisas em relação à plantação de eucalipto para a produção em massa de papel.

As mulheres chegaram em siêncio e destruíram as mudas em uma ação que ganhou a mídia nacional e internacional. Há muito questionavam o modelo do agronegócio e a inserção de cultivos, mesmo contra a legislação ambiental brasileira. Sem resposta do próprio Estado. Daí dissessem depois que "nós caladas, rompemos o silêncio":

Enfim, chegaram mais de 1200 mulheres ao assentamento Lagoa do Junco, em Tapes, no amanhecer do dia sete de março. Estavam presentes mulheres 
de diversas organizações camponesas do Estado do RS e de outros estados do Brasil.

E foram mulheres simples, trabalhadoras, com os rostos cansados das lutas do dia a dia: mães, avós, senhoras, jovens, que sentiam a força do coletivo, que fizeram barulho como uma tormenta.

Muitas lideranças e autoridades não esperavam que acontecesse tal ação, a qual quebrou o encantamento sobre uma grande violência velada, apesar de muito visivel. As mulheres se ergueram de incapazes a protagonistas, capazes e perigosas, produzindo uma grande surpresa que a Confereência da FAO jamais esperaria acontecer no Brasil. O perigo que isso representou foi, acima de tudo, a capacidade de pensamento, articulação e ação (CARLOS; CONTE, 2009, p. 157).

Em relação a esta última atividade anômica mencionada, cabe tecer mais algumas considerações, de modo a fechar este trabalho, dada à sua importância para o Movimento de Mulheres Camponesas, e mesmo para toda a pauta do direito a uma alimentação saudável.

A ação foi articulada a partir das mulheres da Via Campesina, mas em parte das notícias sequer mencionaram que a ação foi desenvolvida por mulheres, como vimos no começo deste capítulo.

Houve quem dissesse também que as camponesas foram manipuladas pelos homens do MST:

Obviamente a imprensa vociferante tratou de alarmar que as mulheres foram enganadas, "coitadas, que fizeram a mando dos homens, braços do MST". Mas elas não foram braços de ninguém. Foram elas, as mulheres camponesas, com seus braços e indignações, articulações e construções. Teria sido isso que tanto machucou a estrutura patriarcal e capitalista? Será que conseguiram perceber que mulher possui capacidade de planejamento e execução? Serão ainda capazes de multiplicar piadas machistas, menosprezando mulheres loiras, sogras e tantas outras...? (CARLOS; CONTE, 2009, p. 157).

Embora as notícias a respeito da organização do ato, a polícia, no entanto, "soube bem" onde procurar por "provas", identificando que o Movimento de Mulheres Camponesas tinha se envolvido de alguma forma no ato. Sem mandado judicial, invadiram as secretarias da Associação de Mulheres Camponeas estadual e nacional: 
Seis agentes da polícia civil, duas mulheres e quatro homens, um deles delegado, invadiram as secretarias. Na casa havia oito mulheres e uma criança, além das trabalhadoras. A polícia agiu como se estivesse procurando bandidos, criminosos da pior espécie. A invasão na secretaria nacional, por exemplo, aconteceu sem mandado de busca, os policiais reviraram tudo e encurralaram as mulheres na cozinha. Apreenderam todas as CPUs dos computadores, levaram materiais e documentos.

As mulheres foram levadas a delegacia e, por um bom tempo, proibidas de se comunicarem com o advogado. Foram obrigadas a assinar a intimação e, equanto isso acontecia, as policiais esparramavam e derrubavam no chão tudo o que podiam, à procura de provas e levaram tudo o que puderam. Os materiais de estudo, arquivos e sacolas com objetos pessoais foram jogados todos no chão. Foram tratadas com palavrões e xingamentos o tempo todo (CARLOS; CONTE, 2009, p. 163-164).

O ato causou várias repercussões positivas e negativas para a luta do Movimento de Mulheres Camponesas e sua organização, no combate a todas as formas de violência contra as mulheres.

Houve a criminalização de integrantes do movimento, a invasão de sua secretaria e perda de documentos, como vimos acima, mas houve também uma grande visibilidade em relação à questão e fortalecimento das mulheres enquanto interlocutoras do tema, garantindo que as pautas específicas das mulheres fossem tratadas em relação às pautas mais "amplas".

Mesmo após todas as dificuldades, as mulheres camponesas continuam acreditando na estratégia de pressão mesmo fora da institucionalidade e acreditam que essa é uma forma de combate à violência contra a mulher. 


\section{CONSIDERAÇÕES FINAIS}

Depois de um trabalho como este, em que se envolve de corpo e alma, é necessário voltar à primeira pessoa do singular para escrever. Assim farei.

Eu me redescobri no processo da escrita, principalmente porque vivi na pele o que é ser mulher em uma sociedade marcada pela divisão sexual do trabalho. Até então protegida pelos meus privilégios de classe e por uma certa abertura dentro da minha família, havia conseguido me livrar um pouco de algumas amarras colocadas pelo patriarcado.

Ser mãe, e ser mãe solteira, mais especificamente, me colocou bem no "meu lugar" e pude sentir um pouco dos desafios de existir enquanto mulher na nossa sociedade, lutando para viver e sorrir e conseguir acabar de escrever uma dissertação mesmo com o filho chorando aos meus pés e subindo na cadeira enquanto escrevo. A última do João Francisco, neste minuto, foi de segurar meus dedos para que eu não digitasse mais.

A imersão teórica, a vivência com as camponesas e a luta que elas conseguiram desenvolver a respeito de uma compreensão mais ampla do que é a violência contra a mulher, sem sombra de dúvidas, vão me marcar pelo resto da vida, como pesquisadora, como militante feminista, como profissional na advocacia popular e como pessoa condicionada pelas relações sociais de sexo.

Acredito que as lições aprendidas por mim devam marcar também uma outra perspectiva de trabalho com a temática da violência contra a mulher, no que diz respeito ao questionamento a partir da educação popular.

Durante a observação participante, pude presenciar uma atividade mista (para homens e mulheres) de educação popular realizada por liderança do MMC Brasil para integrantes de vários movimentos de luta pela terra. $\mathrm{O}$ trabalho foi realizado no sentido de questionamento da divisão sexual do trabalho e as implicações desta nas várias violências que podem ser perpetradas nas relações conjugais. O raciocínio partia sempre da conjuntura do campo, do que era ser homem e mulher neste, das tarefas realizadas e de como isso repercutia nas relações sociais de sexo.

Um dos grandes aprendizados com o Movimento de Mulheres Camponesas é de que as questões relativas à violência somente são tratadas depois de um ganho efetivo de confiança 
com as mulheres e isso também tem a ver com as questões econômicas que as limitam. O MMC constrói o debate a partir da discussão sobre o que é ser materialmente uma mulher camponesa e quais os entraves e as possibilidades de libertação política e econômica delas.

O tema da violência não é tratado diretamente como se costuma fazer nos espaços urbanos, mas relacionado a essa condição de ser camponesa. A questão econômica e a divisão sexual do trabalho são os motes, portanto, do processo de questionamento de toda uma ordem da qual as violências física, psicológica, patrimonial e sexual são "apenas" a exacerbação desse controle sobre o corpo e a vida das mulheres.

É a pauta do trabalho e do valor do conhecimento das mulheres camponesas os grandes motores que fomentam e trazem a possibilidade de articulação do movimento a nível nacional. É de forma congregada à questão do trabalho que uma visão crítica do patriarcado é construída e as mulheres chamadas a refletir sobre suas relações privadas.

Pude apreender, também, a partir da comparação entre as minhas práticas feministas no espaço urbano, que o privado no Movimento de Mulheres Camponesas pode ser trabalhado de forma diversa daquele, como já repisamos, ou, melhor dizendo, de forma diversa de como a academia vem tomando a questão das mulheres, que foi englobada pelas ditas "questões de gênero".

Defendo que há, desde a década de 1990, uma centralização do debate sobre o feminismo e os direitos das mulheres no que diz respeito aos direitos sexuais e reprodutivos e outros direitos mais voltados ao debate sobre cultura de opressão/ libertação.

Nesse ínterim, os estudos desenvolvidos adotam visão analítica mais focada nas repercussões culturais sobre as individualidades das mulheres e dos homens em uma perspectiva do gênero como categoria relacional (crescendo cada vez mais o interesse em estudos e políticas voltadas para homens agressores, por exemplo), em um debate que tem se tornado tradicional na pauta da violência doméstica, deixando de lado qualquer debate sobre classe social, porque, enfim, essa é uma questão que atinge a todas e todos de forma indiscriminada.

Não desmereço aqui a necessidade do debate desenvolvido nessas áreas e destaco a importância do enfoque que transita entre a cultura existente e as possibilidades de insurgência/transformação dos indivíduos, porém, tomo como curioso que somente essa linha prevaleça em detrimento de uma possibilidade de debate articulado com as repercussões da classe social para a percepção e o enfrentamento à violência contra a mulher. 
Mas, e o movimento organizado no MMC? Como se posicionam essas mulheres? Ora, elas assumem as pautas acima e trabalham com a formação de sua base, mas constroem isso de forma articulada ao trabalho, que guarda a centralidade.

A tomada do trabalho como central no debate as impede de fazer o debate sobre cultura? Entendemos que não. Mas, sem sombra de dúvidas, temos aí um método diferente.

O interessante é que, apesar de uma dita não centralidade das pautas mais tradicionais do feminismo, como o de publicização de questões ditas privadas, como o controle da sexualidade e o corpo das mulheres e de outras formas de violência doméstica, o MMC toca na questão, mas desenha um caminho até ela.

Realiza, em uma primeira linha, um intenso debate sobre a importância do trabalho das mulheres e a importância da participação política delas em todas as decisões relacionadas à produção, questiona, em seguida, as relações privadas a partir da divisão sexual do trabalho e, finalmente, toca em todas as restrições e os obstáculos das mulheres para a participação política, o que implica, de antemão, que elas sejam donas das próprias vidas. O debate sobre violência e restrição ao espaço doméstico aparece aí, o que tem aberto espaço, por sua vez, para questionamento de tudo que envolva o controle das mulheres.

Isso se dá, muitas vezes, na prática diária, quando a mulher, para poder ocupar o espaço público no Movimento, coloca a premência de que suas tarefas sejam assumidas pelos homens da casa.

A pauta do trabalho as coloca, também, lado a lado com outros movimentos do campo na crítica ao capitalismo e ao modelo hegemônico no campo: o agronegócio e seus impactos sobre a classe camponesa e, de modo mais especial, sobre as mulheres camponesas.

Elaboram, pois, uma crítica ao modo de produção da sociedade e suas repercussões para a vida e saúde das mulheres no campo, esclarecendo que há uma ligação muito importante entre capitalismo e patriarcado, ambos articulados oprimindo as mulheres camponesas.

O MMC faz a crítica econômica mais tradicional, denunciando que o projeto capitalis ta para o campo, a partir do modelo do agronegócio, gera pobreza porque concentra grandes porções de terra nas mãos de poucos; não enfrenta o combate à fome, porque a maioria das terras é direcionada para monocultivos destinados à exportação e, por fim, é um modelo que gera doença e malefícios à saúde, porque, quando produz alimento, utiliza sementes transgênicas e agrotóxicos. 
Na mesma linha, o MMC questiona o discurso que coloca o uso de agrotóxicos como necessário ao barateamento dos produtos agrícolas e a produção de alimentos em massa para as camadas populares, denunciando-o como falacioso.

É importante anotar que a diferenciação de preços hoje existente, vem, não de elevação de produtividade de alimentos produzidos com agrotóxicos, mas, antes, tendo em vista que a distribuição de terras e o financiamento público privilegiam o agronegócio e, por conseguinte, o tornam, em tese, mais barato. Sem contar que a simples existência do cultivo com agrotóxicos tende a inviabilizar a produção agroecológica, porque contamina os solos e as águas.

Aqui, frisemos, o em tese, porque, de um lado, os custos decorrentes da produção são repassados para os cofres públicos que emprestam dinheiro a baixos juros, garantido subvenções e concessões de terras e sustentados por um judiciário que legitima de antemão o latifúndio, mesmo que diante de suspeita de grilagem, frente a ocupantes de terra.

De outro, questiona-se o baixo custo, frente aos gastos realizados com saúde pública em razão da utilização de agrotóxicos e sementes transgênicas, que ainda são uma incógnita. Apesar de alguns estudos realizados sobre os impactos dos agrotóxicos para a saúde, e mesmo ações judiciais decorrentes da comprovação de liame entre uso de veneno e doenças ou mortes, não há interesse sério público ou privado para financiar estudos que comprovem as consequências da utilização de agrotóxicos em larga escala.

No âmbito das ações desenvolvidas pelo MMC, na atividade anômica, ou seja, contrária à ordem instituída, por meio de métodos que têm sido inclusive crimina lizados por essa ordem, mexeram bastante comigo também porque negam o imaginário sobre o que se espera de uma ação de mulheres, quanto mais de camponesas. Fortaleceram em mim a coragem para tomada de posicionamentos de enfrentamento ao sistema. Por outro lado, me fizeram perceber o quanto as classes e os grupos sociais que estão no poder podem reagir de forma ainda mais violenta frente ao questionamento de sua posição e de seus privilégios.

Por fim, das lições aprendidas que merecem ressalva, falo dos desafios específicos que as mulheres sofrem para se organizar e lutar dentro da própria esquerda e dos movimentos populares. A história da organização do Movimento de Mulheres Camponesas como um movimento autônomo que questiona, inclusive, o poder dos homens que são companheiros de classe social e de vida, demonstra o quanto há para se caminhar em relação à compreensão da articulação das questões de sexo e classe social dentre os próprios pares. Apesar das 
dificuldades, o MMC me mostrou o quanto é importante seguir nessa luta e se reafirmar enquanto mulheres.

O envolvimento político dessas mulheres em uma compreensão de totalidade da questão da violência é que lhes abre espaço para não terem nem dono em casa, nem porta-voz na rua.

O Movimento de Mulheres Camponesas tem muito a ensinar a todas e todos nós. 


\section{REFERÊNCIAS BIBLIOGRÁFICAS}

ABREU, Zina. Luta das mulheres pelo direito de voto: movimentos sufragistas na GrãBretanha e nos Estados Unidos. 2002. Disponível em: <http//repositorio.uac.pt/handle/10400.3/380>. Acesso em: 10 dez. 2014.

ANDRADES, Thiago Oliveira de; GANIMI, Rosângela Nasser. Revolução verde e a $\begin{array}{lll}\text { apropriação } & \text { capitalista. } & \text { Disponível: }\end{array}$ $<$ http//www.cesjf.br/revistas/cesrevista/edicoes/2007/revolucao_verde.pdf >. Acesso em: 11 dez. 2014.

ARONOVICH, Lola. "Misoginia, machismo. E Rihanna espancada por Chris Brown". Blog Escreva Lola, escreva, 12 de fevereiro de 2009. Disponível em: $<$ http://escre valolaescre va.blogspot.com.br/2009/02/misoginia-machismo-e-rihannaespancada.html . Acesso em: 30 jun. 2014.

BEAUVOIR, Simone de. O Segundo Sexo - a experiência vivida. 4. ed. Tradução de Sérgio Milliet. São Paulo: Difusão Europeia do Livro: 1970a.

O Segundo Sexo - fatos e mitos. 4. ed. Tradução de Sérgio Milliet. São Paulo: Difusão Europeia do Livro: $1970 b$.

BOBBIO, Norberto. Era dos direitos. Elsevier Brasil, 2004.

BRASIL. Decreto-lei n. 2.848, de 7 de setembro de 1940. Disponível em: $<$ http//www.planalto.gov.br/ccivil_03/Decreto-Lei/De12848.htm>. Acesso em: 11 mar. 2015.

. Lei n. 13.019, de 31 de julho de 2014. Disponível em: em <http//www.planalto.gov.br/ccivil_03/_Ato2011-2014/2014/Lei/L13019.htm〉. Acesso em: 18 mar. 2015.

BRASIL 247. "R7 pisa na bola em patrulha a corpo de Fernanda Gentil, que está grávida". Brasil 247, de 21 de janeiro de 2015. Disponível em: <http:/www.brasil247.com/pt/247/midiatech/167381/R7-pisa-na-bola-em-patrulha-acorpode-Fernanda-Gentil-que-está-grávida.htm>. Acesso em: 20 mar. 2015.

BUTLER, Judith. Fundamentos contingentes. Cadernos Pagu, v. 11, p. 11-42, 1998. Disponível em: <http//www.bibliotecadigital. unicamp.br/document/?code=51196>. Acesso em: $1^{\circ}$ nov. 2014. 
CARLOS, Daiane dos Santos; CONTE, Isaura Isabel. Oito de março de 2006: em defesa da vida, mais um marco na luta das mulheres camponesas. In: PALUDO, Conceição (Org). Mulheres: resistência e luta em defesa da vida. São Leopoldo: CEBI, 2009.

CARVALHO, José Murilo de. Cidadania no Brasil. O longo Caminho. 3. ed. Rio de Janeiro: Civilização Brasileira, 2002.

CASTRO-GÓMEZ, Santiago; GROSFOGUEL, Ramón (Ed.). El giro decolonial: reflexiones para una diversidad epistémica más allá del capitalismo global. Siglo del Hombre Editores, 2007. em: $<$ http $/ /$ www. unsa.edu.ar/histocat/hamoderna/grosfoguelcastrogomez.pdf $>$. Acesso em: 10 dez. 2014

CASTRO, Edna Castro; MOURA, Edila A. F.; MAIA, Maria Lucia Sá Maia (Orgs.). Industrialização e Grandes Projetos: Desorganização e Reorganização do Espaço. Belém: Gráfica e Editora da UFPA, 1995.

CINELLI, Catiane; JAHN, Elisiane de Fatima. A constituição de identidades camponesa e feminista no Movimento de Mulheres Camponesas. Revista Espaço Acadêmico, n. 117, ano X, fev. de 2011.

CONTE, Isaura Isabel. Mulheres Camponesas em Luta: Resistência, libertação e empoderamento. 2011. 157f. Dissertação (Mestrado em Educação nas Ciências) - UNIJUI Programa de Pós Graduação em Educação nas Ciências. UNIJUI, Ijuí, 2011a.

O que entendemos por Soberania Alimentar? In: ; ANZILAGO, Julciane (Org.). Camponesas promovendo soberania alimentar com a diversidade brasileira. Passo Fundo, RS: Associação Nacional de Mulheres Camponesas - ANMC, 2011b.

; MARTINS, Mariane Denise; DARON, Vanderléia Pulga. Movimento de Mulheres Camponesas: na luta a constituição de uma identidade feminista, popular e camponesa. In: PALUDO, Conceição (Org.). Mulheres: resistência e luta em defesa da vida. São Leopoldo: CEBI, 2009.

COSTA, Ana Alice Alcântara; SARDENBERG, Cecilia Maria Bacellar. Teoria e práxis feministas na academia: os núcleos de estudos sobre a mulher nas universidades brasileiras. Revista Estudos feministas, Florianópolis, número especial, p. 387-400, 1994.

DELPHY, Cristine. Un féminisme matérialiste est possible. 1975. Nouvelles Questions Féministes, n. 4, pp. 50-86, 1982. Disponível em: <http//www.feministes-radicales.org/wp- 
content/uploads/2010/11/Christine-Delphy-Un-féminisme-matérialiste-est-possible.pdf $>$.

Acesso em: 12 set. 2014.

DEL PRIORE, Mary (Org.); PINSK, Carla Bassanezi (Coord.). Histórias das Mulheres no Brasil. 9. ed. $2^{\text {a }}$ reimpressão. São Paulo: Contexto, 2010.

DESIDÉRIO, Mariana. " $28 \%$ das mulheres assassinadas no país morrem em casa”. Folha de $S$. Paulo, São Paulo, 08 de agosto de 2014. Disponível em: $<\mathrm{http}: / / \mathrm{m}$. folha.uol.com.br/cotidiano/956164-28-das-mulheres-assassinad as-no-pais- morremem-casa.html>. Acesso em: 10 dez. 2014

DUSSEL, Enrique. 1492: o encobrimento do outro. A origem do mito da modernidade. Petrópolis: Editora Vozes, 1993.

ESCRIVÃO FILHO, Antonio Sergio; FRIGO, Darci. A luta por direitos e a criminalização dos movimentos sociais: a qual Estado de Direito serve o sistema de justiça? Publicado em 10 de maio de 2010. Disponível em: <http:/terradedireitos.org.br/2010/05/10/a-luta-por-direitos-e-acriminalizacao-dos-movimentos-sociais-a-qual-estado-de-direito-serve-o-sistema-dejustica/>. Acesso em: 26 mar. 2015.

FALQUET, Jules. Nouvelles questions féministes: 22 años profundizando en una visión feminista, radical, materialista y anti-esencialista. Rev. Estud. Fem., Florianópolis, v. 12, n. spe, dez. $2004 . \quad$ Disponível em: $<$ http://www.scielo.br/scielo.php?script=sci_arttext\&pid=S0104-

026X2004000300006\&lng=en\&nrm=iso>. Acesso em: 31 mar. 2014.

FEITOZA, Pedro. O Direito como legítima organização social da liberdade: a teoria dialética de Roberto Lyra Filho. 2014. Dissertação (Mestrado em Direito) - Universidade de Brasília, Brasília, 2014.

FONSECA, Cláudia. Ser mulher, mãe e pobre. In: DEL PRIORE, Mary (Org.); PINSK, Carla Bassanezi (Coord.). História das Mulheres no Brasil. 9. ed. $2^{\mathrm{a}}$ reimpressão. São Paulo: Contexto, 2010.

FOUCAULT, Michel. Vigiar e punir: nascimento da prisão. Tradução de Raquel Ramalhete. Petrópolis: Vozes, 1987.

FREIRE, Paulo. Pedagogia do Oprimido. 42. ed. Rio de Janeiro: Paz e Terra, 2005.

FURTADO, Celso. Formação Econômica do Brasil. 23. ed. São Paulo: Editora Nacional, 1989. 
GUISOLPHI, Anderson José. As Marchas da Familia com Deus pela Liberdade: ideologias e práticas católicas no golpe militar de 1964. Revista Cadernos do CEOM, v. 22, n. 31, p. 453458, 2010.2 Disponível em: <http//bell. unochapeco.edu.br/revistas/index.php/rcc/article/viewFile/559/381 >. Acesso em: 20 mar. 2015.

GONÇALVES, Renata. Sem pão e sem rosas: do feminismo marxista impulsionado pelo Maio de 1968 ao academicismo de gênero. Lutas Sociais, n. 21/22, p. 98-110, 2009.

GUILLAUMIN, Colette. Práctica del poder e idea de Naturaleza. In: CURIEL, Ochy; FALQUET, Jules. El patriarcado al desnudo: tres femenistas materialistas: Colette Guillaumin - Paola Tabet - Nicole Claude Mathieu. Buenos Aires: Brecha Lesbica, edición en castellano, 2005. Disponível em: <https://julesfalquet.files.wordpress.com/2010/05/el-patriarcado-aldesnudo-tres-feministas-materialistas2.pdf>. Acesso em: ago. 2014.

GUIMARAES, Antonio Sérgio Alfredo. Democracia racial. São Paulo: USP, 2003. Disponível em: 〈http $/ /$ www.fflch. usp.br/sociologia/asag/Democracia\%20racial.pdf >. Acesso em: $1^{\circ}$ mar. 2015.

IANNI, Octávio. Ditadura e agricultura: O desenvolvimento do capitalismo na Amazônia, 1964-1978. Rio de janeiro: Civilização Brasileira, 1979.

KERGOAT, Danièle. Dinâmica e consubstancialidade das relações sociais. Novos estud. CEBRAP, São Paulo, n. 86, mar. 2010. Disponível em: $<$ http://www.scielo.br/scielo.php?script=sci_arttext\&pid=S0101 -

33002010000100005\&lng=en\&nrm=iso>. Acesso: 31 mar. 2015.

LERNER, Gerda. La creación del patriarcado. Disponível em: $<$ http $/ /$ www.antimilitaristas.org/IMG/pdf/la_creacion_del_patriarcado_-_gerda_lerner2.pdf $>$. Acesso em: $10 \mathrm{dez} .2013$.

LYRA FILHO, Roberto. O que é Direito. 11. ed. São Paulo: Brasiliense, 2005.

Sociologia e direito: textos básicos para a disciplina de sociologia jurídica. 2. ed. atual. Organizadores: Cláudio Souto e Joaquim Falcão. São Paulo: Pioneira, 1999. 1983a.

Karl, meu amigo: diálogo com Marx sobre o direito. Porto Alegre: Fabris Editor, Humanismo dialético. Porto Alegre: Safe, 1983b. 
Para uma Visão Dialética do Direito. Direito e avesso: boletim da Nova Escola Jurídica Brasileira, Brasília, ano II, n. 3, 1983c, p. 15-103.

Direito do capital e direito do trabalho. Porto Alegre: Fabris Editor, 1982.

JARH, Elisiane de Fátima; PEREIRA, Nancy Cardoso. Todas as Vidas... Todas as Vias Camponesas! In: PALUDO, Conceição (Org.). Mulheres, resistência e luta em defesa da vida. São Leopoldo: CEBI, 2009.

LOWY, Michael. As aventuras de Karl Marx contra o Barão de Munchhausen: marxis mo e positivismo na sociologia do conhecimento. 5. ed. São Paulo: Busca Vida, 1991.

MARIANO, Silvana Aparecida. O sujeito do feminismo e o pós-estruturalismo. Rev. Estud. Fem., Florianópolis, v. 13, n. 3, dez. 2005. Disponível em: $<$ http://www.scielo.br/scielo.php?script=sci_arttext\&pid=S0104-

026X2005000300002\&lng=en\&nrm=is>o>. Acesso em: 6 set. 2014.

MARX, Karl; ENGELS, Friedrich. A ideologia alemã. São Paulo: Boitempo Editorial, 2007.

MATHIEU, Nicole-Claude. Identidad sexua/sexuada/ de sexo? Tres modos de conceptualización de la relación entre sexo y género. In: CURIEL, Ochy; FALQUET, Jules. El patriarcado al desnudo: tres femenistas materialistas: Colette Guillaumin - Paola Tabet Nicole Claude Mathieu. Buenos Aires: Brecha Lesbica, edición en castellano, 2005. Disponíve 1 em: $\quad<$ https://julesfalquet.files. wordpress.com/2010/05/el-patriarcado-al-desnudo-tresfeministas-materialistas2.pdf $>$. Acesso em: 10 ago. 2014.

MENDES, Soraia da Rosa. (Re)pensando a criminologia: reflexões sobre um novo paradigma desde a epistemologia feminista. 2012. 284 f. Tese (Doutorado em Direito) - Universidade de Brasilia, Brasilia, 2012. Disponível em: $<$ http://repositorio.unb.br/bitstream/10482/11867/1/2012_SoraiadaRosaMendes.pdf $>$. Acesso em: 27 nov. 2014.

MENEZES, Fernando Dominience. Enunciados sobre o futuro: ditadura militar, Transamazônica e a construção do "Brasil grande". 2007. 147 f. Dissertação (Mestrado em História) - Universidade de Brasîlia, Brasília, 2007. Disponível em: $<$ http//repositorio.unb.br/bitstream/10482/2510/1/2007_FernandoDominienceMenezes.PDF> . Acesso em: 30 dez. 2014.

MICHEL Foucault par lui même. Direção de Philippe Calderon. (2003), produzido por Françoise Castro, 2003. Disponível em: <http://www.youtube.com/watch?v=Xkn31sjh4 To>. Acesso em: 27 nov. 2014. 
MORAES, Maria Lygia Quartim de. Marxismo e feminismo: afinidades e diferenças. Revista Crítica Marxista, São Paulo, n. 11, 2000.

MOVIMENTO DE MULHERES CAMPONESAS. "Quem Somos". Disponível em: <http://www.mmcbrasil.com.br/site/node/43>. Acesso em: 5 set. 2014.

. "História". Disponível em: <http://www.mmcbrasil.com.br>. Acesso em: 5 set. 2014.

2015.

. "Organização". Disponível em: <http//www.mmcbrasil.com.br>. Acesso em: 10 fev.

Campanha "Solidariedade às mulheres escalpeladas MMC". Disponível em: <https://www.youtube.com/watch?v=GsvKSqW0hQg>. Acesso em: 30 ago. 2014.

NAVAZ, Liliana Suárez; CASTILlO, Rosalva Aída Hernández (Ed.). Descolonizando el feminismo: teorías y prácticas desde los márgenes. Madrid: Ed. Cátedra, 2008.

PAULILO, Maria Ignez S. Intelectuais e militantes e as possibilidades de diálogo. Revista Estudos Feministas, Florianópolis, 16(3), p. 927-940, set./dez. 2010. Disponível em: <https://periodicos.ufsc.br/index.php/ref/article/view/S0104-026X2010000300017/17759>. Acesso em: 10 dez. 2014.

; SILVA, Cristiani Bereta da. Memórias de Luci Choinaski: histórias e lutas pelos direitos das mulheres camponesas. In: SCOTT, Parry; CORDEIRO, Rosineide; MENEZES, Marilda (Orgs.). Gênero e geração em contextos rurais. Ilha de Santa Catarina: Ed. Mulheres, 2010.

PEDRO, Joana Maria. Mulheres do Sul. In: DEL PRIORE, Mary (Org.); PINSK, Carla Bassanezi (Coord.). História das Mulheres no Brasil. 9. ed. 2. Reimpressão. São Paulo: Contexto, 2010.

PIOVESAN, Flavia. Direitos humanos e o Direito Constitucional Internacional. 10. ed. rev. e ampl. São Paulo: Saraiva, 2009.

PRIORE, Mary Del. Ao Sul do Corpo: Condição feminina, maternidades e mentalidades no Brasil Colônia. Rio de Janeiro: José Olympio; Brasilia: Edunb, 1993.

SAFFIOTI, Heleieth. Gênero e Patriarcado: a necessidade da violência. In: CASTILLO MARTÍN, Márcia; OLIVEIRA, Suely de (Orgs.). Marcadas a ferro. Brasîlia: Secretaria Especial de Políticas Para as Mulheres, 2005. 
SANTOS, Boaventura de Sousa. A Crítica da Razão Indolente. Contra o Desperdício da Experiência. 4. ed. São Paulo: Cortez, 2002.

SCAVONE, Lucila. Estudos de gênero e feminista: um campo científico? XXXI Encontro Anual da ANPOCS, 2007. Disponível em: $<$ http $/ /$ portal.anpocs.org/portal/index.php?option=com_docman\&task=doc_view\&gid=2952 \&Itemid=231>. Acesso em: 10 dez. 2014.

SCOTT, Parry; CORDEIRO, Rosineide; MENEZES, Marilda (Orgs.). Gênero e geração em contextos rurais. Florianópolis: Editora Mulheres, 2010. Disponível em: $<$ https://www.ufpe.br/fagesufpe/images/documentos/Livros_Fages/genero\%20e\%20gera_o\% 20em\%20contextos\%20rurais.pdf $>$. Acesso em: 20 mar. 2015.

SCOTT, Joan. Gênero: uma categoria útil de análise histórica. Educação e realidade, v. 20, n. 2, 1991. Tradução de Christine Rufino Dabat e Maria Betânia Ávila. Disponível em: <http//disciplinas.stoa.usp.br/pluginfile.php/185058/mod_resource/content/2/Gênero-

Joan\%20Scott.pdf>. Acesso em: 10 ago. 2014.

Género: ¿Todavía una categoría útil para el análisis? Revista La manzana de la discordia, v. 6, n. 1, jan./jun. 2011, p. 95-101. Disponível em $\left\langle\right.$ http $/ /$ manzanadiscordia. univalle.edu.co/volumenes/articulos/V6N1/art9.pdf $>$. Acesso em: $1^{\circ}$ set. 2014.

SECRETARIA DE POLÍTICAS PARA AS MULHERES DA PRESIDÊNCIA DA REPÚBLICA. Mulheres do campo e da floresta: Diretrizes e ações nacionais. Brasilia, 2011. (Coleção Enfrentamento à violência contra as mulheres). Disponível em: $<$ http./www.spm.gov.br/sobre/publicacoes/publicacoes/2011/campo-e-floresta>. Acesso em :18 mar. 2015.

Consenso de Brasília. XI Conferência Regional sobre a Mulher da América Latina e Caribe. Brasilia, outubro de 2013. Disponível em: $<$ http $/ /$ www.cepal.org/12conferenciamujer/noticias/paginas/7/49917/Informe_Brasil__Consenso_de_Brasilia.pdf $>$. Acesso em: 3 nov. 2014.

SILVA, Carmen (Org.). Experiências em Pedagogia Feminista. Recife: SOS Corpo - Instituto Feminista para a Democracia, 2010a.

STEDILE, João Pedro (Org.). A questão Agrária no Brasil. História e natureza das Ligas Camponesas - 1954-1964. São Paulo: Expressão Popular, 2006. 
SOIHET, Raquel. Mulheres Pobres e Violência no Brasil Urbano. In: DEL PRIORE, Mary (Org.); PINSK, Carla Bassanezi (Coord.). História das Mulheres no Brasil. 9. ed. 2. reimpressão. São Paulo: Contexto, 2010.

TODOROV, Tzvetan. A conquista da América: a questão do outro. São Paulo: Martins Fontes, 1982.

VIA CAMPESINA. As camponesas e os camponeses da Via Campesina dizem: Basta de violência contra as mulheres. Campanha Internacional da Via Campesina. Brasilia, julho de 2012. Disponível em: 〈www.mmcbrasil.com.br/site/materiais/cartilha_vc_sudamerica.pdf $>$. Acesso em: 8 set. 2014.

WOLKMER, Antonio Carlos. Pluralismo Jurídico: fundamentos de uma nova cultura no Direito. 3. ed. São Paulo: Alfa-Omega, 2001.

YOUNG, Íris. A imparcialidade e o público cívico. Feminismo como crítica da Modernidade, 1987. 